\title{
Highly Valuable Polyunsaturated Fatty Acids from Microalgae: Strategies to Improve Their Yields and Their Potential Exploitation in Aquaculture
}

\author{
Anna Santin ${ }^{1}$ (D), Monia Teresa Russo ${ }^{1}$, Maria Immacolata Ferrante ${ }^{1, *(D)}$, Sergio Balzano ${ }^{1,2}$ (D), Ida Orefice ${ }^{1}$ (D) \\ and Angela Sardo ${ }^{1,3, *}$ \\ 1 Stazione Zoologica Anton Dohrn, Villa Comunale, 80121 Naples, Italy; anna.santin@szn.it (A.S.); \\ monia.russo@szn.it (M.T.R.); sergio.balzano@szn.it (S.B.); ida.orefice@szn.it (I.O.) \\ 2 Department of Marine Microbiology and Biogeochemistry, Netherland Institute for Sea Research, \\ Landsdiep 4, 1793 AB Texel, The Netherlands \\ 3 Istituto di Scienze Applicate e Sistemi Intelligenti "Eduardo Caianiello", Via Campi Flegrei 34, \\ 80078 Pozzuoli, Italy \\ * Correspondence: mariella.ferrante@szn.it (M.I.F.); angela.sardo@szn.it (A.S.)
}

check for

updates

Citation: Santin, A.; Russo, M.T.; Ferrante, M.I.; Balzano, S.; Orefice, I.; Sardo, A. Highly Valuable

Polyunsaturated Fatty Acids from Microalgae: Strategies to Improve Their Yields and Their Potential Exploitation in Aquaculture. Molecules 2021, 26, 7697. https:// doi.org/10.3390/molecules26247697

Academic Editor: Cédric Delattre

Received: 29 November 2021 Accepted: 15 December 2021 Published: 20 December 2021

Publisher's Note: MDPI stays neutral with regard to jurisdictional claims in published maps and institutional affiliations.

Copyright: (c) 2021 by the authors. Licensee MDPI, Basel, Switzerland. This article is an open access article distributed under the terms and conditions of the Creative Commons Attribution (CC BY) license (https:// creativecommons.org/licenses/by/ $4.0 /)$.

\begin{abstract}
Microalgae have a great potential for the production of healthy food and feed supplements. Their ability to convert carbon into high-value compounds and to be cultured in large scale without interfering with crop cultivation makes these photosynthetic microorganisms promising for the sustainable production of lipids. In particular, microalgae represent an alternative source of polyunsaturated fatty acids (PUFAs), whose consumption is related to various health benefits for humans and animals. In recent years, several strategies to improve PUFAs' production in microalgae have been investigated. Such strategies include selecting the best performing species and strains and the optimization of culturing conditions, with special emphasis on the different cultivation systems and the effect of different abiotic factors on PUFAs' accumulation in microalgae. Moreover, developments and results obtained through the most modern genetic and metabolic engineering techniques are described, focusing on the strategies that lead to an increased lipid production or an altered PUFAs' profile. Additionally, we provide an overview of biotechnological applications of PUFAs derived from microalgae as safe and sustainable organisms, such as aquafeed and food ingredients, and of the main techniques (and their related issues) for PUFAs' extraction and purification from microalgal biomass.
\end{abstract}

Keywords: microalgae; polyunsaturated fatty acids (PUFAs); genetic engineering; growth conditions; marketable PUFAs; sustainable processes

\section{Introduction}

Microalgae exploitability has received great attention for different purposes during the last decades. These microorganisms have been, indeed, largely investigated as a source of biofuels [1,2], bioactive components for cosmetic and cosmeceutical formulations [3,4], and high-value pharmaceuticals [5]. Microalgae appear also suitable as fertilizers [6] because of their water-binding capacity and their ability to release macro- and micronutrients to the surrounding soils at low rates [7]. They are currently being investigated for aquatic environments' bioremediation, known as phycoremediation [8,9]. Furthermore, microalgae have been studied because of their potential for the production of healthy food and feed supplements [10,11]. Microalgal biomass can be used, indeed, as raw material for thirdgeneration biorefinery processes [12], which foresee its conversion in a wide spectrum of marketable products and energies, minimizing costs and waste production. To date, various companies have adopted this approach and are able grow microalgae at pilot scale and to produce different kinds of commodities (mainly energy carriers, pigments, 
and polyunsaturated fatty acids) from the same biomass, for various biotechnological sectors [13-15].

Microalgae-based technology exhibits several advantages, which overcome numerous constraints related to the cultivation of other organisms and/or natural sources. They do not require arable land and, thus, do not compete with agricultural crops for space [16] and exhibit growth rates higher than those observed in terrestrial plants [17]. Besides, microalgal growth could be considered an environmentally safe process, not requiring herbicides and pesticides for maintenance. Their growth can be directly related to carbon dioxide fixation $[18,19]$ and can also contribute to the reduction of other greenhouse gases in the atmosphere such as nitrogen and sulfur oxides [20]. Moreover, differently from lignocellulosic materials, microalgal biomass does not require cost- and time-consuming pre-treatments for the extraction of biomolecules [12] and lends itself to different extraction techniques, some of which minimize or avoid the use of solvents [21].

Polyunsaturated fatty acids (PUFAs) are fatty acids (FAs) containing two or more double bonds in their acyl chain. PUFAs are classified into two main groups on the basis of the length of their carbon backbone: short chain polyunsaturated fatty acids (SC-PUFAs), with 16 or 18 carbon atoms, and long-chain polyunsaturated fatty acids (LCPUFAs) with more than 18 carbons (the Greek letter $\omega$ in PUFAs' nomenclature indicates the first position of the double bond from the terminal carbon). It is common knowledge that PUFA consumption is related to various health benefits for humans, as well as the improvement of metabolic rates, the regulation of blood pressure and glucose level, and the protection against numerous diseases, including some types of cancer [22]. Clinical and epidemiological studies have shown that an eicosapentaenoic acid (EPA- $\left.\mathrm{C}_{20: 5} \omega 3\right)$-rich diet contributes to minimizing risks of cardiovascular diseases [23,24]. Docosahexaenoic acid $\left(\right.$ DHA- $\left.C_{22: 6} \omega 3\right)$ and arachidonic acid (AA- $\left.\mathrm{C}_{20: 4} \omega 6\right)$ are important to avoid impairments in infant brain development and cognitive deficiency [25-27]. EPA and DHA may also lower the risks of obesity in both humans and animals [28] and can prevent chronic inflammatory diseases [29]. Humans, as other mammals, are unable or poorly able to synthesize some essential PUFAs, such as linoleic acid (LA- $\left.\mathrm{C}_{18: 2} \omega 6\right)$ and $\alpha$-linolenic acid (ALA- $\mathrm{C}_{18: 3} \omega 3$ ), which are precursors of AA and DHA, respectively. Therefore, a direct uptake of these compounds from external sources is necessary. These sources include aquatic organisms (fish, molluscs, and crustaceans), animal-derived commodities (meat, milk, eggs), fungi, bacteria, and vegetable sources, such as some plants and microalgae [30]. The main microbial sources, which are able to produce highly valuable lipids for nutraceutical purposes, are summarised in Figure 1, while the main PUFAs, which may provide health benefits, are summarized in Table 1.

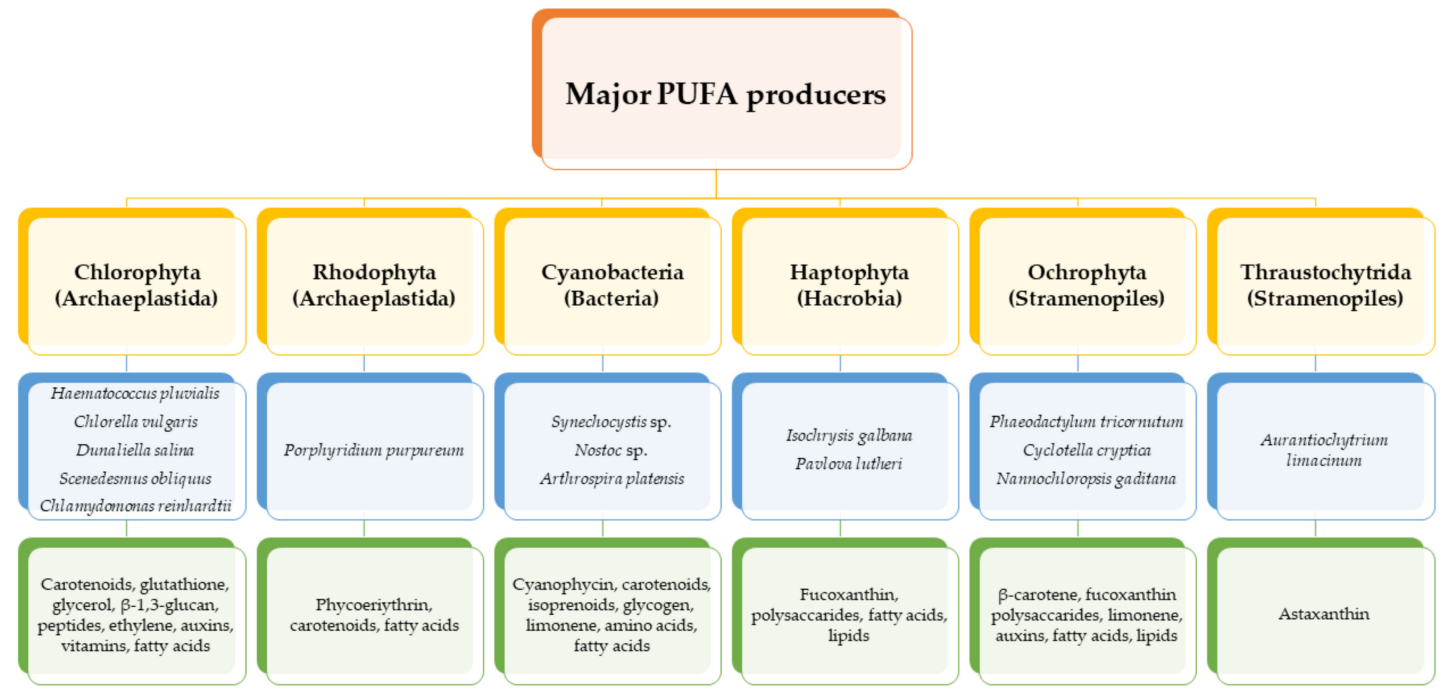

Figure 1. Main polyunsaturated fatty acid (PUFA)-producing microorganisms and associated high-value products. 
Table 1. Main polyunsaturated fatty acids (PUFAs): common and IUPAC names, acronyms, and structural formulas.

\begin{tabular}{|c|c|c|c|}
\hline Fatty Acid & Acronym & IUPAC Name & Structure \\
\hline $\begin{array}{l}\text { Palmitic acid } \\
\qquad\left(\mathrm{C}_{16: 0}\right)\end{array}$ & PA & Hexadecanoic acid & \\
\hline $\begin{array}{l}\text { Stearic acid } \\
\qquad\left(\mathrm{C}_{18: 0}\right)\end{array}$ & SA & Octadecanoic acid & \\
\hline $\begin{array}{l}\text { Oleic acid } \\
\left(\mathrm{C}_{18: 1} \omega 9\right)\end{array}$ & OA & (9Z)-Octadec-9-enoic acid & \\
\hline Linoleic acid $\left(C_{18: 2} \omega 6\right)$ & LA & $(9 Z, 12 Z)$-Octadeca-9,12-dienoic acid & \\
\hline $\begin{array}{l}\alpha \text {-linolenic acid } \\
\quad\left(C_{18: 3} \omega 3\right)\end{array}$ & ALA & $\begin{array}{c}(9 \mathrm{Z}, 12 \mathrm{Z}, 15 \mathrm{Z}) \text {-Octadeca-9,12,15- } \\
\text { trienoic } \\
\text { acid }\end{array}$ & \\
\hline $\begin{array}{l}\gamma \text {-linolenic acid } \\
\quad\left(C_{18: 3} \omega 6\right)\end{array}$ & GLA & $\begin{array}{l}\text { (6Z,9Z,12Z)-Octadeca-6,9,12-trienoic } \\
\text { acid }\end{array}$ & \\
\hline $\begin{array}{l}\text { Eicosatetraenoic acid } \\
\qquad\left(C_{20: 4} \omega 3\right)\end{array}$ & ETA & $\begin{array}{l}(8 Z, 11 Z, 14 Z, 17 Z)-I c o s a-8,11,14,17- \\
\text { tetraenoic acid }\end{array}$ & \\
\hline $\begin{array}{l}\text { Dihomo- } \gamma \text {-linoleic acid } \\
\qquad\left(C_{20: 3} \omega 6\right)\end{array}$ & DHGLA & $\begin{array}{l}\text { (8Z,11Z,14Z)-Icosa-8,11,14-trienoic } \\
\text { acid }\end{array}$ & \\
\hline $\begin{array}{l}\text { Arachidonic } \\
\text { Acid } \\
\left(C_{20: 4} \omega 6\right)\end{array}$ & AA & $\begin{array}{c}(5 \mathrm{Z}, 8 \mathrm{Z}, 11 \mathrm{Z}, 14 \mathrm{Z})-\mathrm{Icosa}-5,8,11,14- \\
\text { tetraenoic } \\
\text { acid }\end{array}$ & \\
\hline $\begin{array}{l}\text { Eicosapentaenoic acid } \\
\left(C_{20: 5} \omega 3\right)\end{array}$ & EPA & $\begin{array}{c}\text { (5Z,8Z,11Z,14Z,17Z)-Icosa- } \\
5,8,11,14,17 \text {-pentaenoic } \\
\text { acid }\end{array}$ & \\
\hline $\begin{array}{l}\text { Docosatetraenoic acid } \\
\qquad\left(C_{22: 4} \omega 6\right)\end{array}$ & DTA & $\begin{array}{c}(7 Z, 10 Z, 13 Z, 16 Z)-D o c o s a-7,10,13,16- \\
\text { tetraenoic } \\
\text { acid }\end{array}$ & \\
\hline $\begin{array}{l}\text { Docosahexaenoic acid } \\
\qquad\left(C_{22: 6} \omega 3\right)\end{array}$ & DHA & $\begin{array}{c}\text { (4Z,7Z,10Z,13Z,16Z,19Z)-Docosa- } \\
4,7,10,13,16,19 \text {-hexaenoic } \\
\text { acid }\end{array}$ & \\
\hline $\begin{array}{l}\text { Docosapentaenoic acid } \\
\qquad\left(C_{22: 5}(13)\right.\end{array}$ & DPA & $\begin{array}{c}\text { (7Z,10Z,13Z,16Z,19Z)-Docosa- } \\
\text { 7,10,13,16,19-pentaenoic } \\
\text { acid }\end{array}$ & \\
\hline
\end{tabular}

The use of vegetal sources of oils is also considered as a useful means to limit the total use of fishmeal in aquaculture. Due to the high commercial demand, and because of the competition from other sectors such as the pharmaceutical trade [31], fish-based commodities are, actually, very expensive. Moreover, aquaculture accounts for a large portion of the global demand for fish oil, leading to the paradox that fish oil is used for fish breeding. Aside from being uneconomic, fish oil production is also considered detrimental for the environment, since its increasing demand leads to a fast decline of natural fish stocks. 
Finally, vegetal alternatives to fish oil could significantly reduce risks of incorporating aquatic pollutants (carcinogen contaminants, heavy metals) and/or antibiotics used in fish farms and the occurrence of unpleasant odours and tastes.

Some microalgae-derived products are currently available on the market. Algal biochemical composition, and, subsequently, the yields of their high-value lipids can be tuned through regulation of growth conditions and/or genetic transformations aimed at modifying algal metabolism. Short-chain FAs with lower pureness and low unsaturation degrees, which are inadequate for the production of food or feed commodities and for pharmaceutical purposes, are only useful for biodiesel production. However, the high cost of microalgal biofuel compared to that of fossil sources still prevents its production. Conversely, different industrial plants producing food or feed supplements are spreading worldwide, even if there are still few species that have found a market. This review was aimed at describing the current knowledge of microalgae-derived oils with nutritional value, the strategies to improve their yields, and the main bottlenecks related to large-scale production by the food and feed industries.

\section{Modulation of Growth Conditions to Enhance the Production of PUFAs}

Lipid metabolism in microalgae can be controlled by modulating growth parameters, such as temperature, light, partial pressure of carbon dioxide $\left(\mathrm{CO}_{2}\right)$, and nutrient supply. Optimization of such parameters can increase growth rates and, thus, biomass and lipid productivities. Changing the biochemical composition of microalgae by tuning physical and nutritional parameters leads to similar changes in the biochemical composition of microalgae-fed organisms, both at the larval and adult stages [32,33].

\subsection{Temperature}

Temperature can be considered a useful factor to select the most suitable strains for PUFA-rich polar lipid production [34]. Temperature shifts, indeed, play a key role in adjusting membrane fluidity: Generally, lower temperatures enhance the unsaturation degrees of FAs, and vice versa. By contrast, growth rates can decrease at decreasing temperature, leading to the decline in the productivity of all lipids including PUFAs; the temperature conditions yielding the greatest PUFA productivity are usually species specific.

The effect of low $\left(\leq 20^{\circ} \mathrm{C}\right)$ temperatures was evaluated on the oleaginous microalga Scenedesmus obtusus grown in outdoor plants. A two-fold increase in PUFAs with respect to indoor cultures, in which higher temperature values were constantly maintained, was detected [35]. This strategy was found to be effective also in diatom species: A drastic temperature decrease by 9 degrees (from 20 to $11^{\circ} \mathrm{C}$ ) stimulated PUFAs' production in Cylindrotheca closterium during the stationary phase [36]. PUFAs were also found to reach high proportions (i.e., ca. $40 \%$ ) of the total FAs in Odontella aurita cultured at $8{ }^{\circ} \mathrm{C}$, compared with treatments at $16{ }^{\circ} \mathrm{C}$ and $24{ }^{\circ} \mathrm{C}$, in which the proportion of PUFAs was $28-31 \%$ and $6-26 \%$, respectively [37].

The concentration of PUFAs generally decreases at increasing temperatures. For example, EPA accumulation declined markedly with the increase of temperature also in the red alga Porphirium purpureum [38]. A significant decrease of EPA, DHA, and other PUFAs with increasing temperature (from 15 to $25^{\circ} \mathrm{C}$ ) was also observed in the diatom Phaeodactylum tricornutum [39].

\subsection{Nutrients}

Both culture media composition (e.g., nutrient concentration and composition) and growth phase (since nutrients tend to decrease over time during algal growth) can affect lipid metabolism. Generally, the concentration of unsaturated fatty acids (UFAs) is higher during the exponential phase and tends to decrease in aged cultures. This happens because plastidial membranes, which are actively biosynthesised during the exponential phase, contain larger proportions of UFAs compared to other cellular membranes as well as lipid droplets [40]. 
To our knowledge, nitrogen $(\mathrm{N})$ limitation or depletion is the most common culturing manipulation used to enhance lipid production, although it usually causes a reduction in biomass and lipid yields [41-43]. Two-stage cultivation systems-the first one of nutrient replenishment, to increase biomass, and the second one with low or null N supply, to enhance lipid production-can be effective to overcome this problem [2,18] and are correlated to a strong increase of the neutral lipid fraction (especially triacylglycerols (TAGs)). For example, two-stage cultivation was found to be effective in increasing lipid concentration in Nannochloropsis spp. [44,45]. Since PUFAs in phospholipids (PLs) are nutritionally more available than those esterified in TAGs [46], an efficient production process might be achieved by maximising the proportion of PLs within cells and that of PUFAs within PLs. This can be usually obtained by culturing microalgae under $\mathrm{N}$ limitation rather than incubating microalgal biomass in N-depleted media. In Isochrysis aff. galbana (clone T-Iso) and in Nannochloropsis oceanica, the proportion of EPA in PLs was, indeed, lower under total depletion of $\mathrm{N}$, and a similar trend was observed for DHA in T-Iso [47]. N limitation likely led to a decrease in the production rates of $\omega-3$ PUFA, stimulating TAGs' accumulation $[39,48]$. Similar results were obtained for P. purpureum, where EPA were mostly concentrated under $\mathrm{N}$ replenishment than in the stationary phase, when an active cell division, and, thus, membrane lipid accumulation were still in progress [49].

Phosphorus $(\mathrm{P})$ limitation triggered an increase in the concentration of UFAs with respect to the total FAs, since $\mathrm{P}$ depletion stimulated the activity of $\Delta 6$-desaturase and, thus, conversion from palmitic acid (PA-C $16: 0)$ to LA acid. Moreover, stimulation of the $\omega-6$ pathway and inhibition of the enzyme $\Delta-17$ desaturase under low $\mathrm{P}$ concentration selectively promoted the biosynthesis of AA, to the detriment of the EPA pool [50]. Similar results were obtained with the freshwater eustigmatophyte Monodus subterraneus, where EPA and LC-PUFAs were drastically reduced under $\mathrm{P}\left(\mathrm{K}_{2} \mathrm{HPO}_{4}\right)$ limitation in a dosedependent way [51].

Silicon (Si) limitation seems to affect negatively PUFAs' production in diatoms [52] and is likely to be more effective for the accumulation of neutral lipids for biofuel production, since oils with little PUFA content are highly suitable for biofuel development [53].

The relative proportion of PUFAs over the total biomass as well as PUFA composition are dependent upon growth phase. For example, EPAs were found to be more abundant during the late stationary phase, while the DHA-to-EPA ratio (which must be comprised between 1 and 2 for larval fish feed) decreased since no increase of DHA levels in $P$. tricornutum, Thalassiosira weissflogii, Thalassiosira pseudonana, and Rhodomonas salina was observed [54].

\subsection{Salinity}

Salinity stress causes species-specific reactions in different microalgal strains. It causes variations in the biochemical composition of microalgae, leading to a decrease in the energy available both for photosynthesis and for intracellular FAs' composition changings, as a protection against osmotic stress [55]. It has been studied both in freshwater and saltwater species and generally causes changes in UFAs' concentrations and typology in algal strains when salt concentration is above or below the optimal level. High salinity stress (ca. 40), for example, triggered lipid and PUFAs' production in the green microalga Tetraselmis sp., which reached a high (16\%) percentage of PUFAs under optimal conditions of light intensity and $\mathrm{pH}$ [56]. While the proportion of lipids over the biomass tends to increase at increasing salinities, PUFA content typically decreases in Nannochloropsis spp. For example, N. oceanica UTEX2379 was found to increase its content in total FAs at increasing salinities (13 to $40 \mathrm{~g} \mathrm{~L}^{-1} \mathrm{NaCl}$ ) while EPA content peaked at $13 \mathrm{~g} \mathrm{~L}^{-1} \mathrm{NaCl}$ [44]. Similarly, MartínezRoldán et al. [57] observed a sharp increase in total lipids at 54 and $81 \mathrm{~g} \mathrm{~L}^{-1} \mathrm{NaCl}$ for $N$. oceanica CCALA804 and N. oceanica CCMP1779, which exhibited the highest content of saturated FAs when cultured at a salinity of 50 compared to 10 and 35 [58].

The freshwater green alga Golenkinia brevispicula was grown under a two-stage cultivation system, with a first phase-semicontinuous batch production in a freshwater 
medium — aimed at increasing biomass, and a second one—-batch conditions under high salinity-in which $35 \mathrm{~g} \mathrm{~L}^{-1}$ marine salts were added to the culture in order to increase both carotenoid and lipid content within microalgal biomass. Under salinity stress, PUFAs' percentage was almost halved with respect to the previous phase of nutrient replenishment, and it was likely due to a stronger regulation of membrane structure and fluidity in the semicontinuous phase, during which an active cell division was observed [59]. Conversely, the addition of $0.2 \% \mathrm{NaCl}$ in cultures of Trachydiscus minutus led to a slight increase of EPA content, but a further salinity increase $(0.8 \%)$ totally inhibited growth [60]. Nannochloropsis spp. were found to increase their lipid content when cultured at salinities higher than seawater values $[45,57]$, and the percentage of PUFAs over the total FAs typically decreases at increasing salinities [44].

Similar results were observed for the green alga Chlamydomonas reinhardtii (strain 137C), where $\mathrm{NaCl}$-induced stress determined an accumulation of saturated FAs, to the detriment of unsaturated ones, and an up-regulation of genes involved in fatty acid biosynthesis (prolyl hydroxylase domain 2-PDH2, Acetyl-CoA Carboxylase-ACCase, MAT and 3-ketoacyl-ACP-synthase-KAS2) [61].

\subsection{Irradiance}

Light intensity can affect lipid metabolism as a result of membrane biosynthesis or storage lipid accumulation in case of excessive carbon accumulation. While saturated FAs tend to increase at high light irradiance, the relative proportion of PUFAs over the dry weight decreases or does not change significantly. For example, very high irradiance (750 $\mu \mathrm{mol}$ photons $\mathrm{m}^{-2} \mathrm{~s}^{-1}$ ) increased saturated FAs in P. tricornutum with respect to lower light intensities $\left(150 \mu \mathrm{mol}\right.$ photons $\left.\mathrm{m}^{-2} \mathrm{~s}^{-1}\right)$; however, changes in the expression of genes responsible for PUFA production did not elucidate the mechanisms of their modulation [62]. These results were consistent with those obtained by Qiao et al. [39], which evaluated the effect of lower light intensities (50-150 $\mu \mathrm{mol}$ photons $\mathrm{m}^{-2} \mathrm{~s}^{-1}$ ) on P. tricornutum and found that an irradiance level of $150 \mu \mathrm{mol}$ photons $\mathrm{m}^{-2} \mathrm{~s}^{-1}$ stimulated DHA production. Similarly, N. oceanica UTEX2379 increased its content in total FAs and did not exhibit significant changes in EPA when cultured at $700 \mu \mathrm{mol}$ photons $\mathrm{m}^{-2} \mathrm{~s}^{-1}$, compared to $150 \mu \mathrm{mol}$ photons $\mathrm{m}^{-2} \mathrm{~s}^{-1}$ [44]. N. oceanica CCMP1779 also contained far greater amounts of saturated FAs at $300 \mu \mathrm{mol}$ photons $\mathrm{m}^{-2} \mathrm{~s}^{-1}$, compared to $25 \mu \mathrm{mol}$ photons $\mathrm{m}^{-2} \mathrm{~s}^{-1}$ [58].

\subsection{Autotrophic, Heterotrophic, and Mixotrophic Conditions}

Several microalgal genera, including Phaeodactylum and Scenedesmus, are obligate autotrophs, but others are able to grow in the presence of organic substrate as facultative (some Nannochloropsis, Dunaliella, and Tetraselmis species) or obligate (the dinoflagellates Crypthecodinium and Gyrodinium) heterotrophs [63,64]. Among heterotrophs, also Thraustochytrids, a fungus-like class of Stramenopiles, are considered a suitable source of DHA, which can accumulate at low temperatures and salinities [65]. Some algal species, such as Galdieria sulphuraria, showed a higher PUFA content when cultured under heterotrophic rather than phototrophic conditions, where a higher content in saturated and monounsaturated FAs was observed [66]. Similar results were obtained with the marine diatom Cyclotella cryptica, in which heterotrophic conditions (i.e., culture media enriched with glucose) were found to be effective to increase the EPA yields with respect to the autotrophic regime [67]. Production of PUFAs under photoheterotrophic conditions can be also influenced by the carbon source: Under controlled (indoor) conditions, for example, the employment of glucose was found more effective than other organic substrates (fructose, sucrose, and maltose) to stimulate PUFAs' production in Tetraselmis gracilis and Platymonas convolutae [68]. Unfortunately, glucose is also one of the more expensive carbon sources, and this can render the production of highly valuable lipids uneconomic [69-71].

Microalgae have also the ability to utilize nutrients from wastewater; this can minimize costs and water requirement and contribute to bioremediation of effluents [70]. To the best of our knowledge, only a few papers regarding highly valuable lipids for nutritional 
purposes obtained by waste-fed microalgae are available in literature. However, their efficiency depends on the strain and on waste typology. The employment of digestate (e.g., biodegradable feedstock from anaerobic digestion) as nourishment for the green alga Chlorella vulgaris, for example, was detrimental for the total lipid pool and its unsaturated fraction [71]. Conversely, a partial (25\%) replacement of the synthetic medium with industrial process waters was not inhibitory for the growth of the freshwater species Arthrospira platensis and stimulated PUFAs' (42-45\% of total lipid pool) accumulation [72]. Recent works demonstrate that alternative organic sources such as glycerol wastes can be successfully used to sustain microalgal growth of heterotrophic species (e.g., Schizochytrium sp.), improving the yields of DHA with economic and environmentally sustainable processes [73,74]. Biomass and DHA yields could be further optimized by nutrient supply [73] and by an appropriate tuning of both physical parameters and organic substrate concentrations [74]. These results are particularly interesting since glycerol is the main by-product of biofuel production; so, they pave the way for an eligible biorefinery approach, which couples the production of metabolites for the food and feed industries with the production of green energy in the same route.

\section{6. $\mathrm{CO}_{2}$}

$\mathrm{CO}_{2}$ is the main carbon source for autotrophic organisms, including microalgae, and can stimulate or inhibit growth, depending on its concentration and microalgal tolerance. Adequate $\mathrm{CO}_{2}$ levels can optimize photosynthesis by enhancing its concentration in proximity of the enzyme ribulose-1,5-bisphosphate carboxylase-oxygenase (RuBisCO), and, in turn, algal growth and productivities. High $\mathrm{CO}_{2}$ supply is often counterbalanced by a reduction in oxygen $\left(\mathrm{O}_{2}\right)$ concentration. Previous works have shown that low $\mathrm{O}_{2}$ levels affected enzymatic desaturation in cyanobacteria [75], increasing PUFAs within their biomass. A similar trend was observed in the freshwater species Scenedesmus obliquus and Chlorella pyrenoidosa, where PUFAs increased at increasing $\mathrm{CO}_{2}$ concentrations [76]. A slight increase of unsaturated acids occurred also in Nannochloropsis sp. (strain MASCC11) in cells exposed to high (5-15\%) $\mathrm{CO}_{2}$ percentages [77]. The marine oleaginous microalga Microchloropsis gaditana showed both higher productivities and an increase of LC-PUFAs when exposed to high $(3 \% v / v)$ carbon dioxide levels with respect to air-insufflated (e.g., only $0.03 \% v / v \mathrm{CO}_{2}$ ) cultures [78].

\section{Genetic Engineering for PUFAs Production}

In the last years, genetic and metabolic engineering have been used to improve different features of organisms, for example, increasing the production of high-addedvalue biomolecules.

High-throughput sequencing technologies and genetic transformation techniques greatly contributed to enhance lipid production, and, in particular, PUFAs' accumulation, not only in microalgae but also in plants, yeasts, and bacteria. A number of strategies can be employed to regulate genes involved in lipid metabolism and PUFAs' biosynthesis, generally perturbing gene expression by overexpressing or silencing endogenous genes; common strategies are the overexpression of enzymes of the FAs' or TAGs' biosynthesis pathway, the perturbation of the regulation of related biosynthetic pathways, the block of competing pathways, and, in some cases, the use of a multi-gene transgenic approach $[79,80]$. Furthermore, several researchers highlighted the possibility of heterologous protein expression in different organisms: This means expressing microalgae proteins in other microalgae or in other organisms or expressing proteins from other organisms in microalgae. These studies allowed, firstly, characterizing a large number of genes involved in different metabolic pathways and, secondly, identifying interesting targets for increasing PUFAs' production.

\subsection{Genetic Transformation and Gene Perturbation in Microalgae}

Several transformation methods were recently developed and optimized, allowing the introduction of genetic material into the cell nucleus and, hence, the genetic manipulation 
of numerous microalgal species: among the most relevant ones, there are the model microalgae C. reinhardtii, P. tricornutum, and Nannochloropsis spp., all promising lipidproducing species. Nuclear transformation in microalgae is possible through methods ranging from nanoparticles' bombardment [81] and agitation with glass beads [82], to the introduction of an episome via bacterial conjugation [83], Agrobacterium construction [84], and electroporation [85]. These techniques are mainly used to manipulate gene expression.

Different approaches ranging from random to targeted mutagenesis have been used in microalgae.

The random mutagenesis approach carried out throughout physical or chemical mutagens can be applied to species for which genetic transformations are not possible. This method causes alterations to the organism's DNA, followed by selection of mutants with the desired metabolic properties [86].

Although random mutagenesis produced a lot of interesting results [86], the recent development of nuclear transformation and the availability of genome sequences for an increasing number of model species contributed to enlarge the collection of tools for targeted mutagenesis allowing overexpression and knock-down or knock-out of specific target genes in microalgae.

Gene overexpression is carried out by means of constructs containing strong regulatory sequences, driving an increased expression of the gene of interest. On the other hand, RNA interference (RNAi) is used for targeted gene downregulation (knock-down), which occurs through a variety of mechanisms, including translation, inhibition, RNA degradation, and/or transcriptional repression $[87,88]$. More recently, genome editing tools such as sequence-specific DNA nuclease technologies are playing an increasingly important and revolutionary role, enabling targeted modification of genomic sequences (knock-out) with high efficiency, and also in traditionally genetically intractable species. Among DNA nuclease technologies, TALENs (transcription activator-like effector nucleases) and CRISPR/Cas9 (clustered regulatory interspaced short palindromic repeats) are being used in microalgae. TALENs are chimeric proteins that contain two functional domains, a DNA-recognition transcription activator-like effector (TALE), and a DNA nuclease domain, which work together to recognize a specific DNA sequence and introduce a double-stranded break with an overhang [87,89], while the CRISPR/Cas9 system consists of a CRISPR-associated endonuclease (Cas protein), which cuts DNA in a specific target region determined by a short guide RNA, introducing a double-stranded break [87]. A variation of this last technique is CRISPR interference (CRISPRi), which provides a complementary approach to RNAi with the difference that CRISPRi regulates gene expression primarily on the transcriptional level, while RNAi controls genes on the mRNA level [90].

An overview of the studies that have produced successful results through microalgae mutagenesis and genetic manipulation, along with several unsuccessful attempts, are presented on Table 2. Each study contributed to reconstruct the metabolic pathways of interest for PUFAs' production and allowed identifying more promising targets for subsequent biotechnological applications.

\subsection{Enhancement of the Fatty Acid Biosynthetic Pathway}

The main approach includes the direct modification of FAs' composition through the manipulation of the genes involved in FA biosynthesis (Figure 2), generally by increasing the expression of one or more enzymes. 
Table 2. Effect of different genetic modifications for enhancing PUFAs' accumulation in microalgae. Studies are grouped by genetic modification, such as overexpression, silencing/knock-out, and heterologous expression, and then by the pathway in which the gene of interest is involved. The table represents the results obtained through specific genetic modifications. Genes and pathways are reported in Uniprot (https:/ / www.uniprot.org/uniprot, accessed on 29 November 2021). Differences are shown as percentage increases, indicating the surplus over the wild-type control condition.

\begin{tabular}{|c|c|c|c|c|c|}
\hline \multicolumn{6}{|c|}{ Overexpression } \\
\hline Gene & Pathway & $\begin{array}{l}\text { Microalgal } \\
\text { Species }\end{array}$ & & Results & Reference \\
\hline AGPAT1 & TAG biosynthesis & P. tricornutum & $\begin{array}{r}+50 \% \mathrm{EPA},+5 \\
\mathrm{~T}\end{array}$ & $\begin{array}{l}\% \text { DHA content, }+80 \% \\
\text { G content }\end{array}$ & [91] \\
\hline GPAT & TAG biosynthesis & P. tricornutum & $+41 \%$ & PUFA content & [92] \\
\hline DGAT2 & TAG biosynthesis & P. tricornutum & \multirow{2}{*}{\multicolumn{2}{|c|}{$\begin{array}{c}+100 \% \text { total lipid, }+80 \% \text { TAG content, }+20 \% \\
\text { EPA content }\end{array}$}} & [93] \\
\hline DGAT2 & TAG biosynthesis & P. tricornutum & & & [94] \\
\hline DGAT2 & TAG biosynthesis & N. oceanica & \multicolumn{2}{|c|}{$+69 \%$ neutral lipid content } & [95] \\
\hline DGAT1A & TAG biosynthesis & N. oceanica & \multicolumn{2}{|c|}{$+39 \%$ TAG content } & [96] \\
\hline DGTT1-3 & TAG biosynthesis & C. reinhardtii & \multicolumn{2}{|c|}{ no changes in lipid content } & [97] \\
\hline DGTT4 & TAG biosynthesis & C. reinhardtii & \multicolumn{2}{|c|}{$+2800 \%$ TAG content } & [98] \\
\hline GPAT, DGAT2 & TAG biosynthesis & P. tricornutum & \multicolumn{2}{|c|}{$+170 \%$ total lipid content } & [99] \\
\hline GK & TAG biosynthesis & F. solaris & \multicolumn{2}{|c|}{$+12 \%$ total lipid content } & [100] \\
\hline GPDH & TAG biosynthesis & P. tricornutum & \multicolumn{2}{|c|}{$+60 \%$ TAG content } & [101] \\
\hline LPAAT1 & TAG biosynthesis & C. reinhardtii & \multicolumn{2}{|c|}{$+20 \%$ TAG content } & [102] \\
\hline thioesterase & FA biosynthesis & P. tricornutum & \multicolumn{2}{|c|}{$+72 \%$ total lipid, $+10 \%$ EPA content } & [103] \\
\hline $\mathrm{TE}$ & FA biosynthesis & P. tricornutum & \multirow{2}{*}{\multicolumn{2}{|c|}{$\begin{array}{c}+16 \% \text { EPA content } \\
+100 \% \text { EPA },+340 \% \text { DHA content },+32 \% \text { total } \\
\text { FA content }\end{array}$}} & [103] \\
\hline ACP, KAS, FAT & FA biosynthesis & H. pluvialis & & & [104] \\
\hline ME & FA biosynthesis & P. tricornutum & \multicolumn{2}{|c|}{$+150 \%$ total lipid content, $-10 \%$ PUFA content } & [105] \\
\hline MCAT & FA biosynthesis & N. oceanica & \multicolumn{2}{|c|}{$+31 \%$ neutral lipid, $+8 \%$ EPA content } & [106] \\
\hline MCAT & FA biosynthesis & Schizochytrium sp. & \multicolumn{2}{|c|}{$+172.5 \% \mathrm{EPA},+81.5 \% \mathrm{DHA},+69.2 \%$ DPA content } & [107] \\
\hline FA elongase & FA biosynthesis & T. pseudonana & \multicolumn{2}{|c|}{$+40 \% \mathrm{EPA},+350 \%$ DHA content } & [108] \\
\hline$\Delta 5$ desaturase & FA biosynthesis & P. tricornutum & \multicolumn{2}{|c|}{$+65 \%$ TAG content, $+58 \%$ EPA content } & [109] \\
\hline$\Delta 12$ desaturase & FA biosynthesis & N. oceanica & \multicolumn{2}{|c|}{$+75 \%$ AA content } & [110] \\
\hline bHLH2 & transcription factor & N. salina & \multicolumn{2}{|c|}{$+33 \%$ total lipid content } & [111] \\
\hline DOF & transcription factor & C. reinhardtii & \multicolumn{2}{|c|}{$+100 \%$ total lipid content } & [112] \\
\hline DOF & transcription factor & C. reinhardtii & \multicolumn{2}{|c|}{$+170 \%$ total lipid content } & [113] \\
\hline PSR1 & transcription factor & C. reinhardtii & \multicolumn{2}{|c|}{ no quantified reduction of neutral lipid content } & [114] \\
\hline PSR1 & transcription factor & C. reinhardtii & \multicolumn{2}{|c|}{$+10 \%$ TAG content } & [115] \\
\hline bZIP & transcription factor & N. salina & \multicolumn{2}{|c|}{$+50 \%$ total lipid content } & [116] \\
\hline PNPLA3 & lipid turnover & P. tricornutum & \multicolumn{2}{|c|}{$+70 \%$ neutral lipid, $+26 \%$ PUFA content } & [117] \\
\hline LDP1 & $\begin{array}{l}\text { lipid droplet } \\
\text { metabolism }\end{array}$ & P. tricornutum & \multicolumn{2}{|c|}{$+30 \%$ total lipid, $+40 \%$ neutral lipid content } & [118] \\
\hline ACCase & $\begin{array}{l}\text { pyruvate } \\
\text { metabolism }\end{array}$ & C. cryptica & no chang & s in lipid content & [119] \\
\hline G6PD & $\begin{array}{l}\text { carbohydrates } \\
\text { metabolism }\end{array}$ & P. tricornutum & $+170 \% \mathrm{t}$ & tal lipid content & [120] \\
\hline NOA & $\begin{array}{l}\text { nitric oxide } \\
\text { metabolism }\end{array}$ & P. tricornutum & $+80 \%$ neutral li & $\mathrm{id},+400 \%$ TAG content & [121] \\
\hline & & & & & \\
\hline Gene & Pathway & Method & Microalgal Species & Results & Reference \\
\hline AGPase & $\begin{array}{l}\text { Carbohydrates' } \\
\text { metabolism }\end{array}$ & $\begin{array}{c}\text { random } \\
\text { mutagenesis }\end{array}$ & C. reinhardtii & $\begin{array}{c}+250 \% \text { total lipids, }+900 \% \\
\text { TAG content }\end{array}$ & {$[122]$} \\
\hline isoamylase & $\begin{array}{l}\text { Carbohydrates' } \\
\text { metabolism }\end{array}$ & $\begin{array}{l}\text { random } \\
\text { mutagenesis }\end{array}$ & C. reinhardtii & $+450 \%$ total lipid content & [123] \\
\hline UGPase & $\begin{array}{l}\text { Carbohydrates' } \\
\text { metabolism }\end{array}$ & TALEN & P. tricornutum & $+4400 \%$ TAG content & [124] \\
\hline UGPase & $\begin{array}{l}\text { Carbohydrates' } \\
\text { metabolism }\end{array}$ & RNAi & P. tricornutum & $+4 \%$ total lipid content & [125] \\
\hline CS & $\begin{array}{l}\text { Carbohydrates' } \\
\text { metabolism }\end{array}$ & RNAi & T. pseudonana & $+200 \%$ TAG content & [126] \\
\hline
\end{tabular}


Table 2. Cont.

\begin{tabular}{|c|c|c|c|c|c|}
\hline \multicolumn{6}{|c|}{ Overexpression } \\
\hline Gene & Pathway & $\begin{array}{l}\text { Microalgal } \\
\text { Species }\end{array}$ & & Results & Reference \\
\hline SLM1 & $\begin{array}{l}\text { Carbohydrates' } \\
\text { metabolism }\end{array}$ & $\begin{array}{l}\text { random } \\
\text { mutagenesis }\end{array}$ & S. obliquus & $+51 \%$ TAG content & [127] \\
\hline PEPC1 & $\begin{array}{l}\text { pyruvate } \\
\text { metabolism }\end{array}$ & CRISPRi & C. reinhardtii & $+74 \%$ total lipid content & [128] \\
\hline PEPC1 & $\begin{array}{l}\text { pyruvate } \\
\text { metabolism }\end{array}$ & RNAi & C. reinhardtii & $+20 \%$ TAG content & [129] \\
\hline PEPC1, PEPC2 & $\begin{array}{l}\text { pyruvate } \\
\text { metabolism }\end{array}$ & RNAi & C. reinhardtii & $+48 \%$ FA content & [130] \\
\hline PEPCK & $\begin{array}{l}\text { pyruvate } \\
\text { metabolism }\end{array}$ & RNAi & P. tricornutum & $+40 \%$ total lipid content & [131] \\
\hline CIS & $\begin{array}{l}\text { pyruvate } \\
\text { metabolism }\end{array}$ & RNAi & C. reinhardtii & $+170 \%$ TAG content & [129] \\
\hline PDK & $\begin{array}{l}\text { pyruvate } \\
\text { metabolism }\end{array}$ & RNAi & P. tricornutum & $\begin{array}{l}+82 \% \text { neutral lipid, no } \\
\text { changes in FA content }\end{array}$ & [132] \\
\hline lipase & lipid turnover & RNAi & T. pseudonana & $\begin{array}{c}+300 \% \mathrm{EPA},+220 \% \mathrm{DHA} \\
\text { content }\end{array}$ & {$[133]$} \\
\hline omTGL & lipid turnover & RNAi & P. tricornutum & $+70 \%$ EPA content & [134] \\
\hline TGL1 & lipid turnover & RNAi & P. tricornutum & $\begin{array}{c}+200 \% \mathrm{TAG},+10 \% \mathrm{EPA} \\
\text { content }\end{array}$ & [135] \\
\hline LIP1 & lipid turnover & RNAi & C. reinhardtii & +150\% TAG content & [136] \\
\hline $\mathrm{ACX} 2$ & B oxidation & $\begin{array}{l}\text { insertional } \\
\text { mutagenesis }\end{array}$ & C. reinhardtii & $\begin{array}{l}+400 \% \text { neutral lipid, }+70 \% \\
\text { TAG content }\end{array}$ & [137] \\
\hline MLDP & $\begin{array}{l}\text { lipid droplet } \\
\text { metabolism }\end{array}$ & RNAi & C. reinhardtii & no changes in TAG content & [138] \\
\hline LDP1 & $\begin{array}{l}\text { lipid droplet } \\
\text { metabolism }\end{array}$ & RNAi & P. tricornutum & $-20 \%$ total lipid content & [130] \\
\hline PDAT & TAG biosynthesis & RNAi & C. reinhardtii & $\begin{array}{c}\text { general reduction of all TAG } \\
\text { classes content }\end{array}$ & [139] \\
\hline SAD & FA biosynthesis & RNAi & C. reinhardtii & $+40 \%$ stearic acid content & [140] \\
\hline$\omega-3$-DES & FA biosynthesis & $\begin{array}{l}\text { homologous } \\
\text { recombination }\end{array}$ & C. vulgaris & $\begin{array}{c}\text { no changes in PUFA and FA } \\
\text { content }\end{array}$ & [141] \\
\hline TES1 & FA biosynthesis & TALEN & P. tricornutum & $+70 \%$ TAG content & [142] \\
\hline $\mathrm{PDH}$ & FA biosynthesis & RNAi & C. reinhardtii & $-50 \%$ FA content & [143] \\
\hline DGTT & FA biosynthesis & RNAi & C. reinhardtii & $-35 \%$ TAG content & [144] \\
\hline NR & $\mathrm{N}$ assimilation & TALEN & P. tricornutum & $+20 \%$ TAG content & [145] \\
\hline NR & $\mathrm{N}$ assimilation & RNAi & P. tricornutum & $+43 \%$ total lipid content & [146] \\
\hline ZnCys & transcription factor & RNAi & N. gaditana & $+35 \%$ total lipid content & [147] \\
\hline- & - & $\begin{array}{l}\text { random } \\
\text { mutagenesis }\end{array}$ & P. lutheri & $\begin{array}{c}+33 \% \mathrm{EPA},+33 \% \mathrm{DHA} \\
\text { content }\end{array}$ & [148] \\
\hline- & - & $\begin{array}{l}\text { insertional } \\
\text { mutagenesis }\end{array}$ & N. oceanica & $\begin{array}{c}+180 \% \text { PUFA, }+40 \% \text { EPA } \\
\text { content }\end{array}$ & [149] \\
\hline \multicolumn{6}{|c|}{ Heterologous expression } \\
\hline Gene & Pathway & Source species & $\begin{array}{l}\text { Receiver } \\
\text { species }\end{array}$ & Results & Reference \\
\hline \multicolumn{6}{|c|}{ Genes from microalgae in other microalgae } \\
\hline GPAT & TAG biosynthesis & L. incisa & C. reinhardtii & $+50 \%$ FA content & [150] \\
\hline ELO5 & FA biosynthesis & O. tauri & P. tricornutum & $+700 \%$ DHA content & [151] \\
\hline ELO5, DES6 & FA biosynthesis & O. tauri & P. tricornutum & $+800 \%$ DHA content & [151] \\
\hline$\triangle 5 \mathrm{DES}$ & FA biosynthesis & T. aureum & A. limacinum & $\begin{array}{c}+360 \% \text { EPA, }+1220 \% \text { AA } \\
\text { content }\end{array}$ & [152] \\
\hline ME & FA biosynthesis & P. tricornutum & C. pyrenoidosa & $+220 \%$ neutral lipid content & [105] \\
\hline (Bn)AccD, (Cr)ME & $\begin{array}{l}\text { pyruvate } \\
\text { metabolism }\end{array}$ & $\begin{array}{l}\text { B. napus, C. } \\
\text { reinhardtii }\end{array}$ & D. salina & $+12 \%$ total lipid content & {$[153]$} \\
\hline
\end{tabular}


Table 2. Cont.

\begin{tabular}{|c|c|c|c|c|c|}
\hline \multicolumn{6}{|c|}{ Overexpression } \\
\hline Gene & Pathway & $\begin{array}{l}\text { Microalgal } \\
\text { Species }\end{array}$ & & Results & Reference \\
\hline ACCase & $\begin{array}{l}\text { pyruvate } \\
\text { metabolism }\end{array}$ & C. cryptica & N. saprophila & no changes in lipid content & {$[119]$} \\
\hline thioesterase & FA biosynthesis & D. tertiolecta & C. reinhardtii & $+50 \%$ FA content & {$[154]$} \\
\hline DGAT2 & TAG biosynthesis & C. reinhardtii & S. obliquus & $+85 \%$ total lipid content & [155] \\
\hline \multicolumn{6}{|c|}{ Genes from other organisms in microalgae } \\
\hline DGAT2 & TAG biosynthesis & B. napus (plant) & P. tricornutum & $+12 \%$ ALA content & [156] \\
\hline DGA1 & TAG biosynthesis & S. cerevisiae (yeast) & P. tricornutum & $+130 \%$ TAG content & {$[157]$} \\
\hline OLEO3 & TAG biosynthesis & A. thaliana (plant) & P. tricornutum & +40\% TAGcontent & {$[157]$} \\
\hline $\begin{array}{l}(\mathrm{Sc}) \mathrm{DGA} 1 \\
(\mathrm{At}) \mathrm{OLEO} 3\end{array}$ & TAG biosynthesis & $\begin{array}{l}\text { S. cerevisiae (yeast), } \\
\text { A. thaliana (plant) }\end{array}$ & P. tricornutum & $+260 \%$ TAG content & [157] \\
\hline $\begin{array}{l}\text { (Sc)G3PDH-GPAT- } \\
\text { LPAAT, } \\
\text { (Y1)DGATs }\end{array}$ & TAG biosynthesis & $\begin{array}{c}\text { S. cerevisiae, } Y \text {. } \\
\text { lipolytica (yeasts) }\end{array}$ & C. minutissima & $+120 \%$ total lipid content & {$[158]$} \\
\hline$\triangle 3 \mathrm{DES}$ & FA biosynthesis & S. dicilina (yeast) & $\begin{array}{l}\text { Schizochytrium } \\
\text { sp. }\end{array}$ & $+3 \%$ DHA content & {$[159]$} \\
\hline $\mathrm{ACP}$ reductase & FA biosynthesis & $\begin{array}{l}\text { Synechocystis sp. } \\
\text { (cyanobacteria) }\end{array}$ & C. merolae & $+133 \%$ TAG content & {$[160]$} \\
\hline $\begin{array}{l}(\mathrm{Cc}) \mathrm{C} 14-\mathrm{TE} \\
(\mathrm{Uc}) \mathrm{C} 12-\mathrm{TE}\end{array}$ & FA biosynthesis & $\begin{array}{c}\text { C. camphora, U. } \\
\text { californica (plants) }\end{array}$ & P. tricornutum & $+80 \%$ TAG content & {$[161]$} \\
\hline $\begin{array}{l}(\mathrm{Cc}) \mathrm{C} 14-\mathrm{TE}, \\
(\mathrm{Uc}) \mathrm{C} 12-\mathrm{TE}, \\
(\mathrm{Ch}) \mathrm{KAS}\end{array}$ & FA biosynthesis & $\begin{array}{c}\text { C. camphora, } U \text {. } \\
\text { californica, } C \text {. } \\
\text { hookeriana (plants) }\end{array}$ & D. tertiolecta & $+4 \%$ FA content & {$[162]$} \\
\hline $\begin{array}{c}\text { C14-TE, C10-TE, } \\
\text { ACP }\end{array}$ & FA biosynthesis & C. lanceolata (plant) & C. reinhardtii & $\begin{array}{l}\text { general increase in different } \\
\text { FAs classes content }\end{array}$ & {$[163]$} \\
\hline$(\mathrm{Bn}) \mathrm{AccD},(\mathrm{Cr}) \mathrm{ME}$ & $\begin{array}{l}\text { pyruvate } \\
\text { metabolism }\end{array}$ & $\begin{array}{l}\text { B. napus (plant), C. } \\
\text { reinhardtii }\end{array}$ & D. salina & $+12 \%$ total lipid content & {$[153]$} \\
\hline $\mathrm{ACC} 1$ & $\begin{array}{l}\text { pyruvate } \\
\text { metabolism }\end{array}$ & S. cerevisiae (yeast) & S. quadricauda & $+60 \%$ FA content & {$[164]$} \\
\hline $\begin{array}{l}\text { ACC1, GDP1, } \\
\text { GUT1 }\end{array}$ & $\begin{array}{l}\text { pyruvate } \\
\text { metabolism }\end{array}$ & S. cerevisiae (yeast) & S. quadricauda & $+50 \%$ total lipid content & {$[164]$} \\
\hline ACS & $\begin{array}{l}\text { pyruvate } \\
\text { metabolism }\end{array}$ & E. coli (bacteria) & $\begin{array}{l}\text { Schizochytrium } \\
\text { sp. }\end{array}$ & no changes in lipid content & {$[165]$} \\
\hline $\begin{array}{l}\text { (An)PhyA, } \\
\text { (Ot)Elo5 }\end{array}$ & $\begin{array}{l}\text { phytate } \\
\text { metabolism }\end{array}$ & $\begin{array}{c}\text { A. niger (yeast), } O . \\
\text { tauri }\end{array}$ & P. tricornutum & $\begin{array}{c}+10 \% \text { DHA, }-25 \% \text { EPA } \\
\text { content }\end{array}$ & {$[166]$} \\
\hline $\begin{array}{l}\text { (Ec)AppA, } \\
(\mathrm{Ot}) \text { Elo5 }\end{array}$ & $\begin{array}{l}\text { phytate } \\
\text { metabolism }\end{array}$ & $\begin{array}{c}\text { E. coli (bacteria), } O . \\
\text { tauri }\end{array}$ & P. tricornutum & $\begin{array}{l}+12 \% \text { DHA, }-18 \% \text { EPA } \\
\text { content }\end{array}$ & {$[166]$} \\
\hline DOF4 & transcription factor & G. $\max ($ plant $)$ & C. ellipsoidea & $+53 \%$ total lipid content & {$[167]$} \\
\hline WRI1 & transcription factor & A. thaliana (plant) & N. salina & $+64 \%$ tota lipid content & [168] \\
\hline \multicolumn{6}{|c|}{ Genes from microalgae in other organisms } \\
\hline antisense PEPC & $\begin{array}{l}\text { pyruvate } \\
\text { metabolism }\end{array}$ & Anabaena sp. & E. coli (bacteria) & $+47 \%$ lipid content & {$[169]$} \\
\hline ACCase & $\begin{array}{l}\text { pyruvate } \\
\text { metabolism }\end{array}$ & P. tricornutum & E. coli (bacteria) & $+100 \%$ neutral lipid content & {$[170]$} \\
\hline$\Delta 9-\mathrm{ELO}$ & FA biosynthesis & I. galbana & $\begin{array}{l}\text { A. thaliana } \\
\text { (plant) }\end{array}$ & $+18 \%$ PUFA content & {$[171]$} \\
\hline $\begin{array}{l}\Delta 9 \text {-ELO (codon } \\
\text { optimized) }\end{array}$ & FA biosynthesis & I. galbana & $\begin{array}{l}\text { A. thaliana } \\
\text { (plant) }\end{array}$ & $+64 \%$ PUFA content & {$[172]$} \\
\hline$\Delta 6-\mathrm{DES}$ & FA biosynthesis & M. pusilla & $\begin{array}{l}\text { A. thaliana } \\
\text { (plant) }\end{array}$ & $+26 \%$ EPA content & {$[173]$} \\
\hline $\begin{array}{l}(\mathrm{Ig}) \Delta 9 \mathrm{E},(\mathrm{Eg}) \Delta 8 \mathrm{D} \\
(\mathrm{Ma}) \Delta 5 \mathrm{D}\end{array}$ & FA biosynthesis & $\begin{array}{l}\text { I. galbana, E. } \\
\text { gracilis, M. alpina }\end{array}$ & $\begin{array}{l}\text { A. thaliana } \\
\text { (plant) }\end{array}$ & $\begin{array}{c}+23 \% \text { PUFA, }+3 \% \text { EPA, } \\
+7 \% \text { AA content }\end{array}$ & {$[171]$} \\
\hline $\begin{array}{c}(\mathrm{Pt}) \Delta 5 \mathrm{D},(\mathrm{Pt}) \Delta 6 \mathrm{D} \\
(\mathrm{Pp}) \Delta 6 \mathrm{E}\end{array}$ & FA biosynthesis & $\begin{array}{c}\text { P. tricornutum, } \\
\text { Physcomitrella } \\
\text { patens }\end{array}$ & $\begin{array}{l}\text { N. tabacum } \\
\text { (plant) }\end{array}$ & $+30 \%$ PUFA content & {$[174]$} \\
\hline
\end{tabular}


Table 2. Cont.

\begin{tabular}{|c|c|c|c|c|c|}
\hline \multicolumn{6}{|c|}{ Overexpression } \\
\hline Gene & Pathway & $\begin{array}{l}\text { Microalgal } \\
\text { Species }\end{array}$ & & Results & Reference \\
\hline $\begin{array}{l}(\mathrm{Pt}) \Delta 5 \mathrm{D},(\mathrm{Pt}) \Delta 6 \mathrm{D} \\
(\mathrm{Pp}) \Delta 6 \mathrm{E}\end{array}$ & FA biosynthesis & $\begin{array}{l}\text { P. tricornutum, } P \text {. } \\
\text { patens }\end{array}$ & $\begin{array}{l}\text { L. usitatissimum } \\
\text { (plant) }\end{array}$ & $+30 \%$ PUFA content & [174] \\
\hline $\begin{array}{l}\text { (Sc)PUFA- } \\
\text { synthase, } \\
\text { (No)PPTase }\end{array}$ & FA biosynthesis & $\begin{array}{l}\text { Schizochytrium sp., } \\
\text { Nostoc sp. }\end{array}$ & $\begin{array}{l}\text { A. thaliana } \\
\text { (plant) } \\
\text { B. napus (plant) }\end{array}$ & $+4 \%$ DHA, $+1 \%$ EPA content & [175] \\
\hline ELO5 & FA biosynthesis & P. tricornutum & P. pastoris (yeast) & $\begin{array}{l}\text { no quantified increase in } \\
\text { DPA and DTA content }\end{array}$ & [176] \\
\hline (Pt)ELO5, (Is)DES4 & FA biosynthesis & $\begin{array}{l}\text { P. tricornutum, } I \text {. } \\
\text { sphaerica }\end{array}$ & P. pastoris (yeast) & $\begin{array}{c}+3 \% \text { DPA },+2.35 \% \text { DHA } \\
\text { content }\end{array}$ & [176] \\
\hline DES2 & FA biosynthesis & C. vulgaris & $\begin{array}{l}\text { S. cerevisiae } \\
\text { (yeast) }\end{array}$ & $\begin{array}{l}\text { no quantified reduction of } \\
\text { LA content }\end{array}$ & [177] \\
\hline DGTT2 & FA biosynthesis & C. reinhardtii & $\begin{array}{l}\text { S. cerevisiae } \\
\text { (yeast) }\end{array}$ & $+800 \%$ TAG content & [178] \\
\hline $\begin{array}{l}(\mathrm{Pt}) \Delta 5 \mathrm{D},(\mathrm{Pt}) \Delta 6 \mathrm{D} \\
(\mathrm{Pp}) \Delta 6 \mathrm{E}\end{array}$ & FA biosynthesis & $\begin{array}{l}\text { P. tricornutum, } P \text {. } \\
\text { patens }\end{array}$ & $\begin{array}{l}\text { S. cerevisiae } \\
\text { (yeast) }\end{array}$ & $\begin{array}{c}+0.23 \% \mathrm{EPA},+0.17 \% \mathrm{AA} \\
\text { content }\end{array}$ & [179] \\
\hline DES6 & FA biosynthesis & M. pusilla & M. alpina (yeast) & +2500\% EPA content & [180] \\
\hline$\triangle 6 \mathrm{ELO}$ & FA biosynthesis & Isochrysis sp. & E. coli (bacteria) & $+6 \%$ SDA,$+3 \%$ GLA content & [181] \\
\hline $\begin{array}{l}\text { (Iso) } \Delta 6 \text { ELO, } \\
(\mathrm{Pav}) \Delta 5 \mathrm{DES}\end{array}$ & FA biosynthesis & $\begin{array}{l}\text { Isochrysis sp., } \\
\text { Pavlova sp. }\end{array}$ & E. coli (bacteria) & $\begin{array}{c}\text { no quantified increase of AA } \\
\text { and EPA content }\end{array}$ & [182] \\
\hline
\end{tabular}

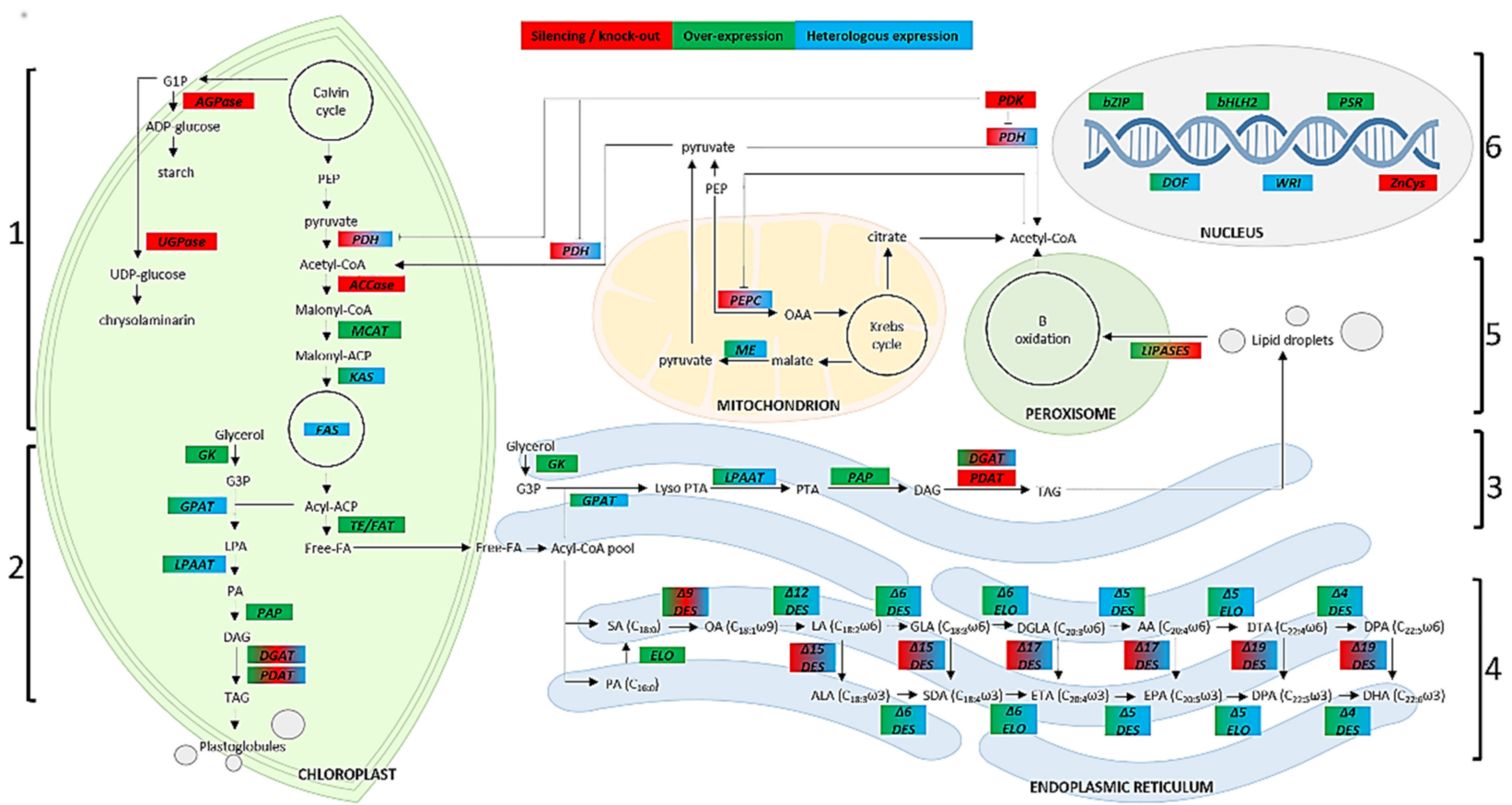

Figure 2. Schematic representation of microalgal lipid pathways. The enzymes are shown in squares with different colors, depending on the genetic manipulation that occurred: red for silencing or knock-out, green for overexpression, and blue for heterologous expression. Cellular organelles involved are plastid, endoplasmic reticulum, peroxisome, mitochondria cytosol, and nucleus. The numbers (from 1 to 6) near the square brackets indicate different figure sections. AA: Arachidonic Acid; ACCase: Acetyl-CoA Carboxylase; ACP: Acyl Carrier Protein; ADP-glucose: Adenosine-Diphosphate Glucose; AGPase: ADP-Glucose Pyrophosphorylase; bHLH2: Basic Helix-Loop-Helix transcription factor 2; bZIP: Basic Leucine Zipper transcription factor; CoA: Coenzyme A; DAG: Diacylglycerol; DES: Desaturase (the number near the Greek letter $\Delta$ indicates that the double bond is created at a fixed position from the carboxyl end of a fatty acid chain); DGAT: Diacylglycerol Acyltransferase; DGLA: Diacylglycerol Lipase Alpha; DHA: Docosahexaenoic Acid; DOF: DNA binding with One Finger type transcription factors; DPA: Docosapentaenoic Acid; DTA: Docosatetraenoic Acid; ELO: Elongase; EPA: Eicosapentaenoic 
Acid; ETA: Eicosatetraenoic Acid; FAS: Fatty Acid Synthase; G1P: Glycerol-1-Phosphate; G3P: Glycerol-3-Phosphate; GK: Glycerol Kinase; GLA: $\gamma$-Linolenic Acid; GPAT: Glycerol-3-Phosphate Acyltransferase; KAS: Beta-Ketoacyl-Acylcarrier-protein Synthase; LA: Linoleic Acid; LPA: Lysophosphatidic Acid; LPAAT: Lysophosphatidic Acid Acyltransferase; MCAT: Malonyl CoA-Acyl carrier protein Transacylase; ME: Malic Enzyme; OA: Oleic Acid; OAA: Oxalacetic Acid; PA: Palmitic Acid; PAP: Phosphatidic Acid Phosphatase; PEP: Phosphoenolpyruvate; PEPC: Phosphoenolpyruvate Carboxylase; PDAT: Phospholipid Diacylglycerol Acyltransferase; PDH: Pyruvate Dehydrogenase; PDK: Pyruvate Dehydrogenase Kinase; PSR: Phosphorus Stress Response transcription factor; PTA: Phosphatidic acid; SA: Stearic acid; SDA: Stearidonic Acid; TAG: Triacylglycerol; TE/FAT: Thioesterase/Acyl-ACP Thioesterase; UDP-glucose: Uracil-Diphosphate Glucose; UGPase: UDP-Glucose Pyrophosphorylase; WRI: WRINKLED1 transcription factor; ZnCys: Zinc/Cysteine transcription factor.

The malonyl-CoenzymeA (malonyl-CoA) generated by ACCase enters into de novo FA synthesis: Malonyl-CoA is first converted to malonyl-Acyl Carrier Protein (ACP) by Malonyl CoA-ACP transacylase (MCAT) [183] (Figure 2). Overexpression of the endogenous gene encoding MCAT in N. oceanica resulted in a 31\% increase in neutral lipids along with changes in FAs' composition with EPA increased by 8\% [106]. A similar approach in the heterotrophic protist Schizochytrium sp. led to a $172.5 \%$ increase in EPA, $81.5 \%$ increase in DHA, and $69.2 \%$ increase in docosapentaenoic acid (DPA- $\mathrm{C}_{22: 5} \mathrm{\omega} 3$ ) content [107]. KAS and acyl-ACP thioesterase (FAT) catalyzed the initial condensing reaction in FA biosynthesis [104] (Figure 2, sections 1 and 2). The overexpression of these three genes (a specific MCAT called MCTK, KAS, and FAT) in Haematococcus pluvialis led to a 2-fold increase in EPA content and more than 4-fold increase for DHA content, in addition to an overall increase of $32 \%$ total FAs' content [104]. KAS genes were combined with a thioesterase (TE) gene (FAT-A or FAT-B) to obtain a mutant that produced an increased amount of $\mathrm{C}_{8-16}$ FAs in the microalgae Chlorella or Prototheca spp. [184]. Heterologous co-expression of a polyketide synthase-like PUFA synthase system (FAS) (Figure 2, sections 1 and 2) from Schizochytrium sp. and a phosphopantetheinyl transferases (PPTase) from Nostoc in canola (Brassica napus) seeds showed an increase in de novo synthesis of DHA and EPA from malonyl-CoA without substantially altering plastidial FAs' production [175]. Overexpression of a P. tricornutum TE did not alter the FAs' composition of $P$. tricornutum, but enhanced total FAs' content by $72 \%$ and EPA content by $10 \%$ [103]. Lastly, Ozaki [185] provided an efficient lipid production method through heterologous expression of Nannochloropsis sp. Acyl-ACP TE in Escherichia coli.

The overexpression of enzymes catalysing the last steps of a biosynthetic pathway is often preferred and can easily lead to increased biosynthesis of the final product of the pathway. This is due to the fact that pathways are often controlled by a single enzyme typically catalysing the final reaction and thus the metabolic pathway flux (and the concentration of the final product of the pathway) [186]. It is, thus, physiologically more common to change a metabolic flux and the production of the final metabolite in the pathway than varying the intermediary concentrations [187]. Nevertheless, in this case, the most promising results were obtained from the overexpression of upstream enzymes such as MCAT [107]. Furthermore, an interesting strategy consists of the overexpression of several enzymes involved in the same biosynthesis pathway, such as MCAT, KAS, and FAT, which together allowed doubling up to a quadrupling of the amount of EPA and DHA final products [104].

\subsection{Altering Elongation and Desaturation}

De novo produced saturated FAs, PA, and stearic acid (SA-C $\left.\mathrm{C}_{18: 0}\right)$ can undergo desaturation by plastid or endoplasmic reticulum (ER) desaturases (DES) and elongation by different elongases (ELO), producing FAs with different degrees of unsaturation and with different chain length (Figure 2, section 3). Therefore, another more precise strategy to alter FA composition is to interfere with desaturation and elongation processes by selectively acting on elongases and/or desaturases.

Stearoyl-ACP desaturase (SAD) is a $\triangle 9$-DES that catalyzes the conversion of SA into oleic acid $\left(\mathrm{OA}-\mathrm{C}_{18: 1} \omega 9\right)$. The reduction of activity of this enzyme could, thus, potentially 
lead to the accumulation of SA. It has been reported that gene silencing of SAD enhances SA content in C. reinhardtii [140]. After that, desaturase $\triangle 12-\mathrm{DES}$ converts OA into LA. Overexpression of $\triangle 12$-DES in $N$. oceanica significantly altered composition of total lipids and of individual lipid classes, with a drastic increase in an 18:2 proportion in phosphatidylcholine and in TAG under nitrogen starvation [110]. Some LA was converted further toward LCPUFA, resulting in a 75\% increase in AA [110]. The enzyme $\omega-3$ desaturase ( $\omega$-3-DES or $\triangle 15$-DES) catalyzed the conversion of LA to ALA. Genetic modification in C. vulgaris by introducing the disrupted gene $\triangle 15$-DES through homologous recombination led to higher production of PA with a reduction in OA, with no remarkable changes observed in ALA composition [141]. The exogenous $\triangle 15$-DES gene from yeast in Schizochytrium led to greater cell size and lower polar lipid content than the wild-type (WT) strains [159]. In addition, the introduction of $\triangle 15$-DES improved the $\omega-3 / \omega-6$ ratio from 2.1 to 2.6 and converted $3 \%$ DPA to DHA [159]. Desaturase $\triangle 5$-DES is the key enzyme responsible for AA production, but it can also convert eicosatetraenoic acid (ETA- $\left.\mathrm{C}_{20: 4} \omega 3\right)$ into EPA. When the $\triangle 5$-DES gene was overexpressed in P. tricornutum, FA composition was altered, with a $65 \%$ increase in TAG content and 58\% in EPA content. Engineered cells showed a similar growth rate to the wild-type, thus keeping high biomass productivity [109]. Another example of increasing PUFA biosynthesis is the heterologous expression of a $\triangle 5$-DES from the thraustochytrid Thraustochytrium aureum in another thraustochytrids, Aurantiochytrium limacinum: The amount of EPA in the transgenic thraustochytrids increased 4.6-fold, while AA content showed a 13.2-fold increase [152]. Moreover, a recent study demonstrated that overexpression of endogenous FA elongase genes in T. pseudonana can increase levels of EPA and DHA up to 1.4- and 4.5-fold, respectively [108]. Subsequently, $\Delta 5$-elongase $\left(\Delta 5\right.$-ELO) catalyzed AA conversion into docosatetraenoic acid (DTA, $\left.\mathrm{C}_{22: 4} \omega 6\right)$. The same enzyme can also convert EPA into DPA. P. tricornutum does not naturally accumulate significant levels of DHA [188], but it has been reported that the heterologous expression of the $\Delta 5$-ELO from Ostreococcus tauri in P. tricornutum resulted in an 8-fold increase in DHA, and the co-expression of an acyl-CoA-dependent desaturase (Ot $\Delta 6-\mathrm{DES})$ and an elongase (Ot $\triangle 5$-ELO) from O. tauri into P. tricornutum displayed a further increase in DHA levels [151]. Substitution of fish oil with vegetable oil and fish meal with plant seed meals in aquaculture feeds reduced the levels of valuable $\omega-3$ LC-PUFAs such as EPA and DHA and lowered the nutritional value due to the presence of phytate. In order to solve this problem, Pudney and co-workers engineered P. tricornutum, accumulating high levels of EPA and DHA together with exogenous proteins: the fungal Aspergillus niger PhyA or the bacterial E. coli AppA phytases, in combination with a O. tauri $\triangle 5-E L O$, increasing, respectively, DHA content (10-12\%) [166].

The modification of FAs' desaturation and elongation pathways alters their proportions inside cells and, depending on the target genes, allows obtaining greater quantities of specific FAs, which can have different subsequent applications. These molecules can be produced by the microalgae or by other organisms, depending on the final purpose. In some cases, for the study of a particular enzyme, the purification of the final product or the biotechnological application of interest, other organisms, such as plants, bacteria, or yeasts, may be preferable to the use of microalgae.

In this context, key enzymes present in microalgae can be heterologously expressed in crops, increasing the levels of PUFAs such as EPA and DHA, which are particularly interesting from a nutritional point of view, improving the nutritional values of final products deriving from those plants, which, thus, find application as feed, food supplements, or nutraceuticals [174,189].

For example, the heterologous expression of a $\triangle 9$-ELO gene from the microalga I. galbana in Arabidopsis thaliana resulted in an A. thaliana mutant able to biosynthesise the LC-PUFAs $C_{20: 2} \omega 6$ and $C_{20: 3} \omega 3$ [163,164]. The co-expression of a $\triangle 9$-ELO gene from I. galbana and a $\triangle 8$-DES from Euglena gracilis into A. thaliana genome led to a mutant able to produce two other LC-FA, the $\mathrm{C}_{20: 3} \omega 6$ and the $\mathrm{C}_{20: 4} \omega 3$ FAs [171]. 
Another research using edible plants as receiver species showed that seed-specific expression in transgenic tobacco (Nicotiana tabacum) and linseed (Linum usitatissimum) of cDNAs encoding FAs' desaturases and elongases from the diatom P. tricornutum and the moss Physcomitrella patens, absent from all agronomically important plants, resulted in the very high FAs' accumulation (30\%), in particular, $\omega$-6-desaturated $C_{18}$ FAs and $C_{20}$ PUFAs including AA and EPA [174]. Furthermore, Petrie and co-workers engineered an artificial pathway that produced $26 \%$ EPA in plant leaf triacylglycerol using a newly identified $\triangle 6$-DES from the marine microalga Micromonas pusilla, which converted LA into $\gamma$-linolenic acid (GLA-C ${ }_{18: 3} \omega 6$ ). The $\triangle 6$-DES from $M$. pusilla was also demonstrated to function as an acyl-CoA desaturase with a preference for $\omega-3$ substrates [173].

The heterologous expression of microalgal genes in other organisms can be an advantage when these other organisms can be cultured more efficiently than microalgae. Bacteria and yeasts have been the pioneering hosts for recombinant protein production because of their fast growth and easy culturability. The genetic structure and physiology of bacteria and yeasts are well known, making metabolic pathway modification through genetic engineering easier than in other organisms. Furthermore, the heterologous expression in bacteria or yeasts can allow a more in-depth study of specific enzymes through biochemical and functional analyses, which are often more complicated in microalgae.

EPA production from E. coli is being considered as an alternative and economic source for industrial and pharmaceutical sectors. A novel $\Delta 6-\mathrm{ELO}$, which converts GLA into dihomo- $\gamma$-linoleic acid (DHGLA-C $C_{20: 3} \omega 6$ ), and a novel $\Delta 5$-DES were isolated from Isocrysis sp. and Pavlova sp., respectively, and expressed in bacteria, obtaining a strong increase in AA and EPA content $[181,182]$.

As regards studies carried out on yeasts, to enhance EPA production in Mortierella alpina by favouring the $\omega-3$ pathway, a plasmid harboring the $\triangle 6$-DES gene from the microalga M. pusilla was constructed and overexpressed in an uracil-auxotrophic strain of M. alpina, increasing EPA production by 26-fold [180]. Moreover, $\Delta 5-$ and $\triangle 6$-DES from P. tricornutum were cloned and characterized in Saccharomyces cerevisiae by Domergue et al. [179]. Using both desaturases in combination with P. patens $\triangle 6-E L O$, AA and EPA biosynthetic pathways were reconstituted in yeast, achieving an increase in AA and EPA in mutants [179]. Heterologous expression of P. tricornutum $\triangle 5$-ELO in the yeast Pichia pastoris allowed characterizing this enzyme capable of elongating AA and EPA [176]. Co-expression of P. tricornutum $\triangle 5$-ELO and Isochrysis sphaerica $\triangle 4$-DES (a desaturase that catalyses DTA conversion into DPA) to assemble the high-efficiency biosynthetic pathway of DHA in the transgenic yeast significantly increased DHA content [176]. Lu and co-authors [177] expressed $\triangle 2$-DES from the psychrotrophic Antarctic C. vulgaris in S. cerevisiae: The accumulation of $\triangle 2$-DES induced an interesting accumulation of linoleic acid content in expressing yeast, which was not present in wild-type strain [177].

\subsection{Enhancement of the TAG Biosynthetic Pathway}

In microalgae, TAGs are mostly biosynthesized by the ER-localized pathway. An alternative biosynthetic mechanism of plastidial origin was proposed in some microalgae, such as C. reinhardtii and P. tricornutum, and the resulting TAGs were found to be stored in lipid droplets in both cytosol and plastids $[91,190]$. The saturation and length properties of the FAs' acyl chain was determined by the substrate specificity of the acyltransferases of the de novo TAG biosynthetic pathway [91,191,192], so that altering it can improve PUFAs production [93].

Glycerol-sn-3-phosphate acyl-transferase (GPAT) catalyses the first reaction of TAG synthesis, esterifying the acyl-group from acyl-CoA to glycerol-3-phosphate (G3P), forming lysophosphatidate (Lyso-PTA) via the Kennedy pathway (Figure 2, sections 2 and 4). This enzyme was overexpressed in several microalgal species for its characterization and for its involvement in lipid metabolism. A GPAT was identified and functionally characterized in the diatom P. tricornutum. Its overexpression led to a significantly higher proportion of unsaturated FAs compared with the wild-type. EPA levels increased by 
$40 \%$, while those of $C_{16: 0}$ and monounsaturated FAs (MUFAs) decreased by $45 \%$ and $12 \%$, respectively [92]. Balamurugan et al. [91] identified AGPAT1 in P. tricornutum, localized on the plastid membrane in this species, whose overexpression significantly altered the primary metabolism, with increased total lipid content but decreased content of total carbohydrates and soluble proteins. P. tricornutum AGPAT1 overexpression coordinated also the expression of other key genes involved in TAG synthesis, increasing TAG content by 1.8-fold with a significant increase in PUFAs, particularly EPA and DHA by 1.5 -fold. Additionally, Jiang et al. [193] provided a method for increasing the lipid content, in particular TAG content, of diatom through GPAT overexpression in P. tricornutum. Another example is the heterologous expression of a GPAT gene from Lobosphaera incisa, which could reach up to 50\% TAG content, in C. reinhardtii, showing an increase in FA content by 1.5-fold [150].

Diacylglycerol acyl-transferase (DGAT) catalyzes the formation of TAG from diacylglycerol (DAG) and Acyl-CoA (Figure 2, sections 2 and 4). This reaction is the terminal step in TAG synthesis and it is essential for subsequent lipid droplets' formation. Niu et al. [93] showed that the overexpression of endogenous DGAT2 in P. tricornutum resulted in a 35\% increase in neutral lipid content and a 76\% increase in EPA content; the latter increase was also observed by Dinamarca et al. [94], along with a doubling in TAG content. Moreover, Zou et al. [99] used the strong constitutive promoter Pt211 to drive the expression of multiple target genes, such as GPAT and DGAT2, in P. tricornutum, resulting in a 2.7-fold increase in total lipids compared to the WT and a significant increase in EPA content, reaching up to $57.5 \%$ of dry cell weight. Yi and Xy [194] overexpressed a DGAT gene in N. oceanica to increase the specific PUFA content in TAGs. A heterologous expression plasmid containing the DGAT gene from C. reinhardtii was transformed into S. obliquus: This was the first report of successful genetic manipulation of S. obliquus to increase both biomass (that increased to $29 \%$ ) and lipid content (85\%) in S. obliquus [195]. In addition, the heterologous expression of DGAT2 from the plant Brassica napus in C. reinhardtii led to a decrease of total FAs, but enhanced the PUFA content, especially ALA, with an increase by up to $12 \%$ [156]. In another study, DGAT2 from S. cerevisiae was expressed in P. tricornutum to enhance TAG accumulation as well as to modify the FA composition in TAGs, in favour of high EPA levels [157]: Although TAG levels were enhanced by 2.3-fold, FA composition remained unchanged [157]. A DGAT1 gene derived from C. ellipsoidea was transformed in yeast, plant cells, and microalgae, obtaining an increase of the total FA content in the cells [196].

All the studies described here showed that GPAT and DGAT play a key role in lipid metabolism in microalgae. Overexpressing genes encoding for these two enzymes leads to a general increase in lipid content, with a different composition depending on the species engineered.

\subsection{Inhibition of Starch and Other Complex Polysaccharides' Biosynthesis}

A possible strategy to increase lipid accumulation consists of blocking competing pathways that lead to the accumulation of energy-rich storage compounds, such as starch and other complex polysaccharides, to enhance the metabolic flux channelling to lipid and FAs' biosynthesis [161]. In fact, starch is a major carbon and energy storage compound in many microalgae. The inactivation of ADP-glucose pyrophosphorylase (AGPase) (Figure 2, section 1) or of isoamylase by X-ray mutagenesis and UV mutagenesis in a Chlamydomonas starchless mutant led to a 3.5-fold increase in total lipid content and, for AGPase silencing, also to a 10-fold increase in TAG content, suggesting that the photosynthetic carbon from starch is driven towards TAG synthesis $[123,197]$. In diatoms, the fixed carbon is stored in vacuoles as chrysolaminarin, a water-soluble polysaccharide whose synthesis shares common carbon precursors with lipid synthesis. The effects of UDP-glucose pyrophosphorylase (UGPase) (Figure 2, section 1) suppression on chrysolaminarin biosynthesis and carbon allocation in P. tricornutum were investigated in two studies: Daboussi et al. [124] reported a 45-fold increase in TAG accumulation in the transgenic strains, generated through the disruption of the UGPase gene using TALEN, while Zhu et al. [125] demonstrated that 
silencing of UGPase through antisense or inverted repeats resulted in significant decreases in chrysolaminarin content and increases in lipid synthesis. On the other hand, antisense knockdown of the chrysolaminarin synthase gene in T. pseudonana cells reduced the accumulated chrysolaminarin and led to a 3-fold increase in TAG level, with minimal detriment to growth [126].

\subsection{Altering Pyruvate Metabolism}

The conversion of phosphoenolpyruvate (PEP) to oxaloacetate is catalyzed by phosphoenolpyruvate carboxylase (PEPC), which also plays a key role in photosynthesis [79] (Figure 2, section 5). FAs' biosynthesis requires PEP, which is successively converted to pyruvate, acetyl-CoA, malonyl-CoA, and then FAs. Previous studies showed that there was a negative correlation between the activities of PEPC, a key enzyme of the amino acid metabolic pathway, and lipid accumulation because PEPC and ACCase share a common substrate, pyruvate [198]. For this reason, the inhibition of the activity of PEPC may promote the flow of carbon from PEP to pyruvate and to Acetyl-CoA, generally to FAs synthesis, enhancing the oil content of cells [130]. Knockdown of PEPC1 in C. reinhardtii by the CRISPR/Cas9 system enhanced lipid content and lipid productivity by $74 \%$ and $94 \%$, respectively [128]. Similarly, knockdown of PEPC1 in C. reinhardtii by RNAi decreased PEPC activity by $39-50 \%$ and increased TAG level by $20 \%$ [129]. Using a multi-gene approach, the expression of two C. reinhardtii PEPC genes (PEPC1 and PEPC2) was down-regulated by amiRNA-mediated knockdown technology, resulting in a strong increase in FAs' content by $48 \%$ [130].

Pyruvate dehydrogenase (PDH), which catalyzes the conversion of pyruvate to acetyl$\mathrm{CoA}$, is under the control of pyruvate dehydrogenase kinase (PDK), which can phosphorylate and deactivate PDH (Figure 2, sections 1 and 5). PDH and PDK form the pyruvate dehydrogenase complex (PDC), an immediate primer for the initial reactions of de novo FAs' synthesis (Figure 2, sections 1 and 5). Therefore, with the same purpose of promoting the metabolic flow from pyruvate towards the conversion to Acetyl-CoA and consequently to the synthesis of a greater quantity of FAs, it is possible to remove the PDH inhibitor. Due to antisense knockdown of PDK, neutral lipid content of transgenic P. tricornutum cells increased up to $82 \%$ but without any change in FAs' content [132], while amiRNAmediated knockdown of $C$. reinhardtii $\mathrm{PDH}$ led to a 50\% decrease in FAs' content [143].

\subsection{Reducing Lipid Catabolism}

Engineering efforts focused on increasing lipid biosynthesis or blocking the competing pathways, such as carbohydrate formation, have successfully increased the lipid content [199], but they often resulted in engineered strains growing at lower rates than WTs $[122,161]$. An alternative strategy to increase lipid accumulation consists of inhibiting lipid catabolism. Lipid breakdown plays a key role in quickly providing acyl groups for membrane reorganization as environmental conditions change, contributing to polar lipid synthesis during dark cycles and remobilizing cell membranes upon release from nutrient stress [133]. Targeted knockdown of lipid catabolism, and specifically lipases, could potentially improve the accumulation of FAs and enhance lipid content with less impact on primary carbon pathways associated with growth [200].

Trentacoste and co-workers, using antisense RNAi constructs, successfully engineered T. pseudonana targeting an enzyme with lipase activity (Figure 2, section 5): This strategy resulted in an increase in TAG accumulation and total lipid yield without impacting growth rate, under both continuous light and alternating light/dark, continuous growth, and nutrient-replete versus nutrient-deficient conditions. FAs' analysis revealed that knockdown strains contained greater amounts of PA and LA than wild-type species, with a 4-fold increase in EPA and a 3.2-fold increase in DHA content [133]. In P. tricornutum, TGL1 (a putative TAG lipase) knockdown mutant strains were created using an antisense RNA approach, showing a strong increase of TAG and PUFA in the lipid extracts in the mutant cell lines [135]. Knockdown of an OmTGL lipase in P. tricornutum considerably enhanced 
neutral lipid content at the stationary growth phase, with TAGs increased by 1.4 folds and a 70\% increase in EPA content in the OmTGL RNAi lines [134]. Another possibility is to block some of the $\beta$-oxidation steps, as done by Kong et al. [137] in C. reinhardtii. The importance of peroxisomal FA $\beta$-oxidation in algal physiology was shown by the impact of the insertional mutation on FA turnover during day/night cycles and by the accumulation of $20 \%$ more oil under nitrogen depletion [137].

\subsection{Overexpression of Transcription Factors}

Transcription factors (TFs) bind to cis-acting elements in target gene promoters, controlling and regulating gene expression (Figure 2, section 6). TFs can be used as building blocks and regulatory tools in metabolic engineering and synthetic biology [201]. As an example, they can be engineered in host cells to control the expression of key enzymes in biosynthetic gene clusters [202].

Overexpression of DOF-type transcription factor genes in C. reinhardtii resulted in an increase of total lipids by ca. 2-fold [112]. Heterologous expression of DOF4 from soybean (Glycine max) significantly increased the lipid content of Chlorella ellipsoidea by $53 \%$ without growth inhibition [167]; such increase was attributed to the large number of genes with up-regulated expression, especially the ACCase gene [88,167]. TFs with the basic leucine zipper (bZIP) domain have been known as stress regulators and are associated with lipid metabolism in plants. Overexpression of a bZIP TF in N. salina resulted in enhanced growth with concomitant increase in lipid contents and phenotypes, also notable under stress conditions including $\mathrm{N}$ limitation and high salt [116]. Transcriptional engineering is a promising technique to enhance microalgal lipid production, in particular, altering the expression of multiple genes involved in the same metabolic pathway simultaneously [203]. Overexpression of phosphorus stress response-1 (PSR1) in C. reinhardtii can lead to changes in carbon storage metabolism through the control of specific genes involved in lipid and starch metabolisms. In detail, Overexpression of PSR1 can increase TAG accumulation without inhibiting the growth [115] or increasing starch biosynthesis, limiting neutral lipid accumulation [114,204]. Moreover, heterologous expression of three subunits of the transcription factor NF-Y from C. ellipsoidea in the plant $A$. thaliana, enhanced biomass production of $44.9-51 \%$ and total FAs' production of $11.2-15.4 \%[196,205,206]$. Lastly, Yang et al. [207] overexpressed a bHLH2 gene, encoding a basic helix-loop-helix transcription factor, in N. salina, enhancing lipid productivity and growth rate of microalgae by culturing it in a nitrogen-depleted medium and/or an osmosis stress medium. On the other hand, research by Ajjawi and co-workers represents the only example of TF knockout, obtained with the CRISPR/Cas9 method, which has shown effects on lipid production. Knockout of the homolog of fungal $\mathrm{Zn}(\mathrm{ii})_{2} \mathrm{Cys}_{6}$ encoding gene in $\mathrm{N}$. gaditana improved partitioning of total carbon to lipids from $20 \%$ (WT) to $40-55 \%$ (mutant) in nutrient-replete conditions, but with a strong growth reduction. In the same study, $\mathrm{Zn}(\mathrm{ii}){ }_{2} \mathrm{Cys}_{6}$ knockdown through RNAi increased twice as much lipid than in the WT, with little effect on growth [147].

As a metabolite sensor and gene expression regulator, TFs play an important role in determining the end product productivity in a cell factory. Therefore, the importance of $\mathrm{TFs}^{\prime}$ engineering is that it is a critical tool in optimizing phenotypes, as they are key components used to construct synthetic genetic circuits in vivo. However, the molecular mechanism, compatibility, robustness, and interaction of TFs in regulating metabolic networks in microalgae need to be understood and thoroughly elucidated to enhance the efficiency of TF-based strain development [208].

\section{Potential of Microalgae for Sustainable Aquaculture}

The global aquaculture production has been growing at an ever-increasing speed over the last two decades. This trend has been mostly driven by the increase in the world population as well as the 'nutrition transition' from a calorie-rich cereal diet to protein-rich meat diets that mostly include beef, poultry, pig, sheep, and fish. In particular, global 
demand for fish has significantly increased, on the basis of their $\omega-3$ FAs' proven health benefits. Dietary $\omega-3$ PUFAs play indeed crucial and physiologically complex roles in several key metabolic functions [209]. In this context, aquaculture is one of the strategies that can contribute to limit over-fishing of wild populations, although there are growing concerns about aquaculture feed sustainability [55].

The major issues of aquaculture feed production are the limited availability of feed ingredients and their booming prices, such that, to date, fish meal and fish oil have proved to be the best compromise between economic constraints and a healthy composition of the final product [210].

However, aquafeed includes ocean-derived ingredients extracted from 'forage' fishes such as small- and medium-sized pelagic fishes. Generally, one-sixth of global capture fisheries are rendered into fish meal and fish oil commodities despite $90 \%$ of these harvested fish being food-grade for human consumption [211]. This is one of the economic, environmental, and sustainability concerns that make the reliance on fish meal and oil to produce aquaculture feed a limiting factor [212].

Different alternatives have been proposed to supplement or replace fish meal in aquaculture feeds, such as fish processing waste and plant-based ingredients. The latter, however, still needs to be supplemented with essential amino acids like methionine and lysine [213] and can also contain anti-nutritional components that compromise digestion. In this context, microalgae would be a more suitable replacement, since they are a natural source of $\omega-3$ FAs and have a balanced amino acid profile [214]. To date, a variety of microalgal genera, such as Nannochloropsis, Phaeodactylum, Tetraselmis, and Isochrysis, have been extensively used in the aquaculture industry $[11,215,216]$. A list of recent research based on the application of microalgae-derived PUFAs as aquafeed is reported in Table 3.

Table 3. Microalgae and their derivatives used as feed in farming or aquaculture. The table includes microalgal species involved, application as feed, innovations, and nutritional values indicated as percentage increase respect to a basal diet.

\begin{tabular}{|c|c|c|c|c|}
\hline Microalgal Species & Application (as Feed or Food) & Innovation & $\begin{array}{c}\text { Nutritional Value } \\
\text { (Respect to Basal Diet) }\end{array}$ & Reference \\
\hline generic microalgae & $\begin{array}{l}\text { Feed for light lamb Ovis aries } \\
\text { farming }\end{array}$ & $\begin{array}{c}\text { mixed with extruded linseed } \\
\text { could, in part, replace } \\
\text { fish meat }\end{array}$ & $+520 \%$ ALA & [217] \\
\hline generic microalgae & $\begin{array}{l}\text { Feed for Pacific lamprey } \\
\text { Entosphenus tridentatus } \\
\text { aquaculture }\end{array}$ & $\begin{array}{l}\text { complete replacement of yeast } \\
+ \text { fish oil }\end{array}$ & $\begin{array}{l}+21 \% \text { total LC-PUFA; } \\
+9 \% \text { total } \omega 3 \text { PUFA; } \\
+11 \% \text { EPA }\end{array}$ & [218] \\
\hline Schizochytrium sp. & $\begin{array}{l}\text { Feed for Atlantic salmon Salmo } \\
\text { salar aquaculture }\end{array}$ & $\begin{array}{l}\text { complete replacement of } \\
\text { fish oil }\end{array}$ & $+100 \%$ DHA & [219] \\
\hline Schizochytrium sp. & $\begin{array}{l}\text { Feed for Nile tilapia } \\
\text { Oreochromis niloticus } \\
\text { aquaculture }\end{array}$ & $\begin{array}{l}\text { complete replacement of } \\
\text { fish meat }\end{array}$ & $\begin{array}{l}+23 \% \text { total PUFA; } \\
+30.2 \% \text { DHA }\end{array}$ & [220] \\
\hline Schizochytrium sp. & $\begin{array}{l}\text { Feed for tambaqui Colossoma } \\
\text { macropomum aquaculture }\end{array}$ & $\begin{array}{l}\text { complete replacement of } \\
\text { fish meat }\end{array}$ & $\begin{array}{c}+300 \% \text { total } \omega 3 \text { PUFA; } \\
+200 \% \text { PA; } \\
+126 \% \text { EPA; } \\
+51,200 \% \text { DHA; } \\
+512 \% \omega 3: \omega 6\end{array}$ & [221] \\
\hline Schizochytrium sp. & $\begin{array}{l}\text { Feed for Atlantic salmon Salmo } \\
\text { salar aquaculture }\end{array}$ & $\begin{array}{c}\text { the complete replacement } \\
\text { of fish }\end{array}$ & $\begin{array}{c}+6 \% \text { SFA; } \\
+3 \% \text { DHA; } \\
+1 \% \text { MUFA; } \\
+1 \% \text { total } \omega 6 \text { PUFA }\end{array}$ & [209] \\
\hline Schizochytrium sp. & $\begin{array}{c}\text { Feed for Rainbow Trout } \\
\text { Oncorhynchus mykiss } \\
\text { aquaculture }\end{array}$ & $\begin{array}{l}\text { complete replacement of } \\
\text { fish meat }\end{array}$ & $+18 \%$ total PUFA & [222] \\
\hline Schizochytrium sp. & $\begin{array}{l}\text { Feed for red seabream Pagrus } \\
\text { major aquaculture }\end{array}$ & $\begin{array}{l}\text { complete replacement of } \\
\text { fish meat }\end{array}$ & $\begin{array}{c}+130 \% \text { SFA; }+180 \% \text { PA; } \\
+100 \% \text { DHA; } \\
+2070 \% \text { DHA:EPA }\end{array}$ & [223] \\
\hline Schizochytrium sp. & $\begin{array}{l}\text { Feed for broiler chicken Gallus } \\
\text { domesticus farming }\end{array}$ & $0.2 \%$ Schiochytrium inclusion & $+2.5 \%$ total USFA & [224] \\
\hline
\end{tabular}


Table 3. Cont

\begin{tabular}{|c|c|c|c|c|}
\hline Microalgal Species & Application (as Feed or Food) & Innovation & $\begin{array}{c}\text { Nutritional Value } \\
\text { (Respect to Basal Diet) }\end{array}$ & Reference \\
\hline Schizochytrium sp. & $\begin{array}{l}\text { Feed for channel catfish } \\
\text { Ictalurus punctatus aquaculture }\end{array}$ & $+2 \%$ dried Schizochytrium & $\begin{array}{c}+3.71 \% \text { total } \omega 3 \\
\text { LC-PUFA; } \\
+3.35 \% \text { DHA }\end{array}$ & [225] \\
\hline Schizochytrium sp. & $\begin{array}{l}\text { Feed for shrimps Litopenaeus } \\
\text { vannamei aquaculture }\end{array}$ & $\begin{array}{c}\text { until } 75 \% \text { replacement of } \\
\text { fish meat }\end{array}$ & $\begin{array}{c}+100 \% \text { total } \omega 6 \text { PUFA; } \\
+200 \% \text { DHA }\end{array}$ & [226] \\
\hline Schizochytrium sp. & $\begin{array}{c}\text { Feed for light lamb Ovis aries } \\
\text { farming }\end{array}$ & $\begin{array}{c}3.8 \% \text { Schizochytrium and 5\% } \\
\text { linseed inclusion }\end{array}$ & $\begin{array}{r}+400 \% \text { ALA; } \\
+6500 \% \text { DHA }\end{array}$ & [227] \\
\hline Schizochytrium sp. & $\begin{array}{l}\text { Feed for rabbit Oryctolagus sp. } \\
\text { farming }\end{array}$ & 4 gr Schizochytrium per kg feed & $\begin{array}{c}+50 \% \text { EPA; } \\
+180 \% \text { DHA } \\
+2 \% \text { PA }\end{array}$ & [228] \\
\hline Schizochytrium sp. & $\begin{array}{l}\text { Feed for Atlantic salmon Salmo } \\
\text { salar aquaculture }\end{array}$ & $50 \%$ Schizochytrium inclusion & $\begin{array}{l}+22 \% \text { total } \omega 6 \text { PUFA; } \\
+15 \% \text { total PUFA; } \\
+340 \% \text { DHA:EPA }\end{array}$ & [229] \\
\hline $\begin{array}{l}\text { Schizochytrium } \\
\text { limacinum }\end{array}$ & $\begin{array}{l}\text { Feed for grouper Epinephelus } \\
\text { lanceolatus aquaculture }\end{array}$ & $\begin{array}{l}\text { in combination with soybean } \\
\text { meal, soy protein concentrate } \\
\text { could replace } 40 \% \text { of fish meat }\end{array}$ & $\begin{array}{c}+100 \% \text { DHA; } \\
+550 \% \text { DHA:EPA }\end{array}$ & [230] \\
\hline $\begin{array}{l}\text { Schizochytrium } \\
\text { limacinum }\end{array}$ & General aquaculture feed & $\begin{array}{l}48 \% v / v \text { effluent concentration } \\
\text { from biofuel industry }\end{array}$ & $\begin{array}{c}+80 \% \text { SA; } \\
+120 \% \text { DHA }\end{array}$ & [231] \\
\hline Aurantiochytrium sp. & $\begin{array}{l}\text { Feed for black tiger shrimp } \\
\text { Penaeus monodon aquaculture }\end{array}$ & $\begin{array}{l}\text { 1-2\% Aurantiochytrium } \\
\text { inclusion }\end{array}$ & $\begin{array}{c}+200 \% \text { total MUFA; } \\
+10 \% \text { total SFA; } \\
+12 \% \text { total PUFA; } \\
+20 \% \text { total } \omega 3 \text { PUFA; } \\
+37 \% \text { DHA }\end{array}$ & [232] \\
\hline Isochrysis sp. & $\begin{array}{c}\text { Feed for European seabass } \\
\text { Dicentrarchus labrax } \\
\text { aquaculture }\end{array}$ & $\begin{array}{l}20 \% \text { of protein and } 36 \% \text { of } \\
\text { lipid could be replaced using } \\
\text { the freeze-dried Isochrysis }\end{array}$ & $\begin{array}{l}+4 \% \text { total } \omega 3 \text { PUFA; } \\
\quad+13 \% \text { total SFA }\end{array}$ & [233] \\
\hline Isochrysis galbana & $\begin{array}{c}\text { Feed for silverfish Trachinotus } \\
\text { ovatus aquaculture }\end{array}$ & $24-26 \%$ fish oil replacement & $\begin{array}{l}+10 \% \text { DHA } ;+10 \% \text { total } \\
\text { LC- }-\omega 3 \text { PUFA }\end{array}$ & [234] \\
\hline $\begin{array}{l}\text { Phaeodactylum } \\
\text { tricornutum }\end{array}$ & $\begin{array}{l}\text { Feed for Atlantic salmon Salmo } \\
\text { salar aquaculture }\end{array}$ & $\begin{array}{l}\text { 6\% dried Phaeodactylum } \\
\text { inclusion }\end{array}$ & $\begin{array}{c}\text { same nutritional } \\
\text { content }\end{array}$ & [215] \\
\hline $\begin{array}{c}\text { Phaeodactylum } \\
\text { tricornutum or } \\
\text { Crypthecodinium } \\
\text { cohnii }\end{array}$ & $\begin{array}{l}\text { Feed for gilthead seabream } \\
\text { Sparus aurata aquaculture }\end{array}$ & $\begin{array}{l}2-5 \% \text { Crypthecodinium or } \\
\text { Phaeodactylum inclusion }\end{array}$ & $\begin{array}{l}+16 \% \text { total SFA; } \\
+20 \% \text { DHA }\end{array}$ & [235] \\
\hline $\begin{array}{l}\text { Haematococcus } \\
\text { pluvialis }\end{array}$ & $\begin{array}{l}\text { Feed for Rainbow Trout } \\
\text { Oncorhynchus mykiss } \\
\text { aquaculture }\end{array}$ & 10 gr Haematococcus per kg feed & - & [236] \\
\hline Staurosira sp. & $\begin{array}{c}\text { Feed for broiler chicken Gallus } \\
\text { domesticus farming } \\
\text { Feed for Nile tilapia }\end{array}$ & $7.5 \%$ Staurosira inclusion & $+25 \%$ total lipids & [237] \\
\hline Arthrospira platensis & $\begin{array}{c}\text { Oreochromis niloticus } \\
\text { aquaculture }\end{array}$ & $30 \%$ Arthrospira inclusion & - & [238] \\
\hline Spirulina platensis & $\begin{array}{l}\text { Feed for broiler chicken Gallus } \\
\text { domesticus farming }\end{array}$ & 10 gr Spirulina per kg feed & $\begin{array}{l}\text { same nutritional } \\
\text { content }\end{array}$ & [239] \\
\hline $\begin{array}{l}\text { Spirulina platensis or } \\
\text { Chlorella vulgaris }\end{array}$ & $\begin{array}{c}\text { Feed for African catfish Clarias } \\
\text { gariepinus aquaculture }\end{array}$ & $\begin{array}{l}\text { ultill } 75 \% \text { Spirulina or Chlorella } \\
\text { inclusion }\end{array}$ & $\begin{array}{l}+20 \% \text { total } \omega 6 \text { PUFA; } \\
+50 \% \text { DHA }\end{array}$ & [240] \\
\hline Chlorella sp. & $\begin{array}{c}\text { Feed for crucian carp Carassius } \\
\text { auratus aquaculture }\end{array}$ & $\begin{array}{l}\text { in combination with } 2 \text { gr } \\
\text { cellulases per } \mathrm{kg} \text { could } \\
\text { completely replace fish meat }\end{array}$ & - & [241] \\
\hline Chlorella spp. & $\begin{array}{l}\text { Feed for Channel Catfish } \\
\text { Ictalurus punctatus aquaculture }\end{array}$ & $15 \%$ Chlorella inclusion & $\begin{array}{c}+75 \% \text { PA } ;+30 \% \text { OA; } \\
+100 \% \text { EPA } ;+70 \% \\
\text { DHA; } \\
+32 \% \text { total } \omega 3 \text { PUFA }\end{array}$ & [242] \\
\hline $\begin{array}{c}\text { Chlorella sp. or } \\
\text { Nannochloropsis sp. }\end{array}$ & $\begin{array}{c}\text { Feed for European seabass } \\
\text { Dicentrarchus labrax } \\
\text { aquaculture }\end{array}$ & $\begin{array}{c}15 \% \text { Chlorella or } \\
\text { Nannochloropsis inclusion }\end{array}$ & $+2 \%$ total $\omega 6$ PUFA & [243] \\
\hline
\end{tabular}


Table 3. Cont

\begin{tabular}{|c|c|c|c|c|}
\hline Microalgal Species & Application (as Feed or Food) & Innovation & $\begin{array}{c}\text { Nutritional Value } \\
\text { (Respect to Basal Diet) }\end{array}$ & Reference \\
\hline $\begin{array}{l}\text { Nannochloropsis } \\
\text { gaditana }\end{array}$ & $\begin{array}{l}\text { Feed for Nile tilapia } \\
\text { Oreochromis niloticus } \\
\text { aquaculture }\end{array}$ & $30 \%$ Nannochloropsis inclusion & - & [244] \\
\hline $\begin{array}{l}\text { Nannochloropsis } \\
\text { gaditana }\end{array}$ & $\begin{array}{l}\text { Feed for gilthead seabream } \\
\text { Sparus aurata aquaculture }\end{array}$ & $2 \%$ Nannochloropsis inclusion & $\begin{array}{c}+80 \% \text { EPA; } \\
+200 \% \text { EPA:DHA }\end{array}$ & [245] \\
\hline Nannochloropsis sp. & $\begin{array}{c}\text { Feed for kuruma shrimp } \\
\text { Marsupenaeus japonicus } \\
\text { aquaculture }\end{array}$ & $\begin{array}{l}4-7-10 \% \text { Nannochloropsis } \\
\text { biomass or lipid inclusion }\end{array}$ & $\begin{array}{l}+13 \% \text { total } \omega 3 \text { PUFA; } \\
+44 \% \text { total } \omega 6 \text { PUFA; } \\
+37 \% \text { EPA }\end{array}$ & [246] \\
\hline Nannochloropsis sp. & $\begin{array}{c}\text { Feed for European seabass } \\
\text { Dicentrarchus labrax } \\
\text { aquaculture }\end{array}$ & $\begin{array}{c}5-10-15 \% \text { Nannochloropsis } \\
\text { inclusion }\end{array}$ & $\begin{array}{l}\text { same nutritional } \\
\text { content }\end{array}$ & [247] \\
\hline Nannochloropsis salina & $\begin{array}{l}\text { Feed for Nile tilapia } \\
\text { Oreochromis niloticus } \\
\text { aquaculture }\end{array}$ & $\begin{array}{l}\text { complete replacement of fish } \\
\text { meat }\end{array}$ & $\begin{array}{l}+47 \% \text { total } \omega 6 \text { PUFA; } \\
+130 \% \text { EPA }\end{array}$ & [248] \\
\hline $\begin{array}{l}\text { Nannochloropsis sp. or } \\
\text { Pavlova viridis }\end{array}$ & $\begin{array}{c}\text { Feed for European seabass } \\
\text { Dicentrarchus labrax } \\
\text { aquaculture }\end{array}$ & $\begin{array}{l}\text { complete replacement of fish } \\
\text { meat }\end{array}$ & $\begin{array}{l}+50 \% \text { total PUFA; }+70 \% \\
\text { total } \omega 6 \text { PUFA }\end{array}$ & [249] \\
\hline Pavlova lutheri & $\begin{array}{c}\text { Feed for oyster Crassostrea } \\
\text { gigas aquaculture }\end{array}$ & $\begin{array}{c}\text { complete replacement of fish } \\
\text { meat }\end{array}$ & - & [250] \\
\hline Tetraselmis suecica & $\begin{array}{l}\text { Feed for shrimps Litopenaeus } \\
\text { vannamei aquaculture }\end{array}$ & $\begin{array}{c}\text { complete replacement of fish } \\
\text { meat }\end{array}$ & - & [251] \\
\hline Tetraselmis chuii & $\begin{array}{l}\text { Feed for shrimps Litopenaeus } \\
\text { vannamei aquaculture }\end{array}$ & $50 \%$ Tetraselmis inclusion & $+2 \%$ total lipids & [252] \\
\hline Tetraselmis sp. & $\begin{array}{l}\text { Feed for gilthead seabream } \\
\text { Sparus aurata aquaculture }\end{array}$ & $10 \%$ Tetraselmis inclusion & same total lipids & [253] \\
\hline $\begin{array}{l}\text { Tetraselmis suecica or } \\
\text { Tisochrysis lutea }\end{array}$ & $\begin{array}{c}\text { Feed for European seabass } \\
\text { Dicentrarchus labrax } \\
\text { aquaculture }\end{array}$ & $\begin{array}{l}\text { combination of both } \\
\text { microalgae for a complete } \\
\text { replacement of fish meat }\end{array}$ & - & [254] \\
\hline Desmodesmus sp. & $\begin{array}{c}\text { Feed for Atlantic salmon Salmo } \\
\text { salar aquaculture }\end{array}$ & $20 \%$ Desmodesmus inclusion & - & [255] \\
\hline $\begin{array}{l}\text { Aurantiochytrium sp. } \\
\text { and Schizochytrium } \\
\text { sp. }\end{array}$ & $\begin{array}{l}\text { Feed for gilthead seabream } \\
\text { Sparus aurata aquaculture }\end{array}$ & $\begin{array}{l}\text { blend of poultry and one of } \\
\text { two algal oils }\end{array}$ & $\begin{array}{c}+200 \% \text { total } \omega 6 \\
\text { LC-PUFA; } \\
+3 \% \text { PA; } \\
+500 \% \text { DHA:EPA }\end{array}$ & [256] \\
\hline $\begin{array}{l}\text { Nannochloropsis } \mathrm{sp} \\
\text { Isochrysis } \mathrm{sp} \text {. and } \\
\text { Schizochytrium sp. }\end{array}$ & $\begin{array}{c}\text { Feed for Rainbow Trout } \\
\text { Oncorhynchus mykiss } \\
\text { aquaculture }\end{array}$ & $\begin{array}{l}\text { blend of three microalgae for a } \\
\text { complete replacement of fish } \\
\text { meat }\end{array}$ & $\begin{array}{c}+80 \% \text { total PUFA; } \\
+170 \% \text { total } \omega 6 \text { PUFA }\end{array}$ & [257] \\
\hline $\begin{array}{l}\text { Nannochloropsis sp. } \\
\text { and Schizochytrium sp }\end{array}$ & $\begin{array}{l}\text { Feed for Nile tilapia } \\
\text { Oreochromis niloticus } \\
\text { aquaculture }\end{array}$ & $\begin{array}{c}\text { Blend of both microalgae for a } \\
\text { complete replacement of fish } \\
\text { meat }\end{array}$ & $\begin{array}{c}+20 \% \mathrm{PA} ;+50 \% \mathrm{DHA} \\
+20 \% \text { total } \omega 6 \\
\text { LC-PUFA }\end{array}$ & [211] \\
\hline
\end{tabular}

The heterotrophic eukaryotic genus Schizochytrium seems to be particularly suitable as aquaculture food, since it can contain up to $58 \%$ of crude lipid and high concentrations of DHA [258]. Schizochytrium sp. is, indeed, a high-quality candidate for complete substitution of fish oil in juvenile Nile tilapia feeds, providing an innovative means to formulate and optimize the composition of tilapia juvenile feed while simultaneously raising feed efficiency of its aquaculture and further developing environmentally and socially sustainable aquafeeds [220]. Several studies were carried out in order to completely replace fish meal and/or fish oil with Schizochytrium as feed for Atlantic salmon [209,219], rainbow trout [222], tambaqui [221], and red seabream [223], but also as partial replacement or additional inclusion of control diets [226].

The genus Isochrysis spp. has been extensively used in aquaculture industry for several decades [259] and makes one of the most promising genera for aquaculture because of its high $\omega-3$ PUFAs content, which can reach up to $5.4 \%$ of dry biomass [234,260]. 
In some studies, Isochrysis spp. has been demonstrated to improve fish growth performance and lipid deposition and enhances total $\omega-3$ FAs, DHA, and EPA contents in fish muscle and liver $[233,234]$.

Another example is given by Arthrospira spp., cyanobacteria with substantial productivity (20-90 tons/ha/year) that have been cultured and used as food and feed supplements [261]. Arthrospira sp. was included in experimental diets of broiler chicken feed [239], as previously done for Staurosira sp. by Austic and co-workers [237], and, in diets for Nile tilapia, it improved feed utilization efficiency and enhanced the overall health status of Nile tilapia juveniles [238].

Because of the high nutritional value, the genus Chlorella has been used as a dietary protein source for marine and freshwater fishes to improve weight gain and carcass quality $[240,243]$. However, its use as aquafeed has been limited by the relatively high level of fibres, which would retard digestion and absorption of nutrients because of fish inability to excrete cellulase and efficiently use complex carbohydrates as energy sources [241,262].

Nannochloropsis spp. are known as a source of $\omega-3$ FAs that can be cultured with high productivity (33.6-84.0 tons/ha/year) [11,261]. Archibeque et al. [263] and Gbadamosi and Lupatsch [248] reported that Nannochloropsis produced favourable nutritional and health performances similar to fish meal and better than soybean meal in the diet of rabbits and Nile tilapia. Different species of Nannochloropsis were demonstrated to be successfully included in diets for crustaceans and fishes $[243,245]$ combined with other microalgae to create a blend that completely replaced fish meat $[211,257]$ or constituted it alone an aquafeed [249].

Moreover, the green algal genus Tetraselmis is among the most important live food species in marine aquaculture. Using it as complete replacement or partial inclusion in diets resulted in improved growth performances, increased appetite, and immunity enhancement due to the bioactive components, such as $\omega-3$ and $\omega-6$ FAs $[251,254]$.

It has been estimated that, within a few years, once microalgae production, harvesting, and biomass processing have been improved, the production costs of EPA and DHA from microalgae will be equivalent to that of fish oil [11].

\section{Extraction, Purification, and Stability of PUFAs}

To obtain the maximum PUFAs' yield from microalgal, an efficient extraction method has to be combined with an effective purification technique. To date, a complete process for PUFAs' isolation from microalgae has not been successfully established; so, the methods for extracting PUFAs from fish are currently being adapted [264].

Cell disruption is the first step of lipid extraction process. Several methods are suitable for cell disruption: bead milling, high-pressure homogenization, freeze drying, hydrodynamic cavitation [265], ultrasonication [266], microwave [267], pulsed electronic field [268], acid/ionic liquid/surfactant/algicidal treatments, osmotic chock [269], or hydrolytic enzymes $[270,271]$. Among these, the microwave oven method has been identified as the easiest and most effective in microalgae such as Botryococcus sp., Chlorella vulgaris, and Scenedesmus sp. [264,267]. According to Ryckebosch et al. [272], cell disruption might be not essential in some microalgal species, and the wet biomass can be directly suspended in the extraction solvent, where cell wall is naturally degraded. Therefore, physico-chemical properties of specific microalgae have to be taken into account to establish if cell disruption is a necessary step or can be avoided.

Subsequently, lipids can be extracted with different solvent methods. The basic principle is the separation of the homogenate in different phases, which can be isolated. Specifically, an organic solvent penetrates through the cell membrane and interacts with the lipids forming solvent-lipids complexes, which diffuse across the cell membrane and across the static organic solvent into the bulk organic solvent [273]. In this context, the solvent composition is a key factor influencing solvent extraction. The most popular lipid extraction protocol was assessed more than 60 years ago by Folch and co-workers [274]. This method was initially settled for the extraction and subsequent purification of lipids from animal 
tissues, but was found suitable for other kinds of samples, including wet and dry microalgal biomass. Unfortunately, this technique is based on the use of a 2:1 chloroform: methanol solvent mixture, so it foresees a high amount of toxic solvents. A fast lipid recovery can be also obtained with methyl-tert-butyl ether (MTBE)/methanol, which avoids the use of a toxic solvent such as chloroform, allowing comparable or better lipid yields of the Folch method [275]. Recently, Li et al. [264] reviewed all the methods applied for EPA and DHA from microalgae, concluding that chloroform/methanol/water, hexane $/ 96 \%$ ethanol, $96 \%$ butanol $/ 96 \%$ ethanol/water, and $n$-hexane/isopropanol were found to be effective for lipid extraction.

Solvent extraction techniques are characterised by high yields of lipids obtained from microalgae, but often require more subsequent purification steps to eliminate as much solvent as possible from the final product. The use of solvents can be, indeed, unsuitable to extract products for pharmaceutical and food industrial sectors. Recently, new solvent-free lipid extraction methods have been developed, such as supercritical fluid extraction (SFE). This technique uses supercritical fluids—of which the most used is $\mathrm{CO}_{2}$ - which are a composite form of gas and liquid properties, existing above a critical temperature and pressure [276]. Supercritical $\mathrm{CO}_{2}$ is chemically inert, safe, low cost, nontoxic, and it is environmentally feasible with no access to organic solvents, allowing a greater purity of the final product [277]. Moreover, this process overcomes one of the biggest disadvantages of other methods, which is the degradation of extracts, by providing a non-oxidizing environment, and the low critical temperature (around $31^{\circ} \mathrm{C}$ ) also prevents the thermal degradation of extract [278].

Many PUFAs are widely applied in the health and pharmaceutical fields, so they need high purity levels, which can be reached through purification and/or enrichment techniques. Depending upon carbon chain length and degree of unsaturation, different methods are applied to enrich and purify of PUFAs [273]. They include winterization, molecular distillation, enzymatic purification, low-temperature crystallization, purification by urea inclusion, chromatographic separation, and supercritical fluid fractioning [264]. These different methods can be often combined to get the higher yield and extraction efficiency of PUFAs from microalgae. For example, Mendes and co-workers [279] developed a procedure to concentrate DHA from C. cohnii involving saponification and methylation in wet biomass for further winterization and urea complexation, reaching a $99.2 \%$ yield of total FAs.

Purity and composition of the microalgal oils are important, but these should also be stable during storage. In fact, PUFAs are easily oxidized, leading to off-flavors, a decrease of the nutritional value, and even formation of potentially toxic compounds [280]. Moreover, PUFAs are susceptible to chemical modifications, such as metal-catalyzed autoxidation and hydrogenation, because of their multiple carbon-carbon double bonds vulnerable to electrophilic attack [24]. Chen and co-authors [281] showed that storage of microalgal biomass leads to lipid hydrolysis, in particular when stored as a wet paste at temperatures above the freezing point, but sometimes also as spray- and freeze-dried microalgal biomass [272]. Ryckebosch et al. [280] investigated both the primary and secondary oxidation, highlighting that microalgae oils were more oxidatively stable than fish oils, probably due to the presence of more polar antioxidants such as polyphenols in microalgae. The authors also stated that the oxidative stability of the microalgae oils was also shown to be dependent on the solvent used to extract lipids. However, little is known about presence of hydrolytic enzymes in the extracts, so further research on oxidation of microalgae extracts is definitely needed.

\section{Summary, Conclusions, and Perspectives}

The main purpose of this review article was to highlight the potential of microalgaederived lipids as sustainable sources or food and feed. Modulation of nutrient supply (typology and/or concentrations in culture media) and of physical parameters (temperature, light, irradiance) can enhance the yields of specific lipids; culturing conditions that 
maximise production and/or productivity of highly valuable lipids can be species-specific, and, in some cases, specific growth strategies (such as a two-stage cultivation system) are required to maximise both biomass and lipid content.

Genetic and metabolic engineering were other useful tools to enhance lipid production (especially unsaturated ones) and include different strategies. Among them, improving some steps of the lipid biosynthetic pathway, turning off competitive metabolic pathways, or decreasing lipid catabolism are the most investigated strategies to increase lipid production, modifying their quantities as well as their composition. All previously discussed studies reported encouraging results, acting on different key enzymes and microalgal species, allowing the identification of promising target genes and organisms for subsequent research. These studies allowed us also to better understand the metabolic pathways that regulate lipid metabolism, for example, shedding light on enzymes not yet functionally characterized. Another winning strategy but still being explored is the manipulation of transcription factors, able to regulate different metabolic pathways at the same time and therefore able to act on multiple levels.

Currently, large-scale production of microalgae-derived lipidic commodities for food and feed industries is mostly based on cultivation in open ponds, since they represent the most economical alternative for massive growth. On the other hand, closed photobioreactors should be intended for final products requiring high quality levels and very low or null concentrations of contaminants, such as nutraceuticals and pharmaceuticals, but their rigid condition control is still very expensive. An interesting strategy to alleviate them is to first extract their lipids for the production of biodiesel, due to their high lipid contents, and then process the remainder lipid-free material as protein- and fatty acid-rich products [282,283]. Finally, we believe that a further effort to decrease operational costs through sustainable processes and nutrient recycle is required by phycological research.

An additional advantage of indoor photobioreactors compared to outdoor open ponds lies on the strict regulations on genetically modified organisms, including microalgae. Genetic engineering of microalgae contributed to improve specific biochemical features of some species, and culturing the resulting mutants rather than the corresponding wild types proved to be more economically viable. Since the accidental introduction of genetically modified microalgae in the environments can lead to dramatic consequences, comparable to those caused by some allochtonous species, legislation does not allow outdoor cultivation of such organisms in most countries. In contrast, genetically modified microalgae could be safely cultured in indoor systems, guaranteeing an aseptic separation between the inner and the outer environment is provided.

In this context, microalgal production of PUFAs has great development opportunities, but at the same time needs to face some key challenges: technical breakthroughs, access to venture capital and regulatory, academic and industrial training with co-operation between them, and reduction of biomass production cost. Although commercial-scale cultivation of microalgae is quickly improving, production costs of microalgal biomass is yet far from competitive. The main reasons behind the large production costs are related to the little proportions of PUFAs within microalgal biomass, which may depend on the cell growth and on the extraction methods.

In conclusion, PUFAs are well known to contribute to human health and well-being. These molecules, with different applications such as food and feed, are often obtained from fish which, due to the constant increase in demand, is less and less a sustainable source. Microalgae have been identified as currently the most sustainable and environmentally safe source to be exploited for the production of PUFAs for human consumption, as well as for feeding terrestrial and aquatic animals. However, the world has not yet fully exploited this potential, as other sources of PUFAs are still more economically advantageous, with already optimized production and extraction methods and high yields. Therefore, research in microalgal biotechnologies should focus on searching for novel strategies to minimize production costs and to increase the lipid yields, in the coming decade. Different aspects can be addressed to make microalgal production viable at an industrial scale, such as 
optimization of growth conditions, upstream processing to increase PUFAs productivities and selecting between different downstream processing to decrease production costs.

Author Contributions: A.S. (Anna Santin), A.S. (Angela Sardo) and M.I.F.: conceptualization; A.S. (Anna Santin) and A.S. (Angela Sardo): original draft preparation; S.B., M.T.R., I.O. and M.I.F.: review; A.S. (Anna Santin), I.O. and A.S. (Angela Sardo): table and figure preparation; A.S. (Angela Sardo): supervision. All authors have read and agreed to the published version of the manuscript.

Funding: This research received no external funding.

Institutional Review Board Statement: Not applicable.

Informed Consent Statement: Not applicable.

Acknowledgments: The authors are grateful to G. Lanzotti (SZN, Research Infrastructures for Marine biological Resources, RIMAR) for graphical support. A.S. (Anna Santin) has been supported by a PhD fellowship funded by the Stazione Zoologica Anton Dohrn (Open University-Stazione Zoologica Anton Dohrn PhD Program). Thanks are due also to the referees, who greatly contributed to improve the quality of the manuscript with their suggestions.

Conflicts of Interest: The authors declare no conflict of interest.

\section{References}

1. Ananthi, V.; Raja, R.; Carvalho, I.S.; Brindhadevi, K.; Pugazhendhi, A.; Arun, A. A realistic scenario on microalgae based biodiesel production: Third generation biofuel. Fuel 2021, 284, 118965. [CrossRef]

2. D'Ippolito, G.; Sardo, A.; Paris, D.; Vella, F.M.; Adelfi, M.G.; Botte, P.; Gallo, C.; Fontana, A. Potential of lipid metabolism in marine diatoms for biofuel production. Biotechnol. Biofuels 2015, 8, 10. [CrossRef] [PubMed]

3. Farahin, A.W.; Yusoff, F.M.; Basri, M.; Nagao, N.; Shariff, M. Use of microalgae: Tetraselmis tetrathele extract in formulation of nanoemulsions for cosmeceutical application. J. Appl. Phycol. 2019, 31, 1743-1752. [CrossRef]

4. Morocho-Jacome, A.L.; Ruscinc, N.; Martinez, R.M.; de Carvalho, J.C.M.; de Almeida, T.S.; Rosado, C.; Costa, J.G.; Velasco, M.V.R.; Baby, A.R. (Bio)technological aspects of microalgae pigments for cosmetics. Appl. Microbiol. Biotechnol. 2020, 104, $9513-9522$. [CrossRef] [PubMed]

5. Lauritano, C.; Andersen, J.H.; Hansen, E.; Albrigtsen, M.; Escalera, L.; Esposito, F.; Helland, K.; Hanssen, K.Ø.; Romano, G.; Ianora, A. Bioactivity screening of microalgae for antioxidant, anti-inflammatory, anticancer, anti-diabetes, and antibacterial activities. Front. Mar. Sci. 2016, 3, 68. [CrossRef]

6. Jimenez, R.; Markou, G.; Tayibi, S.; Barakat, A.; Chapsal, C.; Monlau, F. Production of microalgal slow-release fertilizer by valorizing liquid agricultural digestate: Growth experiments with tomatoes. Appl. Sci. 2020, 10, 3890. [CrossRef]

7. Uysal, O.; Uysal, F.O.; Ekinci, K. Evaluation of microalgae as microbial fertilizer. Eur. J. Sustain. Dev. 2015, 4, 77-82. [CrossRef]

8. Chandrashekharaiah, P.; Sanyal, D.; Dasgupta, S.; Banik, A. Cadmium biosorption and biomass production by two freshwater microalgae Scenedesmus acutus and Chlorella pyrenoidosa: An integrated approach. Chemosphere 2021, 269, 128755. [CrossRef]

9. Hena, S.; Gutierrez, L.; Croue, J.P. Removal of pharmaceutical and personal care products (PPCPs) from wastewater using microalgae: A review. J. Hazard. Mater. 2021, 403, 124041. [CrossRef]

10. Ferrazzano, G.F.; Papa, C.; Pollio, A.; Ingenito, A.; Sangianantoni, G.; Cantile, T. Cyanobacteria and microalgae as sources of functional foods to improve human general and oral health. Molecules 2020, 25, 5164. [CrossRef]

11. Chauton, M.S.; Reitan, K.I.; Norsker, N.H.; Tveteras, R.; Kleivdal, H.T. A techno-economic analysis of industrial production of marine microalgae as a source of EPA and DHA-rich raw material for aquafeed: Research challenges and possibilities. Aquaculture 2015, 436, 95-103. [CrossRef]

12. Chandra, R.; Iqbal, H.M.N.; Vishal, G.; Lee, H.S.; Nagra, S. Algal biorefinery: A sustainable approach to valorize algal-based biomass towards multiple product recovery. Bioresour. Technol. 2019, 278, 346-359. [CrossRef] [PubMed]

13. ElMekawy, A.; Hegab, H.M.; Mohanakrishna, G.; Elbaz, A.F.; Bulut, M.; Pant, D. Technological advances in $\mathrm{CO}_{2}$ conversion electro-biorefinery: A step toward commercialization. Bioresour. Technol. 2016, 215, 357-370. [CrossRef]

14. Menetrez, M.Y. An overview of algae biofuel production and potential environmental impact. Environ. Sci. Technol. 2012, 46, 7073-7085. [CrossRef] [PubMed]

15. Dębowski, M.; Zieliński, M.; Kazimierowicz, J.; Kujawska, N.; Talbierz, S. Microalgae cultivation technologies as an opportunity for bioenergetic system development-Advantages and limitations. Sustainability 2020, 12, 9980. [CrossRef]

16. Rosch, C.; Rossmann, M.; Weickert, S. Microalgae for integrated food and fuel production. GCB Bioenergy 2019, 11, 326-334. [CrossRef]

17. Bhola, V.; Swalaha, F.; Kumar, R.R.; Singh, M.; Bux, F. Overview of the potential of microalgae for $\mathrm{CO}_{2}$ sequestration. Int. J. Environ. Sci. Technol. 2014, 11, 2103-2118. [CrossRef] 
18. Botte, P.; d'Ippolito, G.; Gallo, C.; Sardo, A.; Fontana, A. Combined exploitation of $\mathrm{CO}_{2}$ and nutrient replenishment for increasing biomass and lipid productivity of the marine diatoms Thalassiosira weissflogii and Cyclotella cryptica. J. Appl. Phycol. 2018, 30, 243-251. [CrossRef]

19. Sepulveda, C.; Gomez, C.; Bahraoui, N.E.L.; Acien, G. Comparative evaluation of microalgae strains for $\mathrm{CO}_{2}$ capture purposes. J. $\mathrm{CO}_{2}$ Util. 2019, 30, 158-167. [CrossRef]

20. Van den Hende, S.; Vervaeren, H.; Boon, N. Flue gas compounds and microalgae: (Bio-)chemical interactions leading to biotechnological opportunities. Biotechnol. Adv. 2012, 30, 1405-1424. [CrossRef] [PubMed]

21. Chew, K.W.; Yap, J.Y.; Show, P.L.; Suan, N.H.; Juan, J.C.; Ling, T.C.; Lee, D.J.; Chang, J.S. Microalgae biorefinery: High value products perspectives. Bioresour. Technol. 2017, 229, 53-62. [CrossRef]

22. Kapoor, B.; Kapoor, D.; Gautam, S.; Singh, R.; Bhardwaj, S. Dietary polyunsaturated fatty acids (PUFAs): Uses and potential health benefits. Curr. Nutr. Rep. 2021, 10, 232-242. [CrossRef]

23. Mason, R.P.; Libby, P.; Bhatt, D.L. Emerging mechanisms of cardiovascular protection for the Omega-3 fatty acid eicosapentaenoic acid. Arterioscler. Thromb. Vasc. Biol. 2020, 40, 1135-1147. [CrossRef] [PubMed]

24. Saini, R.K.; Prasad, P.; Sreedhar, R.V.; Akhilender Naidu, K.; Shang, X.; Keum, Y.-S. Omega-3 polyunsaturated fatty acids (PUFAs): Emerging plant and microbial sources, oxidative stability, bioavailability, and health benefits-A review. Antioxidants 2021, 10, 1627. [CrossRef]

25. Ghasemi Fard, S.; Wang, F.L.; Sinclair, A.J.; Elliott, G.; Turchini, G.M. How does high DHA fish oil affect health? A systematic review of evidence. Crit. Rev. Food Sci. Nutr. 2019, 59, 1684-1727. [CrossRef] [PubMed]

26. Khozin-Goldberg, I.; Iskandarov, U.; Cohen, Z. LC-PUFA from photosynthetic microalgae: Occurrence, biosynthesis, and prospects in biotechnology. Appl. Microbiol. Biotechnol. 2011, 91, 905-915. [CrossRef]

27. Makrides, M.; Gibson, R.A. Are long-chain polyunsaturated fatty acids essential nutrients in infancy? In Proceedings of the 4th International Congress on Essential Fatty Acids and Eicosanoids, Edinburgh, UK, 20-24 July 1997; pp. 136-140.

28. Simopoulos, A.P. An increase in the Omega-6/Omega-3 fatty acid ratio increases the risk for obesity. Nutrients 2016, 8, 128. [CrossRef] [PubMed]

29. Yates, C.M.; Calder, P.C.; Rainger, G.E. Pharmacology and therapeutics of omega-3 polyunsaturated fatty acids in chronic inflammatory disease. Pharmacol. Ther. 2014, 141, 272-282. [CrossRef]

30. Abedi, E.; Sahari, M.A. Long-chain polyunsaturated fatty acid sources and evaluation of their nutritional and functional properties. Food Sci. Nutr. 2014, 2, 443-463. [CrossRef]

31. Klinger, D.; Naylor, R. Searching for solutions in aquaculture: Charting a sustainable course. Annu. Rev. Environ. Resour. 2012, 37, 247-276. [CrossRef]

32. Qi, S.B.; Zhao, X.W.; Zhang, W.J.; Wang, C.H.; He, M.L.; Chang, Y.Q.; Ding, J. The effects of 3 different microalgae species on the growth, metamorphosis and MYP gene expression of two sea urchins, Strongylocentrotus intermedius and S. nudus. Aquaculture 2018, 492, 123-131. [CrossRef]

33. Leal, E.; de Beyer, L.; O'Connor, W.; Dove, M.; Ralph, P.J.; Pernice, M. Production optimisation of Tisochrysis lutea as a live feed for juvenile Sydney rock oysters, Saccostrea glomerata, using large-scale photobioreactors. Aquaculture 2021, 533, 736077. [CrossRef]

34. Gachelin, M.; Boutoute, M.; Carrier, G.; Talec, A.; Pruvost, E.; Guiheneuf, F.; Bernard, O.; Sciandra, A. Enhancing PUFA-rich polar lipids in Tisochrysis lutea using adaptive laboratory evolution (ALE) with oscillating thermal stress. Appl. Microbiol. Biotechnol. 2021, 105, 301-312. [CrossRef]

35. Jethani, H.; Patel, P.; Mudliar, S.N.; Sarada, R.; Chauhan, V.S. Growth and biochemical response of an indigenous oleaginous microalga Scenedesmus obtusus cultivated in outdoor open ponds. Indian J. Exp. Biol. 2019, 57, 40-49.

36. Almeyda, M.D.; Bilbao, P.G.S.; Popovich, C.A.; Constenla, D.; Leonardi, P.I. Enhancement of polyunsaturated fatty acid production under low-temperature stress in Cylindrotheca closterium. J. Appl. Phycol. 2020, 32, 989-1001. [CrossRef]

37. Pasquet, V.; Ulmann, L.; Mimouni, V.; Guiheneuf, F.; Jacquette, B.; Morant-Manceau, A.; Tremblin, G. Fatty acids profile and temperature in the cultured marine diatom Odontella aurita. J. Appl. Phycol. 2014, 26, 2265-2271. [CrossRef]

38. Chang, J.Y.; Le, K.; Song, X.Q.; Jiao, K.L.; Zeng, X.H.; Ling, X.P.; Shi, T.; Tang, X.; Sun, Y.; Lin, L. Scale-up cultivation enhanced arachidonic acid accumulation by red microalgae Porphyridium purpureum. Bioprocess Biosyst. Eng. 2017, 40, 1763-1773. [CrossRef]

39. Qiao, H.J.; Cong, C.; Sun, C.X.; Li, B.S.; Wang, J.Y.; Zhang, L.M. Effect of culture conditions on growth, fatty acid composition and DHA/EPA ratio of Phaeodactylum tricornutum. Aquaculture 2016, 452, 311-317. [CrossRef]

40. Krishnan, A.; Ananda, R.; Joseph, A. Culture medium and growth phase modulate the fatty acid composition of the diatom Nitzschia palea (Kutzing) W. Smith-Potential source for live feed and biodiesel. Fish. Technol. 2020, 57, 28-35.

41. Fakhry, E.M.; El Maghraby, D.M. Lipid accumulation in response to nitrogen limitation and variation of temperature in Nannochloropsis salina. Bot. Stud. 2015, 56, 6. [CrossRef] [PubMed]

42. Solovchenko, A.E.; Gorelova, O.A.; Baulina, O.I.; Selyakh, I.O.; Semenova, L.R.; Chivkunova, O.B.; Scherbakov, P.N.; Lobakova, E.S. Physiological plasticity of symbiotic Desmodesmus (Chlorophyceae) isolated from taxonomically distant white sea invertibrates. Russ. J. Plant Physiol. 2015, 62, 653-663. [CrossRef]

43. Schreiber, C.; Behrendt, D.; Huber, G.; Pfaff, C.; Widzgowski, J.; Ackermann, B.; Muller, A.; Zachleder, V.; Moudrikova, S.; Mojzes, P.; et al. Growth of algal biomass in laboratory and in large-scale algal photobioreactors in the temperate climate of western Germany. Bioresour. Technol. 2017, 234, 140-149. [CrossRef] [PubMed] 
44. Pal, D.; Khozin-Goldberg, I.; Cohen, Z.; Boussiba, S. The effect of light, salinity, and nitrogen availability on lipid production by Nannochloropsis sp. Appl. Microbiol. Biotechnol. 2011, 90, 1429-1441. [CrossRef]

45. Su, C.-H.; Chien, L.-J.; Gomes, J.; Lin, Y.-S.; Yu, Y.; Liou, J.S.; Syu, R.-J. Factors affecting lipid accumulation by Nannochloropsis oculata in a two-stage cultivation process. J. Appl. Phycol. 2010, 23, 903-908. [CrossRef]

46. Guedes, A.C.; Meireles, L.A.; Amaro, H.M.; Malcata, F.X. Changes in lipid class and fatty acid composition of cultures of Pavlova lutheri, in response to light intensity. J. Am. Oil Chem. Soc. 2010, 87, 791-801. [CrossRef]

47. Wang, X.X.; Fosse, H.K.; Li, K.S.; Chauton, M.S.; Vadstein, O.; Reitan, K.I. Influence of nitrogen limitation on lipid accumulation and EPA and DHA content in four marine microalgae for possible use in aquafeed. Front. Mar. Sci. 2019, 6, 95. [CrossRef]

48. Breuer, G.; Lamers, P.P.; Martens, D.E.; Draaisma, R.B.; Wijffels, R.H. The impact of nitrogen starvation on the dynamics of triacylglycerol accumulation in nine microalgae strains. Bioresour. Technol. 2012, 124, 217-226. [CrossRef]

49. Li, T.; Xu, J.; Wu, H.B.; Jiang, P.L.; Chen, Z.S.; Xiang, W.Z. Growth and biochemical composition of Porphyridium purpureum SCS-02 under different nitrogen concentrations. Mar. Drugs 2019, 17, 124. [CrossRef]

50. Su, G.M.; Jiao, K.L.; Li, Z.; Guo, X.Y.; Chang, J.Y.; Ndikubwimana, T.; Sun, Y.; Zeng, X.H.; Lu, Y.H.; Lin, L. Phosphate limitation promotes unsaturated fatty acids and arachidonic acid biosynthesis by microalgae Porphyridium purpureum. Bioprocess Biosyst. Eng. 2016, 39, 1129-1136. [CrossRef]

51. Khozin-Goldberg, I.; Cohen, Z. The effect of phosphate starvation on the lipid and fatty acid composition of the fresh water eustigmatophyte Monodus subterraneus. Phytochemistry 2006, 67, 696-701. [CrossRef]

52. Sabu, S.; Singh, I.S.B.; Joseph, V. Improved lipid production in oleaginous brackish diatom Navicula phyllepta MACC8 using two-stage cultivation approach. 3 Biotech 2019, 9, 437. [CrossRef] [PubMed]

53. Gao, G.; Wu, M.; Fu, Q.Q.; Li, X.S.; Xu, J.T. A two-stage model with nitrogen and silicon limitation enhances lipid productivity and biodiesel features of the marine bloom-forming diatom Skeletonema costatum. Bioresour. Technol. 2019, 289, 121717. [CrossRef]

54. Boelen, P.; van Mastrigt, A.; van de Bovenkamp, H.H.; Heeres, H.J.; Buma, A.G.J. Growth phase significantly decreases the DHA-to-EPA ratio in marine microalgae. Aquac. Int. 2017, 25, 577-587. [CrossRef]

55. Adarme-Vega, T.C.; Thomas-Hall, S.R.; Lim, D.K.Y.; Schenk, P.M. Effects of long chain fatty acid synthesis and associated gene expression in microalga Tetraselmis sp. Mar. Drugs 2014, 12, 3381-3398. [CrossRef]

56. Dammak, M.; Haase, S.M.; Miladi, R.; Ben Amor, F.; Barkallah, M.; Gosset, D.; Pichon, C.; Huchzermeyer, B.; Fendri, I.; Denis, M.; et al. Enhanced lipid and biomass production by a newly isolated and identified marine microalga. Lipids Health Dis. 2016, 15, 209. [CrossRef]

57. Martinez-Roldan, A.J.; Perales-Vela, H.V.; Canizares-Villanueva, R.O.; Torzillo, G. Physiological response of Nannochloropsis sp. to saline stress in laboratory batch cultures. J. Appl. Phycol. 2014, 26, 115-121. [CrossRef]

58. Balzano, S.; Villanueva, L.; de Bar, M.; Sinninghe Damsté, J.S.; Schouten, S. Impact of culturing conditions on the abundance and composition of long chain alkyl diols in species of the genus Nannochloropsis. Org. Geochem. 2017, 108, 9-17. [CrossRef]

59. Rearte, T.A.; Figueroa, F.L.; Gomez-Serrano, C.; Velez, C.G.; Marsili, S.; Iorio, A.D.; Gonzalez-Lopez, C.V.; Ceron-Garcia, M.C.; Abdala-Diaz, R.T.; Acien-Fernandez, F.G. Optimization of the production of lipids and carotenoids in the microalga Golenkinia aff. brevispicula. Algal Res. Biomass Biofuels Bioprod. 2020, 51, 102004. [CrossRef]

60. Cepak, V.; Pribyl, P.; Kohoutkova, J.; Kastanek, P. Optimization of cultivation conditions for fatty acid composition and EPA production in the eustigmatophycean microalga Trachydiscus minutus. J. Appl. Phycol. 2014, 26, 181-190. [CrossRef]

61. Atikij, T.; Syaputri, Y.; Iwahashi, H.; Praneenararat, T.; Sirisattha, S.; Kageyama, H.; Waditee-Sirisattha, R. Enhanced lipid production and molecular dynamics under salinity stress in green microalga Chlamydomonas reinhardtii (137C). Mar. Drugs 2019, 17, 484. [CrossRef]

62. Conceicao, D.; Lopes, R.G.; Derner, R.B.; Cella, H.; do Carmo, A.P.B.; D’Oca, M.G.M.; Petersen, R.; Passos, M.F.; Vargas, J.V.C.; Galli-Terasawa, L.V.; et al. The effect of light intensity on the production and accumulation of pigments and fatty acids in Phaeodactylum tricornutum. J. Appl. Phycol. 2020, 32, 1017-1025. [CrossRef]

63. Russo, G.L.; Langellotti, A.L.; Oliviero, M.; Sacchi, R.; Masi, P. Sustainable production of food grade omega-3 oil using aquatic protists: Reliability and future horizons. New Biotechnol. 2021, 62, 32-39. [CrossRef] [PubMed]

64. Perez-Garcia, O.; Bashan, Y. Microalgal heterotrophic and mixotrophic culturing for bio-refining: From metabolic routes to techno-economics. In Algal Biorefineries: Products and Refinery Design; Prokop, A., Bajpai, R.K., Zappi, M.E., Eds.; Springer: Cham, Switzerland, 2015; pp. 61-131.

65. Zhu, L.Y.; Zhang, X.C.; Ji, L.; Song, X.J.; Kuang, C.H. Changes of lipid content and fatty acid composition of Schizochytrium limacinum in response to different temperatures and salinities. Process Biochem. 2007, 42, 210-214. [CrossRef]

66. Barone, R.; De Napoli, L.; Mayol, L.; Paolucci, M.; Volpe, M.G.; D’Elia, L.; Pollio, A.; Guida, M.; Gambino, E.; Carraturo, F.; et al. Autotrophic and heterotrophic growth conditions modify biomolecole production in the microalga Galdieria sulphuraria (Cyanidiophyceae, Rhodophyta). Mar. Drugs 2020, 18, 169. [CrossRef]

67. Cupo, A.; Landi, S.; Morra, S.; Nuzzo, G.; Gallo, C.; Manzo, E.; Fontana, A.; D’Ippolito, G. Autotrophic vs. heterotrophic cultivation of the marine diatom Cyclotella cryptica for EPA production. Mar. Drugs 2021, 19, 355. [CrossRef]

68. Selvakumar, P.; Umadevi, K. Enhanced lipid and fatty acid content under photoheterotrophic condition in the mass cultures of Tetraselmis gracilis and Platymonas convolutae. Algal Res. Biomass Biofuels Bioprod. 2014, 6, 180-185. [CrossRef]

69. Oliver, L.; Dietrich, T.; Maranon, I.; Villaran, M.C.; Barrio, R.J. Producing Omega-3 polyunsaturated fatty acids: A review of sustainable sources and future trends for the EPA and DHA market. Resources 2020, 9, 148. [CrossRef] 
70. Rawat, I.; Ranjith Kumar, R.; Mutanda, T.; Bux, F. Dual role of microalgae: Phycoremediation of domestic wastewater and biomass production for sustainable biofuels production. Appl. Energy 2011, 88, 3411-3424. [CrossRef]

71. Koutra, E.; Mastropetros, S.G.; Ali, S.S.; Tsigkou, K.; Kornaros, M. Assessing the potential of Chlorella vulgaris for valorization of liquid digestates from agro-industrial and municipal organic wastes in a biorefinery approach. J. Clean. Prod. 2021, $280,124352$. [CrossRef]

72. Ljubic, A.; Safafar, H.; Holdt, S.L.; Jacobsen, C. Biomass composition of Arthrospira platensis during cultivation on industrial process water and harvesting. J. Appl. Phycol. 2018, 30, 943-954. [CrossRef]

73. Kujawska, N.; Talbierz, S.; Dębowski, M.; Kazimierowicz, J.; Zieliński, M. Cultivation method effect on Schizochytrium sp. biomass growth and docosahexaenoic acid (DHA) production with the use of waste glycerol as a source of organic carbon. Energies 2021, 14, 2952. [CrossRef]

74. Kujawska, N.; Talbierz, S.; Dębowski, M.; Kazimierowicz, J.; Zieliński, M. Optimizing docosahexaenoic acid (DHA) production by Schizochytrium sp. grown on waste glycerol. Energies 2021, 14, 1685. [CrossRef]

75. Vargas, M.A.; Rodriguez, H.; Moreno, J.; Olivares, H.; Del Campo, J.A.; Rivas, J.; Guerrero, M.G. Biochemical composition and fatty acid content of filamentous nitrogen-fixing cyanobacteria. J. Phycol. 1998, 34, 812-817. [CrossRef]

76. Tang, D.H.; Han, W.; Li, P.L.; Miao, X.L.; Zhong, J.J. $\mathrm{CO}_{2}$ biofixation and fatty acid composition of Scenedesmus obliquus and Chlorella pyrenoidosa in response to different $\mathrm{CO}_{2}$ levels. Bioresour. Technol. 2011, 102, 3071-3076. [CrossRef] [PubMed]

77. Peng, X.L.; Meng, F.P.; Wang, Y.J.; Yi, X.Y.; Cui, H.W. Effect of $\mathrm{pH}$, temperature, and $\mathrm{CO}_{2}$ concentration on growth and lipid accumulation of Nannochloropsis sp. MASCC 11. J. Ocean. Univ. China 2020, 19, 1183-1192. [CrossRef]

78. Kareya, M.S.; Mariam, I.; Shaikh, K.M.; Nesamma, A.A.; Jutur, P.P. Photosynthetic carbon partitioning and metabolic regulation in response to very-low and high $\mathrm{CO}_{2}$ in Microchloropsis gaditana NIES 2587. Front. Plant Sci. 2020, 11, 981. [CrossRef]

79. Liang, M.H.; Jiang, J.G. Advancing oleaginous microorganisms to produce lipid via metabolic engineering technology. Prog. Lipid Res. 2013, 52, 395-408. [CrossRef]

80. Goncalves, E.C.; Wilkie, A.C.; Kirst, M.; Rathinasabapathi, B. Metabolic regulation of triacylglycerol accumulation in the green algae: Identification of potential targets for engineering to improve oil yield. Plant Biotechnol. J. 2016, 14, 1649-1660. [CrossRef]

81. Kindle, K.L.; Schnell, R.A.; Fernandez, E.; Lefebvre, P.A. Stable nuclear transformation of Chlamydomonas using the Chlamydomonas gene for nitrate reductase. J. Cell Biol. 1989, 109, 2589-2601. [CrossRef]

82. Kindle, K.L. High-frequency nuclear transformation of Chlamydomonas reinhardtii. Proc. Natl. Acad. Sci. USA 1990, 87, 1228-1232. [CrossRef] [PubMed]

83. Karas, B.J.; Diner, R.E.; Lefebvre, S.C.; McQuaid, J.; Phillips, A.P.R.; Noddings, C.M.; Brunson, J.K.; Valas, R.E.; Deerinck, T.J.; Jablanovic, J.; et al. Designer diatom episomes delivered by bacterial conjugation. Nat. Commun. 2015, 6, 7925. [CrossRef] [PubMed]

84. Kumar, S.V.; Misquitta, R.W.; Reddy, V.S.; Rao, B.J.; Rajam, M.V. Genetic transformation of the green alga Chlamydomonas reinhardtii by Agrobacterium tumefaciens. Plant Sci. 2004, 166, 731-738. [CrossRef]

85. Shimogawara, K.; Fujiwara, S.; Grossman, A.; Usuda, H. High-efficiency transformation of Chlamydomonas reinhardtii by electroporation. Genetics 1998, 148, 1821-1828. [CrossRef] [PubMed]

86. Arora, N.; Yen, H.W.; Philippidis, G.P. Harnessing the power of mutagenesis and adaptive laboratory evolution for high lipid production by oleaginous microalgae and yeasts. Sustainability 2020, 12, 5125. [CrossRef]

87. Fajardo, C.; De Donato, M.; Carrasco, R.; Martinez-Rodriguez, G.; Mancera, J.M.; Fernandez-Acero, F.J. Advances and challenges in genetic engineering of microalgae. Rev. Aquac. 2020, 12, 365-381. [CrossRef]

88. Liang, M.H.; Wang, L.; Wang, Q.M.; Zhu, J.H.; Jiang, J.G. High-value bioproducts from microalgae: Strategies and progress. Crit. Rev. Food Sci. Nutr. 2019, 59, 2423-2441. [CrossRef]

89. Fang, Y.X.; Stroukov, W.; Cathomen, T.; Mussolino, C. Chimerization enables gene synthesis and lentiviral delivery of customizable TALE-based effectors. Int. J. Mol. Sci. 2020, 21, 795. [CrossRef]

90. Barrangou, R.; Fremaux, C.; Deveau, H.; Richards, M.; Boyaval, P.; Moineau, S.; Romero, D.A.; Horvath, P. CRISPR provides acquired resistance against viruses in prokaryotes. Science 2007, 315, 1709-1712. [CrossRef]

91. Balamurugan, S.; Wang, X.; Wang, H.L.; An, C.J.; Li, H.; Li, D.W.; Yang, W.D.; Liu, J.S.; Li, H.Y. Occurrence of plastidial triacylglycerol synthesis and the potential regulatory role of AGPAT in the model diatom Phaeodactylum tricornutum. Biotechnol. Biofuels 2017, 10, 97. [CrossRef]

92. Niu, Y.F.; Wang, X.; Hu, D.X.; Balamurugan, S.; Li, D.W.; Yang, W.D.; Liu, J.S.; Li, H.Y. Molecular characterization of a glycerol-3phosphate acyltransferase reveals key features essential for triacylglycerol production in Phaeodactylum tricornutum. Biotechnol. Biofuels 2016, 9, 60. [CrossRef]

93. Niu, Y.F.; Zhang, M.H.; Li, D.W.; Yang, W.D.; Liu, J.S.; Bai, W.B.; Li, H.Y. Improvement of neutral lipid and polyunsaturated fatty acid biosynthesis by overexpressing a type 2 diacylglycerol acyltransferase in marine diatom Phaeodactylum tricornutum. Mar. Drugs 2013, 11, 4558-4569. [CrossRef] [PubMed]

94. Dinamarca, J.; Levitan, O.; Kumaraswamy, G.K.; Lun, D.S.; Falkowski, P.G. Overespresssion of a diacylglycerol acyltransferase gene in Phaeodactylum tricornutum directs carbon towards lipid biosynthesis. J. Phycol. 2017, 53, 405-414. [CrossRef] [PubMed]

95. Li, D.W.; Cen, S.Y.; Liu, Y.H.; Balamurugan, S.; Zheng, X.Y.; Alimujiang, A.; Yang, W.D.; Liu, J.S.; Li, H.Y. A type 2 diacylglycerol acyltransferase accelerates the triacylglycerol biosynthesis in heterokont oleaginous microalga Nannochloropsis oceanica. J. Biotechnol. 2016, 229, 65-71. [CrossRef] [PubMed] 
96. Wei, H.H.; Shi, Y.; Ma, X.N.; Pan, Y.F.; Hu, H.H.; Li, Y.T.; Luo, M.; Gerken, H.; Liu, J. A type-I diacylglycerol acyltransferase modulates triacylglycerol biosynthesis and fatty acid composition in the oleaginous microalga, Nannochloropsis oceanica. Biotechnol. Biofuels 2017, 10, 174. [CrossRef]

97. La Russa, M.; Bogen, C.; Uhmeyer, A.; Doebbe, A.; Filippone, E.; Kruse, O.; Mussgnug, J.H. Functional analysis of three type-2 DGAT homologue genes for triacylglycerol production in the green microalga Chlamydomonas reinhardtii. J. Biotechnol. 2012, 162, 13-20. [CrossRef] [PubMed]

98. Iwai, M.; Ikeda, K.; Shimojima, M.; Ohta, H. Enhancement of extraplastidic oil synthesis in Chlamydomonas reinhardtii using a type-2 diacylglycerol acyltransferase with a phosphorus starvation-inducible promoter. Plant Biotechnol. J. 2014, 12, 808-819. [CrossRef]

99. Zou, L.G.; Chen, J.W.; Zheng, D.L.; Balamurugan, S.; Li, D.W.; Yang, W.D.; Liu, J.S.; Li, H.Y. High-efficiency promoter-driven coordinated regulation of multiple metabolic nodes elevates lipid accumulation in the model microalga Phaeodactylum tricornutum. Microb. Cell Factories 2018, 17, 54. [CrossRef] [PubMed]

100. Muto, M.; Tanaka, M.; Liang, Y.; Yoshino, T.; Matsumoto, M.; Tanaka, T. Enhancement of glycerol metabolism in the oleaginous marine diatom Fistulifera solaris JPCC DA0580 to improve triacylglycerol productivity. Biotechnol. Biofuels 2015, 8, 4. [CrossRef]

101. Yao, Y.; Lu, Y.; Peng, K.T.; Huang, T.; Niu, Y.F.; Xie, W.H.; Yang, W.D.; Liu, J.S.; Li, H.Y. Glycerol and neutral lipid production in the oleaginous marine diatom Phaeodactylum tricornutum promoted by overexpression of glycerol-3-phosphate dehydrogenase. Biotechnol. Biofuels 2014, 7, 110. [CrossRef]

102. Yamaoka, Y.; Achard, D.; Jang, S.; Legéret, B.; Kamisuki, S.; Ko, D.; Schulz-Raffelt, M.; Kim, Y.; Song, W.Y.; Nishida, I.; et al. Identification of a Chlamydomonas plastidial 2-lysophosphatidic acid acyltransferase and its use to engineer microalgae with increased oil content. Plant Biotechnol. J. 2016, 14, 2158-2167. [CrossRef]

103. Gong, Y.M.; Guo, X.J.; Wan, X.; Liang, Z.; Jiang, M. Characterization of a novel thioesterase (PtTE) from Phaeodactylum tricornutum. J. Basic Microbiol. 2011, 51, 666-672. [CrossRef] [PubMed]

104. Lei, A.P.; Chen, H.; Shen, G.M.; Hu, Z.L.; Chen, L.; Wang, J.X. Expression of fatty acid synthesis genes and fatty acid accumulation in Haematococcus pluvialis under different stressors. Biotechnol. Biofuels 2012, 5, 18. [CrossRef]

105. Xue, J.; Niu, Y.F.; Huang, T.; Yang, W.D.; Liu, J.S.; Li, H.Y. Genetic improvement of the microalga Phaeodactylum tricornutum for boosting neutral lipid accumulation. Metab. Eng. 2015, 27, 1-9. [CrossRef] [PubMed]

106. Chen, J.W.; Liu, W.J.; Hu, D.X.; Wang, X.; Balamurugan, S.; Alimujiang, A.; Yang, W.D.; Liu, J.S.; Li, H.Y. Identification of a malonyl CoA-acyl carrier protein transacylase and its regulatory role in fatty acid biosynthesis in oleaginous microalga Nannochloropsis oceanica. Biotechnol. Appl. Biochem. 2017, 64, 620-626. [CrossRef]

107. Li, Z.P.; Meng, T.; Ling, X.P.; Li, J.; Zheng, C.Q.; Shi, Y.Y.; Chen, Z.Y.; Li, Z.Q.; Li, Q.B.; Lu, Y.H.; et al. Overexpression of malonyl-CoA: ACP transacylase in Schizochytrium sp. to improve polyunsaturated fatty acid production. J. Agric. Food Chem. 2018, 66, 5382-5391. [CrossRef] [PubMed]

108. Cook, O.; Hildebrand, M. Enhancing LC-PUFA production in Thalassiosira pseudonana by overexpressing the endogenous fatty acid elongase genes. J. Appl. Phycol. 2016, 28, 897-905. [CrossRef]

109. Peng, K.T.; Zheng, C.N.; Xue, J.; Chen, X.Y.; Yang, W.D.; Liu, J.S.; Bai, W.B.; Li, H.Y. Delta 5 fatty acid desaturase upregulates the synthesis of polyunsaturated fatty acids in the marine diatom Phaeodactylum tricornutum. J. Agric. Food Chem. 2014, 62, 8773-8776. [CrossRef]

110. Kaye, Y.; Grundman, O.; Leu, S.; Zarka, A.; Zorin, B.; Didi-Cohen, S.; Khozin-Goldberg, I.; Boussiba, S. Metabolic engineering toward enhanced LC-PUFA biosynthesis in Nannochloropsis oceanica: Overexpression of endogenous Delta 12 desaturase driven by stress-inducible promoter leads to enhanced deposition of polyunsaturated fatty acids in TAG. Algal Res. Biomass Biofuels Bioprod. 2015, 11, 387-398. [CrossRef]

111. Kang, N.K.; Jeon, S.; Kwon, S.; Koh, H.G.; Shin, S.E.; Lee, B.; Choi, G.G.; Yang, J.W.; Jeong, B.R.; Chang, Y.K. Effects of overexpression of a bHLH transcription factor on biomass and lipid production in Nannochloropsis salina. Biotechnol. Biofuels 2015, 8, 200. [CrossRef] [PubMed]

112. Ibanez-Salazar, A.; Rosales-Mendoza, S.; Rocha-Uribe, A.; Ramirez-Alonso, J.I.; Lara-Hernandez, I.; Hernandez-Torres, A.; Paz-Maldonado, L.M.T.; Silva-Ramirez, A.S.; Banuelos-Hernandez, B.; Martinez-Salgado, J.L.; et al. Over-expression of Dof-type transcription factor increases lipid production in Chlamydomonas reinhardtii. J. Biotechnol. 2014, 184, 27-38. [CrossRef]

113. Salas-Montantes, C.J.; Gonzalez-Ortega, O.; Ochoa-Alfaro, A.E.; Camarena-Rangel, R.; Paz-Maldonado, L.M.T.; Rosales-Mendoza, S.; Rocha-Uribe, A.; Soria-Guerra, R.E. Lipid accumulation during nitrogen and sulfur starvation in Chlamydomonas reinhardtii overexpressing a transcription factor. J. Appl. Phycol. 2018, 30, 1721-1733. [CrossRef]

114. Bajhaiya, A.K.; Dean, A.P.; Zeef, L.A.H.; Webster, R.E.; Pittman, J.K. PSR1 is a global transcriptional regulator of phosphorus deficiency responses and carbon storage metabolism in Chlamydomonas reinhardtii. Plant Physiol. 2016, 170, 1216-1234. [CrossRef]

115. Ngan, C.Y.; Wong, C.H.; Choi, C.; Yoshinaga, Y.; Louie, K.; Jia, J.; Chen, C.; Bowen, B.; Cheng, H.Y.; Leonelli, L.; et al. Lineagespecific chromatin signatures reveal a regulator of lipid metabolism in microalgae. Nat. Plants 2015, 1, 107. [CrossRef]

116. Kwon, S.; Kang, N.K.; Koh, H.G.; Shin, S.E.; Lee, B.; Jeong, B.R.; Chang, Y.K. Enhancement of biomass and lipid productivity by overexpression of a bZIP transcription factor in Nannochloropsis salina. Biotechnol. Bioeng. 2018, 115, 331-340. [CrossRef]

117. Wang, X.; Wei, W.; Li, N.J.; Yuan, W.S.Q.; Ding, Y.; Yang, W.D.; Liu, J.S.; Balamurugan, S.; Li, H.Y. Heterogeneous expression of human PNPLA3 triggers algal lipid accumulation and lipid droplet enlargement. Algal Res. Biomass Biofuels Bioprod. 2018, 31, 276-281. [CrossRef] 
118. Wang, X.; Hao, T.B.; Balamurugan, S.; Yang, W.D.; Liu, J.S.; Dong, H.P.; Li, H.Y. A lipid droplet-associated protein involved in lipid droplet biogenesis and triacylglycerol accumulation in the oleaginous microalga Phaeodactylum tricornutum. Algal Res. Biomass Biofuels Bioprod. 2017, 26, 215-224. [CrossRef]

119. Dunahay, T.G.; Jarvis, E.E.; Dais, S.S.; Roessler, P.G. Manipulation of microalgal lipid production using genetic engineering. Appl. Biochem. Biotechnol. 1996, 57-58, 223-231. [CrossRef]

120. Xue, J.; Balamurugan, S.; Li, D.W.; Liu, Y.H.; Zeng, H.; Wang, L.; Yang, W.D.; Liu, J.S.; Li, H.Y. Glucose-6-phosphate dehydrogenase as a target for highly efficient fatty acid biosynthesis in microalgae by enhancing NADPH supply. Metab. Eng. 2017, 41, 212-221. [CrossRef]

121. Marechal, E.; Dolch, L. Increased Triacylglycerol Production in Microalgae. WO Patent 2017/129777 A1, 3 August 2017.

122. Li, Y.T.; Han, D.X.; Hu, G.R.; Dauvillee, D.; Sommerfeld, M.; Ball, S.; Hua, Q. Chlamydomonas starchless mutant defective in ADP-glucose pyrophosphorylase hyper-accumulates triacylglycerol. Metab. Eng. 2010, 12, 387-391. [CrossRef] [PubMed]

123. Work, V.H.; Radakovits, R.; Jinkerson, R.E.; Meuser, J.E.; Elliott, L.G.; Vinyard, D.J.; Laurens, L.M.L.; Dismukes, G.C.; Posewitz, M.C. Increased lipid accumulation in the Chlamydomonas reinhardtii sta7-10 starchless isoamylase mutant and increased carbohydrate synthesis in complemented strains. Eukaryot. Cell 2010, 9, 1251-1261. [CrossRef] [PubMed]

124. Daboussi, F.; Leduc, S.; Marechal, A.; Dubois, G.; Guyot, V.; Perez-Michaut, C.; Amato, A.; Falciatore, A.; Juillerat, A.; Beurdeley, M.; et al. Genome engineering empowers the diatom Phaeodactylum tricornutum for biotechnology. Nat. Commun. $2014,5,4831$. [CrossRef] [PubMed]

125. Zhu, B.H.; Shi, H.P.; Yang, G.P.; Lv, N.N.; Yang, M.; Pan, K.H. Silencing UDP-glucose pyrophosphorylase gene in Phaeodactylum tricornutum affects carbon allocation. New Biotechnol. 2016, 33, 237-244. [CrossRef]

126. Hildebrand, M.; Manandhar-Shrestha, K.; Abbriano, R. Effects of chrysolaminarin synthase knockdown in the diatom Thalassiosira pseudonana: Implications of reduced carbohydrate storage relative to green algae. Algal Res. Biomass Biofuels Bioprod. 2017, 23 , 66-77. [CrossRef]

127. Breuer, G.; de Jaeger, L.; Artus, V.P.G.; Martens, D.E.; Springer, J.; Draaisma, R.B.; Eggink, G.; Wijffels, R.H.; Lamers, P.P. Superior triacylglycerol (TAG) accumulation in starchless mutants of Scenedesmus obliquus: (II) evaluation of TAG yield and productivity in controlled photobioreactors. Biotechnol. Biofuels 2014, 7, 70. [CrossRef]

128. Kao, P.H.; Ng, I.S. CRISPRi mediated phosphoenolpyruvate carboxylase regulation to enhance the production of lipid in Chlamydomonas reinhardtii. Bioresour. Technol. 2017, 245, 1527-1537. [CrossRef]

129. Deng, X.D.; Cai, J.J.; Li, Y.J.; Fei, X.W. Expression and knockdown of the PEPC1 gene affect carbon flux in the biosynthesis of triacylglycerols by the green alga Chlamydomonas reinhardtii. Biotechnol. Lett. 2014, 36, 2199-2208. [CrossRef]

130. Wang, C.G.; Chen, X.; Li, H.; Wang, J.X.; Hu, Z.L. Artificial miRNA inhibition of phosphoenolpyruvate carboxylase increases fatty acid production in a green microalga Chlamydomonas reinhardtii. Biotechnol. Biofuels 2017, 10, 91. [CrossRef]

131. Yang, J.; Pan, Y.F.; Bowler, C.; Zhang, L.X.; Hu, H.H. Knockdown of phosphoenolpyruvate carboxykinase increases carbon flux to lipid synthesis in Phaeodactylum tricornutum. Algal Res. Biomass Biofuels Bioprod. 2016, 15, 50-58. [CrossRef]

132. Ma, Y.H.; Wang, X.; Niu, Y.F.; Yang, Z.K.; Zhang, M.H.; Wang, Z.M.; Yang, W.D.; Liu, J.S.; Li, H.Y. Antisense knockdown of pyruvate dehydrogenase kinase promotes the neutral lipid accumulation in the diatom Phaeodactylum tricornutum. Microb. Cell Factories 2014, 13, 100. [CrossRef] [PubMed]

133. Trentacoste, E.M.; Shrestha, R.P.; Smith, S.R.; Gle, C.; Hartmann, A.C.; Hildebrand, M.; Gerwick, W.H. Metabolic engineering of lipid catabolism increases microalgal lipid accumulation without compromising growth. Proc. Natl. Acad. Sci. USA 2013, 110, 19748-19753. [CrossRef] [PubMed]

134. Li, X.L.; Pan, Y.F.; Hu, H.H. Identification of the triacylglycerol lipase in the chloroplast envelope of the diatom Phaeodactylum tricornutum. Algal Res. Biomass Biofuels Bioprod. 2018, 33, 440-447. [CrossRef]

135. Barka, F.; Angstenberger, M.; Ahrendt, T.; Lorenzen, W.; Bode, H.B.; Buchel, C. Identification of a triacylglycerol lipase in the diatom Phaeodactylum tricornutum. Biochim. Biophys. Acta 2016, 1861, 239-248. [CrossRef] [PubMed]

136. Li, X.B.; Benning, C.; Kuo, M.H. Rapid triacylglycerol turnover in Chlamydomonas reinhardtii requires a lipase with broad substrate specificity. Eukaryot. Cell 2012, 11, 1451-1462. [CrossRef] [PubMed]

137. Kong, F.T.; Liang, Y.X.; Legeret, B.; Beyly-Adriano, A.; Blangy, S.; Haslam, R.P.; Napier, J.A.; Beisson, F.; Peltier, G.; Li-Beisson, Y. Chlamydomonas carries out fatty acid beta-oxidation in ancestral peroxisomes using a bona fide acyl-CoA oxidase. Plant J. 2017, 90, 358-371. [CrossRef] [PubMed]

138. Moellering, E.R.; Benning, C. RNA interference silencing of a major lipid droplet protein affects lipid droplet size in Chlamydomonas reinhardtii. Eukaryot. Cell 2010, 9, 97-106. [CrossRef]

139. Yoon, K.; Han, D.X.; Li, Y.T.; Sommerfeld, M.; Hu, Q. Phospholipid: Diacylglycerol acyltransferase is a multifunctional enzyme involved in membrane lipid turnover and degradation while synthesizing triacylglycerol in the unicellular green microalga Chlamydomonas reinhardtii. Plant Cell 2012, 24, 3708-3724. [CrossRef]

140. De Jaeger, L.; Springer, J.; Wolbert, E.J.H.; Martens, D.E.; Eggink, G.; Wijffels, R.H. Gene silencing of stearoyl-ACP desaturase enhances the stearic acid content in Chlamydomonas reinhardtii. Bioresour. Technol. 2017, 245, 1616-1626. [CrossRef] [PubMed]

141. Lau, C.C.; Loh, S.H.; Aziz, A.; Cha, T.S. Effects of disrupted omega-3 desaturase gene construct on fatty acid composition and expression of four fatty acid biosynthetic genes in transgenic Chlorella vulgaris. Algal Res. Biomass Biofuels Bioprod. 2017, 26, 143-152. [CrossRef] 
142. Hao, X.H.; Luo, L.; Jouhet, J.; Rebeille, F.; Marechal, E.; Hu, H.H.; Pan, Y.F.; Tan, X.M.; Chen, Z.; You, L.J.; et al. Enhanced triacylglycerol production in the diatom Phaeodactylum tricornutum by inactivation of a Hotdog-fold thioesterase gene using TALEN-based targeted mutagenesis. Biotechnol. Biofuels 2018, 11, 312. [CrossRef]

143. Shtaida, N.; Khozin-Goldberg, I.; Solovchenko, A.; Chekanov, K.; Didi-Cohen, S.; Leu, S.; Cohen, Z.; Boussiba, S. Downregulation of a putative plastid PDC E1 alpha subunit impairs photosynthetic activity and triacylglycerol accumulation in nitrogen-starved photoautotrophic Chlamydomonas reinhardtii. J. Exp. Bot. 2014, 65, 6563-6576. [CrossRef]

144. Liu, J.; Han, D.X.; Yoon, K.; Hu, Q.; Li, Y.T. Characterization of type 2 diacylglycerol acyltransferases in Chlamydomonas reinhardtii reveals their distinct substrate specificities and functions in triacylglycerol biosynthesis. Plant J. 2016, 86, 3-19. [CrossRef] [PubMed]

145. McCarthy, J.K.; Smith, S.R.; McCrow, J.P.; Tan, M.; Zheng, H.; Beeri, K.; Roth, R.; Lichtle, C.; Goodenough, U.; Bowler, C.P.; et al. Nitrate reductase knockout uncouples nitrate transport from nitrate assimilation and drives repartitioning of carbon flux in a model pennate diatom. Plant Cell 2017, 29, 2047-2070. [CrossRef] [PubMed]

146. Levitan, O.; Dinamarca, J.; Zelzion, E.; Gorbunov, M.Y.; Falkowski, P.G. An RNA interference knock-down of nitrate reductase enhances lipid biosynthesis in the diatom Phaeodactylum tricornutum. Plant J. 2015, 84, 963-973. [CrossRef] [PubMed]

147. Ajjawi, I.; Verruto, J.; Aqui, M.; Soriaga, L.B.; Coppersmith, J.; Kwok, K.; Peach, L.; Orchard, E.; Kalb, R.; Xu, W.D.; et al. Lipid production in Nannochloropsis gaditana is doubled by decreasing expression of a single transcriptional regulator. Nat. Biotechnol. 2017, 35, 647-652. [CrossRef]

148. Meireles, L.A.; Guedes, A.C.; Malcata, F.X. Increase of the yields of eicosapentaenoic and docosahexaenoic acids by the microalga Pavlova lutheri following random mutagenesis. Biotechnol. Bioeng. 2003, 81, 50-55. [CrossRef]

149. Osorio, H.; Jara, C.; Fuenzalida, K.; Rey-Jurado, E.; Vasquez, M. High-efficiency nuclear transformation of the microalgae Nannochloropsis oceanica using Tn5 Transposome for the generation of altered lipid accumulation phenotypes. Biotechnol. Biofuels 2019, 12, 134. [CrossRef] [PubMed]

150. Iskandarov, U.; Sitnik, S.; Shtaida, N.; Didi-Cohen, S.; Leu, S.; Khozin-Goldberg, I.; Cohen, Z.; Boussiba, S. Cloning and characterization of a GPAT-like gene from the microalga Lobosphaera incisa (Trebouxiophyceae): Overexpression in Chlamydomonas reinhardtii enhances TAG production. J. Appl. Phycol. 2016, 28, 907-919. [CrossRef]

151. Hamilton, M.L.; Haslam, R.P.; Napier, J.A.; Sayanova, O. Metabolic engineering of Phaeodactylum tricornutum for the enhanced accumulation of omega-3 long chain polyunsaturated fatty acids. Metab. Eng. 2014, 22, 3-9. [CrossRef]

152. Kobayashi, T.; Sakaguchi, K.; Matsuda, T.; Abe, E.; Hama, Y.; Hayashi, M.; Honda, D.; Okita, Y.; Sugimoto, S.; Okino, N.; et al. Increase of eicosapentaenoic acid in Thraustochytrids through thraustochytrid ubiquitin promoter-driven expression of a fatty acid delta 5 desaturase gene. Appl. Environ. Microbiol. 2011, 77, 3870-3876. [CrossRef]

153. Talebi, A.F.; Tohidfar, M.; Derazmahalleh, S.M.M.; Sulaiman, A.; Baharuddin, A.S.; Tabatabaei, M. Biochemical modulation of lipid pathway in microalgae Dunaliella sp. for biodiesel production. BioMed Res. Int. 2015, 2015, 597198. [CrossRef]

154. Tan, K.W.M.; Lee, Y.K. Expression of the heterologous Dunaliella tertiolecta fatty acyl-ACP thioesterase leads to increased lipid production in Chlamydomonas reinhardtii. J. Biotechnol. 2017, 247, 60-67. [CrossRef] [PubMed]

155. Chen, C.Y.; Kao, A.L.; Tsai, Z.C.; Chow, T.J.; Chang, H.Y.; Zhao, X.Q.; Chen, P.T.; Su, H.Y.; Chang, J.S. Expression of type 2 diacylglycerol acyltransferse gene DGTT1 from Chlamydomonas reinhardtii enhances lipid production in Scenedesmus obliquus. Biotechnol. J. 2016, 11, 336-344. [CrossRef]

156. Ahmad, I.; Sharma, A.K.; Daniell, H.; Kumar, S. Altered lipid composition and enhanced lipid production in green microalga by introduction of brassica diacylglycerol acyltransferase 2. Plant Biotechnol. J. 2015, 13, 540-550. [CrossRef] [PubMed]

157. Zulu, N.N.; Popko, J.; Zienkiewicz, K.; Tarazona, P.; Herrfurth, C.; Feussner, I. Heterologous co-expression of a yeast diacylglycerol acyltransferase (ScDGA1) and a plant oleosin (AtOLEO3) as an efficient tool for enhancing triacylglycerol accumulation in the marine diatom Phaeodactylum tricornutum. Biotechnol. Biofuels 2017, 10, 187. [CrossRef]

158. Hsieh, H.J.; Su, C.H.; Chien, L.J. Accumulation of lipid production in Chlorella minutissima by triacylglycerol biosynthesis-related genes cloned from Saccharomyces cerevisiae and Yarrowia lipolytica. J. Microbiol. 2012, 50, 526-534. [CrossRef]

159. Ren, L.J.; Zhuang, X.Y.; Chen, S.L.; Ji, X.J.; Huang, H. Introduction of omega-3 desaturase obviously changed the fatty acid profile and sterol content of Schizochytrium sp. J. Agric. Food Chem. 2015, 63, 9770-9776. [CrossRef] [PubMed]

160. Sumiya, N.; Kawase, Y.; Hayakawa, J.; Matsuda, M.; Nakamura, M.; Era, A.; Tanaka, K.; Kondo, A.; Hasunuma, T.; Imamura, S.; et al. Expression of cyanobacterial Acyl-ACP reductase elevates the triacylglycerol level in the red alga Cyanidioschyzon merolae. Plant Cell Physiol. 2015, 56, 1962-1980. [CrossRef]

161. Radakovits, R.; Eduafo, P.M.; Posewitz, M.C. Genetic engineering of fatty acid chain length in Phaeodactylum tricornutum. Metab. Eng. 2011, 13, 89-95. [CrossRef]

162. Lin, H.X.; Lee, Y.K. Genetic engineering of medium-chain-length fatty acid synthesis in Dunaliella tertiolecta for improved biodiesel production. J. Appl. Phycol. 2017, 29, 2811-2819. [CrossRef]

163. Inaba, Y.; Nakahigashi, K.; Ito, T.; Tomita, M. Alteration of fatty acid chain length of Chlamydomonas reinhardtii by simultaneous expression of medium-chain-specific thioesterase and acyl carrier protein. Phycol. Res. 2017, 65, 94-99. [CrossRef]

164. Gomma, A.E.; Lee, S.K.; Sun, S.M.; Yang, S.H.; Chung, G. Improvement in oil production by increasing malonyl-CoA and glycerol-3-phosphate pools in Scenedesmus quadricauda. Indian J. Microbiol. 2015, 55, 447-455. [CrossRef] [PubMed]

165. Yan, J.F.; Cheng, R.B.; Lin, X.Z.; You, S.; Li, K.; Rong, H.; Ma, Y. Overexpression of acetyl-CoA synthetase increased the biomass and fatty acid proportion in microalga Schizochytrium. Appl. Microbiol. Biotechnol. 2013, 97, 1933-1939. [CrossRef] 
166. Pudney, A.; Gandini, C.; Economou, C.K.; Smith, R.; Goddard, P.; Napier, J.A.; Spicer, A.; Sayanova, O. Multifunctionalizing the marine diatom Phaeodactylum tricornutum for sustainable co-production of omega-3 long chain polyunsaturated fatty acids and recombinant phytase. Sci. Rep. 2019, 9, 11444. [CrossRef]

167. Zhang, J.H.; Hao, Q.; Bai, L.L.; Xu, J.; Yin, W.B.; Song, L.Y.; Xu, L.; Guo, X.J.; Fan, C.M.; Chen, Y.H.; et al. Overexpression of the soybean transcription factor GmDof4 significantly enhances the lipid content of Chlorella ellipsoidea. Biotechnol. Biofuels 2014, 7, 128. [CrossRef] [PubMed]

168. Kang, N.K.; Kim, E.K.; Kim, Y.U.; Lee, B.; Jeong, W.J.; Jeong, B.R.; Chang, Y.K. Increased lipid production by heterologous expression of AtWRI1 transcription factor in Nannochloropsis salina. Biotechnol. Biofuels 2017, 10, 231. [CrossRef]

169. Hou, L.; Jia, X.; Shi, D.; Wang, X. Expression of PEPC gene, lipid content and photosynthesis in Anabaena 7120. In Photosynthesis Research for Food, Fuel and the Future; Advanced topics in science and technology in China; Springer: Berlin/Heidelberg, Germany, 2008; pp. 335-338.

170. Xie, W.H.; Pang, F.; Niu, Y.F.; Zhang, M.H.; Yang, W.D.; Liu, J.S.; Yan, D.G.; Li, H.Y. Functional characterization of an ACCase subunit from the diatom Phaeodactylum tricornutum expressed in Escherichia coli. Biotechnol. Appl. Biochem. 2013, 60, 330-335. [CrossRef] [PubMed]

171. Qi, B.X.; Fraser, T.; Mugford, S.; Dobson, G.; Sayanova, O.; Butler, J.; Napier, J.A.; Stobart, A.K.; Lazarus, C.M. Production of very long chain polyunsaturated omega-3 and omega-6 fatty acids in plants. Nat. Biotechnol. 2004, 22, 739-745. [CrossRef]

172. Xia, F.; Li, X.Y.; Li, X.Z.; Zheng, D.S.; Sun, Q.X.; Liu, J.; Li, Y.X.; Hua, J.P.; Qi, B.X. Elevation of the yields of very long chain polyunsaturated fatty acids via minimal codon optimization of two key biosynthetic enzymes. PLoS ONE 2016, 11. [CrossRef]

173. Petrie, J.R.; Shrestha, P.; Mansour, M.P.; Nichols, P.D.; Liu, Q.; Singh, S.P. Metabolic engineering of omega-3 long-chain polyunsaturated fatty acids in plants using an acyl-CoA Delta 6-desaturase with omega 3-preference from the marine microalga Micromonas pusilla. Metab. Eng. 2010, 12, 233-240. [CrossRef]

174. Abbadi, A.; Domergue, F.; Bauer, J.; Napier, J.A.; Welti, R.; Zahringer, U.; Cirpus, P.; Heinz, E. Biosynthesis of very-long-chain polyunsaturated fatty acids in transgenic oilseeds: Constraints on their accumulation. Plant Cell 2004, 16, 2734-2748. [CrossRef]

175. Walsh, T.A.; Bevan, S.A.; Gachotte, D.J.; Larsen, C.M.; Moskal, W.A.; Merlo, P.A.O.; Sidorenko, L.V.; Hampton, R.E.; Stoltz, V.; Pareddy, D.; et al. Canola engineered with a microalgal polyketide synthase-like system produces oil enriched in docosahexaenoic acid. Nat. Biotechnol. 2016, 34, 881-887. [CrossRef] [PubMed]

176. Jiang, M.L.; Guo, B.; Wan, X.; Gong, Y.M.; Zhang, Y.B.; Hu, C.J. Isolation and characterization of the diatom Phaeodactylum delta 5-elongase gene for transgenic LC-PUFA production in Pichia pastoris. Mar. Drugs 2014, 12, 1317-1334. [CrossRef] [PubMed]

177. Lu, Y.D.; Chi, X.Y.; Yang, Q.L.; Li, Z.X.; Liu, S.F.; Gan, Q.H.; Qin, S. Molecular cloning and stress-dependent expression of a gene encoding Delta(12)-fatty acid desaturase in the Antarctic microalga Chlorella vulgaris NJ-7. Extremophiles 2009, 13, 875-884. [CrossRef] [PubMed]

178. Hung, C.H.; Ho, M.Y.; Kanehara, K.; Nakamura, Y. Functional study of diacylglycerol acyltransferase type 2 family in Chlamydomonas reinhardtii. FEBS Lett. 2013, 587, 2364-2370. [CrossRef] [PubMed]

179. Domergue, F.; Lerchl, J.; Zahringer, U.; Heinz, E. Cloning and functional characterization of Phaeodactylum tricornutum front-end desaturases involved in eicosapentaenoic acid biosynthesis. Eur. J. Biochem. 2002, 269, 4105-4113. [CrossRef] [PubMed]

180. Shi, H.S.; Chen, H.Q.; Gu, Z.N.; Zhang, H.; Chen, W.; Chen, Y.Q. Application of a delta-6 desaturase with alpha-linolenic acid preference on eicosapentaenoic acid production in Mortierella alpina. Microb. Cell Factories 2016, 15, 117. [CrossRef]

181. Thiyagarajan, S.; Arumugam, M.; Senthil, N.; Vellaikumar, S.; Kathiresan, S. Functional characterization and substrate specificity analysis of Delta 6-desaturase from marine microalga Isochrysis sp. Biotechnol. Lett. 2018, 40, 577-584. [CrossRef]

182. Thiyagarajan, S.; Arumugam, M.; Kathiresan, S. Identification and functional characterization of two novel fatty acid genes from marine microalgae for eicosapentaenoic acid production. Appl. Biochem. Biotechnol. 2020, 190, 1371-1384. [CrossRef]

183. Li-Beisson, Y.; Thelen, J.J.; Fedosejevs, E.; Harwood, J.L. The lipid biochemistry of eukaryotic algae. Prog. Lipid Res. 2019, 74, 31-68. [CrossRef]

184. Davis, D.; Rudenko, G.; Somanchi, A.; Casolari, J.; Franklin, S.; Ewing, A. Novel Ketoacyl ACP Synthase Genes and Uses Thereof. U.S. Patent 2019/0345463 A1, 14 January 2016.

185. Ozaki, T. Lipid Production Method Using Acyl-ACP Thioesterase. JP Patent 2016007154 A, 18 January 2016.

186. Moreno-Sanchez, R.; Saavedra, E.; Rodriguez-Enriquez, S.; Olin-Sandoval, V. Metabolic control analysis: A tool for designing strategies to manipulate metabolic pathways. J. Biomed. Biotechnol. 2008, 2008, 597913. [CrossRef]

187. Fell, D.A. Understanding the Control of Metabolism; Portland Press: London, UK, 2007; 306p.

188. Sayanova, O.; Mimouni, V.; Ulmann, L.; Morant-Manceau, A.; Pasquet, V.; Schoefs, B.; Napier, J.A. Modulation of lipid biosynthesis by stress in diatoms. Philos. Trans. R. Soc. B Biol. Sci. 2017, 372, 407. [CrossRef] [PubMed]

189. Krogdahl, A.; Penn, M.; Thorsen, J.; Refstie, S.; Bakke, A.M. Important antinutrients in plant feedstuffs for aquaculture: An update on recent findings regarding responses in salmonids. Aquac. Res. 2010, 41, 333-344. [CrossRef]

190. Fan, J.L.; Andre, C.; Xu, C.C. A chloroplast pathway for the de novo biosynthesis of triacylglycerol in Chlamydomonas reinhardtii. FEBS Lett. 2011, 585, 1985-1991. [CrossRef] [PubMed]

191. Kim, H.U.; Huang, A.H.C. Plastid lysophosphatidyl acyltransferase is essential for embryo development in Arabidopsis. Plant Physiol. 2004, 134, 1206-1216. [CrossRef]

192. Kim, H.U.; Lee, K.R.; Jung, S.J.; Shin, H.A.; Go, Y.S.; Suh, M.C.; Kim, J.B. Senescence-inducible LEC2 enhances triacylglycerol accumulation in leaves without negatively affecting plant growth. Plant Biotechnol. J. 2015, 13, 1346-1359. [CrossRef] 
193. Jiang, P.; Yang, G.; Jin, Z.; Huaxin, C. Method for Increasing Lipid Content of Diatom Through Metabolism Gene Engineering. CN Patent 105219649 A, 6 January 2016.

194. Yi, X.; Xy, J. Gene with Triglyceride (TAG) Synthesis Function and Construction Method and Application Thereof. CN Patent 110305883 A, 8 October 2019.

195. Chen, W.; Zhou, P.P.; Zhu, Y.M.; Xie, C.; Ma, L.; Wang, X.P.; Bao, Z.D.; Yu, L.J. Improvement in the docosahexaenoic acid production of Schizochytrium sp. S056 by replacement of sea salt. Bioprocess Biosyst. Eng. 2016, 39, 315-321. [CrossRef] [PubMed]

196. Hu, Z.; Fan, C.; Chen, Y. Chlorella ellipsoidea NF-YC Gene and Application Thereof. CN Patent 108101973 A, 1 July 2018.

197. Li, Y.T.; Han, D.X.; Hu, G.R.; Sommerfeld, M.; Hu, Q.A. Inhibition of starch synthesis results in overproduction of lipids in Chlamydomonas reinhardtii. Biotechnol. Bioeng. 2010, 107, 258-268. [CrossRef]

198. Deng, W.; Cai, J.X.; Zhang, J.Y.; Chen, Y.Y.; Chen, Y.R.; Di, Y.J.; Yuan, S.Z. Molecular basis of resistance to ACCase-inhibiting herbicide cyhalofop-butyl in Chinese sprangletop (Leptochloa chinensis (L.) Nees) from China. Pestic. Biochem. Physiol. 2019, 158, 143-148. [CrossRef]

199. Cygler, M.; Schrag, J.D. Structure as basis for understanding interfacial properties of lipases. Methods Enzymol. 1997, $284,3-27$.

200. Sayanova, O.; Napier, J.A. Metabolic engineering of microalgae for sustainable production of omega-3 long chain polyunsaturated fatty acids. Curr. Biotechnol. 2016, 5, 198-212. [CrossRef]

201. Yang, Y.X.; Ahammed, G.J.; Wan, C.P.; Liu, H.J.; Chen, R.R.; Zhou, Y. Comprehensive analysis of TIFY transcription factors and their expression profiles under jasmonic acid and abiotic stresses in watermelon. Int. J. Genom. 2019, 2019, 6813086. [CrossRef]

202. Liu, A.F.; Yu, X.Y.; Liu, S.R. Pluripotency transcription factors and cancer stem cells: Small genes make a big difference. Chin. J. Cancer 2013, 32, 483-487. [CrossRef] [PubMed]

203. Liang, Z.C.; Liang, M.H.; Jiang, J.G. Transgenic microalgae as bioreactors. Crit. Rev. Food Sci. Nutr. 2020, 60, 3195-3213. [CrossRef]

204. Bajhaiya, A.K.; Moreira, J.Z.; Pittman, J.K. Transcriptional engineering of microalgae: Prospects for high-value chemicals. Trends Biotechnol. 2017, 35, 95-99. [CrossRef]

205. Hu, Z.; Fan, C.; Sun, P.; Chen, Y. Chlorella ellipsoidea NF-YA Gene and Application Thereof. CN Patent 107936098 A, 20 April 2018

206. Hu, Z.; Fan, C.; Chen, Y. Chlorella ellipsoidea NF-YB Gene and Application Thereof. CN Patent 108003226 A, 8 May 2018.

207. Yang, J.W.; Kang, N.K.; Jeong, B.R.; Park, M.S.; Lee, B.S.; Choi, G.G.; Jeon, S.J.; Kwon, S.H. Recombinant Vector for Increasing Biomass and Lipid Productivity of Microalgae and Use Thereof. WO Patent 2015/105233 A1, 16 July 2015.

208. Li, J.W.; Zhang, X.Y.; Wu, H.; Bai, Y.P. Transcription factor engineering for high-throughput strain evolution and organic acid bioproduction: A review. Front. Bioeng. Biotechnol. 2020, 8, 98. [CrossRef] [PubMed]

209. Tibbetts, S.M.; Scaife, M.A.; Armenta, R.E. Apparent digestibility of proximate nutrients, energy and fatty acids in nutritionallybalanced diets with partial or complete replacement of dietary fish oil with microbial oil from a novel Schizochytrium sp. (T18) by juvenile Atlantic salmon (Salmo salar L.). Aquaculture 2020, 520, 735003. [CrossRef]

210. Cornelio, F.H.G.; da Cunha, D.A.; Silveira, J.; Alexandre, D.; Silva, C.P.; Fracalossi, D.M. Dietary protein requirement of juvenile cachara catfish, Pseudoplatystoma reticulatum. J. World Aquac. Soc. 2014, 45, 45-54. [CrossRef]

211. Sarker, P.K.; Kapuscinski, A.R.; McKuin, B.; Fitzgerald, D.S.; Nash, H.M.; Greenwood, C. Microalgae-blend tilapia feed eliminates fishmeal and fish oil, improves growth, and is cost viable. Sci. Rep. 2020, 10, 19328. [CrossRef] [PubMed]

212. Maldonado-Othon, C.A.; Perez-Velazquez, M.; Gatlin, D.M.; Gonzalez-Felix, M.L. Replacement of of fish oil by soybean oil and microalgal meals in diets for Totoaba macdonaldi (Gilbert, 1890) juveniles. Aquaculture 2020, 529, 735705. [CrossRef]

213. Olsen, R.L.; Hasan, M.R. A limited supply of fishmeal: Impact on future increases in global aquaculture production. Trends Food Sci. Technol. 2012, 27, 120-128. [CrossRef]

214. Beal, C.M.; Gerber, L.N.; Thongrod, S.; Phromkunthong, W.; Kiron, V.; Granados, J.; Archibald, I.; Greene, C.H.; Huntley, M.E. Marine microalgae commercial production improves sustainability of global fisheries and aquaculture. Sci. Rep. 2018, 8, 15064. [CrossRef] [PubMed]

215. Sørensen, M.; Berge, G.M.; Reitan, K.I.; Ruyter, B. Microalga Phaeodactylum tricornutum in feed for Atlantic salmon (Salmo salar)—Effect on nutrient digestibility, growth and utilization of feed. Aquaculture 2016, 460, 116-123. [CrossRef]

216. Gonzalez-Fernandez, C.; Munoz, R. (Eds.) Microalgae-Based Biofuels and Bioproducts: From Feedstock Cultivation to End-Products; Elsevier: Amsterdam, The Netherlands, 2017; 540p.

217. De la Fuente-Vazquez, J.; Diaz-Diaz-Chiron, M.T.; Perez-Marcos, C.; Caneque-Martinez, V.; Sanchez-Gonzalez, C.I.; Alvarez-Acero, I.; Fernandez-Bermejo, C.; Rivas-Canedo, A.; Lauzurica-Gomez, S. Linseed, microalgae or fish oil dietary supplementation affects performance and quality characteristics of light lambs. Span. J. Agric. Res. 2014, 12, 436-447. [CrossRef]

218. Barron, J.M.; Twibell, R.G.; Hill, H.A.; Hanson, K.C.; Gannam, A.L. Development of diets for the intensive culture of Pacific lamprey. Aquac. Res. 2016, 47, 3899-3906. [CrossRef]

219. Miller, M.R.; Nichols, P.D.; Carter, C.G. Replacement of fish oil with thraustochytrid Schizochytrium sp. L. oil in Atlantic salmon parr (Salmo salar L.) diets. Comp. Biochem. Physiol. A-Mol. Integr. Physiol. 2007, 148, 382-392. [CrossRef] [PubMed]

220. Sarker, P.K.; Kapuscinski, A.R.; Lanois, A.J.; Livesey, E.D.; Bernhard, K.P.; Coley, M.L. Towards sustainable aquafeeds: Complete substitution of fish oil with marine microalga Schizochytrium sp. improves growth and fatty acid deposition in juvenile Nile tilapia (Oreochromis niloticus). PLoS ONE 2016, 11. [CrossRef] 
221. Cortegano, C.A.A.; de Alcantara, A.M.; da Silva, A.F.; Epifanio, C.M.F.; Bentes, S.P.C.; dos Santos, V.J.; Visentainer, J.V.; Goncalves, L.U. Finishing plant diet supplemented with microalgae meal increases the docosahexaenoic acid content in Colossoma macropomum flesh. Aquac. Res. 2019, 50, 1291-1299. [CrossRef]

222. Belanger, A.; Sarker, P.K.; Bureau, D.P.; Chouinard, Y.; Vandenberg, G.W. Apparent digestibility of macronutrients and fatty acids from microalgae (Schizochytrium sp.) fed to rainbow trout (Oncorhynchus mykiss): A potential candidate for fish oil substitution. Animals 2021, 11, 456. [CrossRef]

223. Seong, T.; Matsutani, H.; Haga, Y.; Kitagima, R.; Satoh, S. First step of non-fish meal, non-fish oil diet development for red seabream, (Pagrus major), with plant protein sources and microalgae Schizochytrium sp. Aquac. Res. 2019, 50, 2460-2468. [CrossRef]

224. Yan, L.; Kim, I.H. Effects of dietary omega-3 fatty acid-enriched microalgae supplementation on growth performance, blood profiles, meat quality, and fatty acid composition of meat in broilers. J. Appl. Anim. Res. 2013, 41, 392-397. [CrossRef]

225. Li, M.H.H.; Robinson, E.H.; Tucker, C.S.; Manning, B.B.; Khoo, L. Effects of dried algae Schizochytrium sp., a rich source of docosahexaenoic acid, on growth, fatty acid composition, and sensory quality of channel catfish Ictalurus punctatus. Aquaculture 2009, 292, 232-236. [CrossRef]

226. Kumar, V.; Habte-Tsion, H.M.; Allen, K.M.; Bowman, B.A.; Thompson, K.R.; El-Haroun, E.; Filer, K.; Tidwell, J.H. Replacement of fish oil with Schizochytrium meal and its impacts on the growth and lipid metabolism of Pacific white shrimp (Litopenaeus vannamei). Aquac. Nutr. 2018, 24, 1769-1781. [CrossRef]

227. Urrutia, O.; Mendizabal, J.A.; Insausti, K.; Soret, B.; Purroy, A.; Arana, A. Effects of addition of linseed and marine algae to the diet on adipose tissue development, fatty acid profile, lipogenic gene expression, and meat quality in lambs. PLoS ONE 2016, 11. [CrossRef]

228. Mordenti, A.L.; Sardi, L.; Bonaldo, A.; Pizzamiglio, V.; Brogna, N.; Cipollini, I.; Tassinari, M.; Zaghini, G. Influence of marine algae (Schizochytrium spp.) dietary supplementation on doe performance and progeny meat quality. Livest. Sci. 2010, 128, 179-184. [CrossRef]

229. Kousoulaki, K.; Morkore, T.; Nengas, I.; Berge, R.K.; Sweetman, J. Microalgae and organic minerals enhance lipid retention efficiency and fillet quality in Atlantic salmon (Salmo salar L.). Aquaculture 2016, 451, 47-57. [CrossRef]

230. Garcia-Ortega, A.; Kissinger, K.R.; Trushenski, J.T. Evaluation of fish meal and fish oil replacement by soybean protein and algal meal from Schizochytrium limacinum in diets for giant grouper Epinephelus lanceolatus. Aquaculture 2016, 452, 1-8. [CrossRef]

231. Bouras, S.; Katsoulas, N.; Antoniadis, D.; Karapanagiotidis, I.T. Use of biofuel industry wastes as alternative nutrient sources for DHA-Yielding Schizochytrium limacinum production. Appl. Sci. 2020, 10, 4398. [CrossRef]

232. Jaseera, K.V.; Ebeneezar, S.; Sayooj, P.; Nair, A.V.; Kaladharan, P. Dietary supplementation of microalgae, Aurantiochytrium sp. and co-feeding with Artemia enhances the growth, stress tolerance and survival in Penaeus monodon (Fabricius, 1798) post larvae. Aquaculture 2021, 533, 736176. [CrossRef]

233. Tibaldi, E.; Zittelli, G.C.; Parisi, G.; Bruno, M.; Giorgi, G.; Tulli, F.; Venturini, S.; Tredici, M.R.; Poli, B.M. Growth performance and quality traits of European sea bass (D. labrax) fed diets including increasing levels of freeze-dried Isochrysis sp. (T-ISO) biomass as a source of protein and n-3 long chain PUFA in partial substitution of fish derivatives. Aquaculture 2015, 440, 60-68. [CrossRef]

234. He, Y.J.; Lin, G.; Rao, X.Z.; Chen, L.J.; Jian, H.; Wang, M.Z.; Guo, Z.; Chen, B.L. Microalga Isochrysis galbana in feed for Trachinotus ovatus: Effect on growth performance and fatty acid composition of fish fillet and liver. Aquac. Int. 2018, 26, 1261-1280. [CrossRef]

235. Atalah, E.; Cruz, C.M.H.; Izquierdo, M.S.; Rosenlund, G.; Caballero, M.J.; Valencia, A.; Robaina, L. Two microalgae Crypthecodinium cohnii and Phaeodactylum tricornutum as alternative source of essential fatty acids in starter feeds for seabream (Sparus aurata). Aquaculture 2007, 270, 178-185. [CrossRef]

236. Sheikhzadeh, N.; Tayefi-Nasrabadi, H.; Oushani, A.K.; Enferadi, M.H.N. Effects of Haematococcus pluvialis supplementation on antioxidant system and metabolism in rainbow trout (Oncorhynchus mykiss). Fish Physiol. Biochem. 2012, 38, 413-419. [CrossRef] [PubMed]

237. Austic, R.E.; Mustafa, A.; Jung, B.; Gatrell, S.; Lei, X.G. Potential and limitation of a new defatted diatom microalgal biomass in replacing soybean meal and corn in diets for broiler chickens. J. Agric. Food Chem. 2013, 61, 7341-7348. [CrossRef]

238. Velasquez, S.F.; Chan, M.A.; Abisado, R.G.; Traifalgar, R.F.M.; Tayamen, M.M.; Maliwat, G.C.F.; Ragaza, J.A. Dietary Spirulina (Arthrospira platensis) replacement enhances performance of juvenile Nile tilapia (Oreochromis niloticus). J. Appl. Phycol. 2016, 28, 1023-1030. [CrossRef]

239. Bonos, E.; Kasapidou, E.; Kargopoulos, A.; Karampampas, A.; Christaki, E.; Florou-Paneri, P.; Nikolakakis, I. Spirulina as a functional ingredient in broiler chicken diets. S. Afr. J. Anim. Sci. 2016, 46, 94-102. [CrossRef]

240. Raji, A.A.; Alaba, P.A.; Yusuf, H.; Abu Bakar, N.H.; Taufek, N.M.; Muin, H.; Alias, Z.; Milow, P.; Razak, S.A. Fishmeal replacement with Spirulina Platensis and Chlorella vulgaris in African catfish (Clarias gariepinus) diet: Effect on antioxidant enzyme activities and haematological parameters. Res. Vet. Sci. 2018, 119, 67-75. [CrossRef] [PubMed]

241. Shi, X.; Luo, Z.; Chen, F.; Wei, C.C.; Wu, K.; Zhu, X.M.; Liu, X. Effect of fish meal replacement by Chlorella meal with dietary cellulase addition on growth performance, digestive enzymatic activities, histology and myogenic genes' expression for crucian carp Carassius auratus. Aquac. Res. 2017, 48, 3244-3256. [CrossRef]

242. Kupchinsky, Z.A.; Coyle, S.D.; Bright, L.A.; Tidwell, J.H. Evaluation of heterotrophic algae meal as a diet ingredient for channel catfish, Ictalurus punctatus. J. World Aquac. Soc. 2015, 46, 445-452. [CrossRef] 
243. Castro, C.; Coutinho, F.; Iglesias, P.; Oliva-Teles, A.; Couto, A. Chlorella sp. and Nannochloropsis sp. inclusion in plant-based diets modulate the intestine and liver antioxidant mechanisms of European sea bass juveniles. Front. Vet. Sci. 2020, 7, 607575. [CrossRef]

244. Teuling, E.; Wierenga, P.A.; Agboola, J.O.; Gruppen, H.; Schrama, J.W. Cell wall disruption increases bioavailability of Nannochloropsis gaditana nutrients for juvenile Nile tilapia (Oreochromis niloticus). Aquaculture 2019, 499, 269-282. [CrossRef]

245. Sales, R.; Galafat, A.; Vizcaino, A.J.; Saez, M.I.; Martinez, T.F.; Ceron-Garcia, M.C.; Navarro-Lopez, E.; Tsuzuki, M.Y.; AcienFernandez, F.G.; Molina-Grima, E.; et al. Effects of dietary use of two lipid extracts from the microalga Nannochloropsis gaditana (Lubian, 1982) alone and in combination on growth and muscle composition in juvenile gilthead seabream, Sparus aurata. Algal Res. Biomass Biofuels Bioprod. 2021, 53, 102162. [CrossRef]

246. Oswald, A.T.O.; Ishikawa, M.; Koshio, S.; Yokoyama, S.; Moss, A.S.; Serge, D. Nutritional evaluation of Nannochloropsis powder and lipid as alternative to fish oil for kuruma shrimp, Marsupenaeus japonicus. Aquaculture 2019, 504, 427-436. [CrossRef]

247. Valente, L.M.P.; Custodio, M.; Batista, S.; Fernandes, H.; Kiron, V. Defatted microalgae (Nannochloropsis sp.) from biorefinery as a potential feed protein source to replace fishmeal in European sea bass diets. Fish Physiol. Biochem. 2019, 45, 1067-1081. [CrossRef]

248. Gbadamosi, O.K.; Lupatsch, I. Effects of dietary Nannochloropsis salina on the nutritional performance and fatty acid profile of Nile tilapia, Oreochromis niloticus. Algal Res. Biomass Biofuels Bioprod. 2018, 33, 48-54. [CrossRef]

249. Haas, S.; Bauer, J.L.; Adakli, A.; Meyer, S.; Lippemeier, S.; Schwarz, K.; Schulz, C. Marine microalgae Pavlova viridis and Nannochloropsis sp. as n-3 PUFA source in diets for juvenile European sea bass (Dicentrarchus labrax L.). J. Appl. Phycol. 2016, 28, 1011-1021. [CrossRef]

250. Ponis, E.; Parisi, G.; Le Coz, J.R.; Robert, R.; Zittelli, G.C.; Tredici, R. Effect of the culture system and culture technique on biochemical characteristics of Pavlova lutheri and its nutritional value for Crassostrea gigas larvae. Aquac. Nutr. 2006, 12, 322-329. [CrossRef]

251. Sharawy, Z.Z.; Ashour, M.; Abbas, E.; Ashry, O.; Helal, M.; Nazmi, H.; Kelany, M.; Kamel, A.; Hassaan, M.; Rossi, W.; et al. Effects of dietary marine microalgae, Tetraselmis suecica, on production, gene expression, protein markers and bacterial count of Pacific white shrimp Litopenaeus vannamei. Aquac. Res. 2020, 51, 2216-2228. [CrossRef]

252. Rahman, N.A.; Khatoon, H.; Yusuf, N.; Banerjee, S.; Haris, N.A.; Lananan, F.; Tomoyo, K. Tetraselmis chuii biomass as a potential feed additive to improve survival and oxidative stress status of Pacific white-leg shrimp Litopenaeus vannamei postlarvae. Int. Aquat. Res. 2017, 9, 235-247. [CrossRef]

253. Pereira, H.; Sardinha, M.; Santos, T.; Gouveia, L.; Barreira, L.; Dias, J.; Varela, J. Incorporation of defatted microalgal biomass (Tetraselmis sp. CTP4) at the expense of soybean meal as a feed ingredient for juvenile gilthead seabream (Sparus aurata). Algal Res. Biomass Biofuels Bioprod. 2020, 47, 101869. [CrossRef]

254. Messina, M.; Bulfon, C.; Beraldo, P.; Tibaldi, E.; Cardinaletti, G. Intestinal morpho-physiology and innate immune status of European sea bass (Dicentrarchus labrax) in response to diets including a blend of two marine microalgae, Tisochrysis lutea and Tetraselmis suecica. Aquaculture 2019, 500, 660-669. [CrossRef]

255. Kiron, V.; Sørensen, M.; Huntley, M.; Vasanth, G.K.; Gong, Y.Y.; Dahle, D.; Palihawadana, A.M. Defatted biomass of the microalga, Desmodesmus sp., can replace fishmeal in the feeds for Atlantic salmon. Front. Mar. Sci. 2016, 3, 67. [CrossRef]

256. Carvalho, M.; Montero, D.; Torrecillas, S.; Castro, P.; Zamorano, M.J.; Izquierdo, M. Hepatic biochemical, morphological and molecular effects of feeding microalgae and poultry oils to gilthead sea bream (Sparus aurata). Aquaculture 2021, 532, 736073. [CrossRef]

257. Sarker, P.K.; Kapuscinski, A.R.; Vandenberg, G.W.; Proulx, E.; Sitek, A.J. Towards sustainable and ocean-friendly aquafeeds: Evaluating a fish-free feed for rainbow trout (Oncorhynchus mykiss) using three marine microalgae species. Elem. Sci. Anthr. 2020, 8, 404. [CrossRef]

258. Perez-Velazquez, M.; Gatlin, D.M.; Gonzalez-Felix, M.L.; Garcia-Ortega, A.; de Cruz, C.R.; Juarez-Gomez, M.L.; Chen, K.Q. Effect of fishmeal and fish oil replacement by algal meals on biological performance and fatty acid profile of hybrid striped bass (Morone crhysops female $\times$ M. saxatilis male). Aquaculture 2019, 507, 83-90. [CrossRef]

259. Bruce, J.R.; Knight, M.; Parke, M.W. The rearing of oyster larvae on an algal diet. J. Mar. Biol. Assoc. UK 2009, 24, 337-374. [CrossRef]

260. Ryckebosch, E.; Bruneel, C.; Termote-Verhalle, R.; Goiris, K.; Muylaert, K.; Foubert, I. Nutritional evaluation of microalgae oils rich in omega-3 long chain polyunsaturated fatty acids as an alternative for fish oil. Food Chem. 2014, 160, 393-400. [CrossRef]

261. Jusadi, D.; Ekasari, J.; Suprayudi, M.A.; Setiawati, M.; Fauzi, I.A. Potential of underutilized marine organisms for aquaculture feeds. Front. Mar. Sci. 2021, 8, 609471. [CrossRef]

262. Lindsay, G.J.H.; Harris, J.E. Carboxymethylcellulase activity in the digestive tracts of fish. J. Fish Biol. 1980, 16, 219-233. [CrossRef]

263. Archibeque, S.L.; Ettinger, A.; Willson, B.D. Nannochloropsis oculata as a source of animal feed. Acta Agron. Hung. 2009, 57, $245-248$. [CrossRef]

264. Li, X.P.; Liu, J.P.; Chen, G.Y.; Zhang, J.G.; Wang, C.B.; Liu, B. Extraction and purification of eicosapentaenoic acid and docosahexaenoic acid from microalgae: A critical review. Algal Res. Biomass Biofuels Bioprod. 2019, 43, 101619. [CrossRef]

265. Lee, S.Y.; Cho, J.M.; Chang, Y.K.; Oh, Y.K. Cell disruption and lipid extraction for microalgal biorefineries: A review. Bioresour. Technol. 2017, 244, 1317-1328. [CrossRef]

266. Adam, F.; Abert-Vian, M.; Peltier, G.; Chemat, F. "Solvent-free" ultrasound-assisted extraction of lipids from fresh microalgae cells: A green, clean and scalable process. Bioresour. Technol. 2012, 114, 457-465. [CrossRef] 
267. Lee, J.Y.; Yoo, C.; Jun, S.Y.; Ahn, C.Y.; Oh, H.M. Comparison of several methods for effective lipid extraction from microalgae. Bioresour. Technol. 2010, 101, S75-S77. [CrossRef]

268. Goettel, M.; Eing, C.; Gusbeth, C.; Straessner, R.; Frey, W. Pulsed electric field assisted extraction of intracellular valuables from microalgae. Algal Res. Biomass Biofuels Bioprod. 2013, 2, 401-408. [CrossRef]

269. Yoo, G.; Park, W.K.; Kim, C.W.; Choi, Y.E.; Yang, J.W. Direct lipid extraction from wet Chlamydomonas reinhardtii biomass using osmotic shock. Bioresour. Technol. 2012, 123, 717-722. [CrossRef] [PubMed]

270. Zhang, Y.; Kong, X.Y.; Wang, Z.M.; Sun, Y.M.; Zhu, S.N.; Li, L.H.; Lv, P.M. Optimization of enzymatic hydrolysis for effective lipid extraction from microalgae Scenedesmus sp. Renew. Energy 2018, 125, 1049-1057. [CrossRef]

271. Zuorro, A.; Maffei, G.; Lavecchia, R. Optimization of enzyme-assisted lipid extraction from Nannochloropsis microalgae. J. Taiwan Inst. Chem. Eng. 2016, 67, 106-114. [CrossRef]

272. Ryckebosch, E.; Muylaert, K.; Foubert, I. Optimization of an analytical procedure for extraction of lipids from microalgae. J. Am. Oil Chem. Soc. 2012, 89, 189-198. [CrossRef]

273. Sharma, A.K.; Chintala, V.; Ghodke, P.; Prasher, P.; Patel, A. Extraction and purification of PUFA from microbial biomass. In Nutraceutical Fatty Acids from Oleaginous Microalgae; John Wiley and Sons: Hoboken, NJ, USA, 2020; pp. $249-279$.

274. Folch, J.; Lees, M.; Sloane Stanley, G.H. A simple method for the isolation and purification of total lipides from animal tissues. J. Biol. Chem. 1957, 226, 497-509. [CrossRef]

275. Matyash, V.; Liebisch, G.; Kurzchalia, T.V.; Shevchenko, A.; Schwudke, D. Lipid extraction by methyl-tert-butyl ether for high-throughput lipidomics. J. Lipid Res. 2008, 49, 1137-1146. [CrossRef]

276. Patel, A.; Matsakas, L.; Sartaj, K.; Chandra, R. Extraction of lipids from algae using supercritical carbon dioxide. In Green Sustainable Process for Chemical and Environmental Engineering and Science; Elsevier: Amsterdam, The Netherlands, 2020; pp. 17-39.

277. Daintree, L.S.; Kordikowski, A.; York, P. Separation processes for organic molecules using SCF Technologies. Adv. Drug Deliv. Rev. 2008, 60, 351-372. [CrossRef] [PubMed]

278. Sahena, F.; Zaidul, I.S.M.; Jinap, S.; Karim, A.A.; Abbas, K.A.; Norulaini, N.A.N.; Omar, A.K.M. Application of supercritical CO 2 in lipid extraction-A review. J. Food Eng. 2009, 95, 240-253. [CrossRef]

279. Mendes, A.; da Silva, T.L.; Reis, A. DHA concentration and purification from the marine heterotrophic microalga Crypthecodinium cohnii CCMP 316 by winterization and urea complexation. Food Technol. Biotechnol. 2007, 45, 38-44.

280. Ryckebosch, E.; Bruneel, C.; Termote-Verhalle, R.; Lemahieu, C.; Muylaert, K.; Van Durme, J.; Goiris, K.; Foubert, I. Stability of Omega-3 LC-PUFA-rich photoautotrophic microalgal oils compared to commercially available Omega-3 LC-PUFA oils. J. Agric. Food Chem. 2013, 61, 10145-10155. [CrossRef] [PubMed]

281. Chen, L.; Liu, T.Z.; Zhang, W.; Chen, X.L.; Wang, J.F. Biodiesel production from algae oil high in free fatty acids by two-step catalytic conversion. Bioresour. Technol. 2012, 111, 208-214. [CrossRef]

282. Gatrell, S.K.; Kim, J.; Derksen, T.J.; O’Neil, E.V.; Lei, X.G. Creating omega-3 fatty-acid-enriched chicken using defatted green microalgal biomass. J. Agric. Food Chem. 2015, 63, 9315-9322. [CrossRef]

283. Camacho, F.; Macedo, A.; Malcata, F. Potential industrial applications and commercialization of microalgae in the functional food and feed industries: A short review. Mar. Drugs 2019, 17, 312. [CrossRef] 